The Production of Oil From

Intermountain West Tar Sands Deposits

By: Joseph M. Glassett

Joel A. Glassett

Final Report

Co. No.: S0241129

Eyring Research Institute

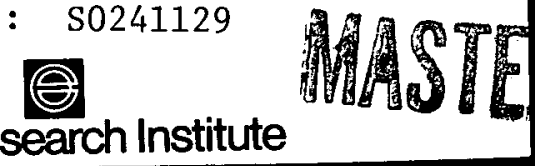




\section{DISCLAIMER}

This report was prepared as an account of work sponsored by an agency of the United States Government. Neither the United States Government nor any agency Thereof, nor any of their employees, makes any warranty, express or implied, or assumes any legal liability or responsibility for the accuracy, completeness, or usefulness of any information, apparatus, product, or process disclosed, or represents that its use would not infringe privately owned rights. Reference herein to any specific commercial product, process, or service by trade name, trademark, manufacturer, or otherwise does not necessarily constitute or imply its endorsement, recommendation, or favoring by the United States Government or any agency thereof. The views and opinions of authors expressed herein do not necessarily state or reflect those of the United States Government or any agency thereof. 


\section{DISCLAIMER}

Portions of this document may be illegible in electronic image products. Images are produced from the best available original document. 


\title{
THE PRODUCTION OF OIL FROM INTERMOUNTAIN WEST TAR SANDS DEPOSITS
}

\author{
By \\ Joseph M. Giassett \\ and \\ Joel A. Glassett \\ Final Report To \\ United States Department of the Interior \\ Bureau of Mines \\ Contract No. SO241129
}

March 1976

The views and conclusions contained in this document are those of the authors and should not be interpreted as necessarily representing the official policies or recommendations of the Interior Departments Bureau of Mines of the U.S. Government. - No inventions or patents have resulted from work on this contract.

EYRING RESEARCH INSTITUTE

9502423

$1455 \mathrm{~W} .820 \mathrm{~N}$.

Provo, Utah 84601

(801) $\quad 375-2434$ 
TABLE OF CONTENTS

Page

Abstract . . . . . . . . . . . . . . . . . 1

Introduction . . . . . . . . . . . . . . . . . . . I

Acknowledgment . . . . . . . . . . . . . . . . 2

Location of Largest Deposits . . . . . . . . . . . 2

Surface Mining . . . . . . . . . . . . . . . . . 4

Chemical Processing. . . . . . . . . . . . . . . .ll

Environmental Aspects. . . . . . . . . . . . . . .15

Economics. . . . . . . . . . . . . . . . . . 18

Comparison of Utah and Athabasca Tar Sand Deposits . . . 20

Asphalt Ridge. . . . . . . . . . . . . . . . 24

Geology . . . . . . . . . . . . . . . . . .24

Surface Mining. . . . . . . . . . . . . . . . 24

Chemical Processing.. . . . . . . . . . . . . .30

Environmental Aspects . . . . . . . . . . . . . .34

Conclusions . . . . . . . . . . . . . . . 36

Circle Cliffs. . . . . . . . . . . . . . . . 37

Geology . . . . . . . . . . . . . . . . .37

Surface Mining. . . . . . . . . . . . . . . .37

Chemical Processing . . . . . . . . . . . . . .40

Environmental Aspects... . . . . . . . . . . . .4I

Conclusions . . . . . . . . . . . . . . . .41

Hill Creek . . . . . . . . . . . . . . . .42

Geology . . . . . . . . . . . . . . . .42

Surface Mining. . . . . . . . . . . . . . . .42

Chemical Processing . . . . . . . . . . . . . . .44

Environmental Aspects ................. .44

Conclusions . . . . . . . . . . . . . . . . . .44 
Table of Contents (cont.)

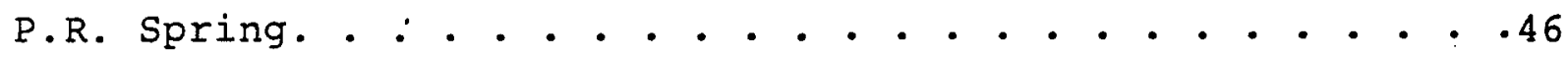

Geology . . . . . . . . . . . . . . . . . . . 46

Surface Mining. . . . . . . . . . . . . . . .48

Chemical Processing . . . . . . . . . . . . . .48

Environmental Aspects . . . . . . . . . . . . . . . . . . .

Conclusions... . . . . . . . . . . . . . . . 51

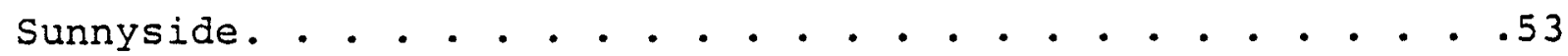

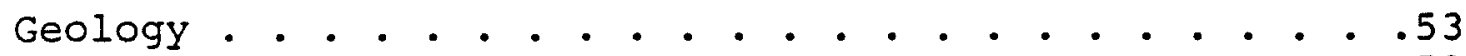

Surface Mining. . . . . . . . . . . . . . . . . . 53

Chemical Processing . . . . . . . . . . . . . 58

Environmental Aspects . . . . . . . . . . . . . . . . . . . .

Conclusions . . . . . . . . . . . . . . . . . . . . . . . . . . .

Tar Sand Triangle. . . . . . . . . . . . . . . . . . . . . . 60

Geology . . . . . . . . . . . . . . . . . . . . . . . . . .

Surface Mining. . . . . . . . . . . . . . . . 61

Chemical Processing . . . . . . . . . . . . . 62

Environmental Aspects . . . . . . . . . . . . .62

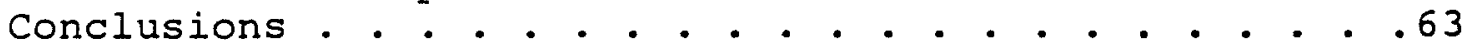

Conclusions. . . . . . . . . . . . . . . . . . . . . . . . . . . . .

Research Recommendations . . . . . . . . . . . . . . 69

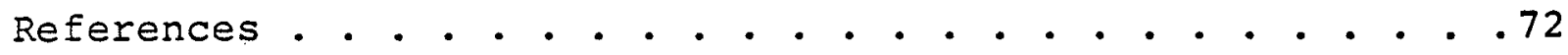

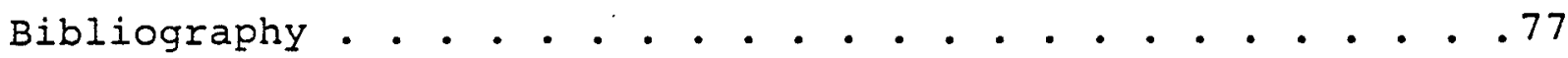




\section{LIST OF FIGURES}

Figure

Page

1. Northeastern Utah Tar Sand Deposits. . . . . . . . . . 3

2. Southeastern Utah Tar Sand Deposits. . . . . . . . . . 5

3. Flow Diagram of Cities Service Process . . . . . . . 13

4. Geologic Cross Profile - Asphalt Ridge Area. • . • . 25

5. Vicinity Map - Proposed Bituminous Sand Mine . . . . . 27

6. Location - Proposed Bituminous Sand Mine . . . . . . 28

7. Location - Sohio Coreholes . . . . . . . . . . . 31

8. Diagrammatic Cross Section - Circle Cliffs Uplift. • . 38

9. Circle Cliffs. . . . . . . . . . . . . . . . 39

10. Hill Creek Overlay . . . . . . . . . . . . . . 43

11. Bituminous Sandstone Deposits Near Sunnyside . . . . . 55

12. Geologic Map of Sunnyside Quarry Area. . . . . . . . 56

\section{LIST OF TABLES}

Table

I. Surface Mining Variables . . . . . . . . . . . . . . . 4

II. Tar Sand Characteristics . . . . . . . . . . . . 8

III. Sohio Corehole Analyses. . . . . . . . . . . . . . 29

IV. Asphalt Ridge Tar Sand and Oil Analyses. . . . . . . . . 32

V. Tertiary Formations of the Southeastern Uinta Basin. . . 47

VI. P.R. Spring Tar Sand and Oil Analyses. . . . . . . . . . 48 
List of Tables (cont.)

VII. Comparison of P.R. Spring and Athabasca Tar Sands. . . 49

VIII. Distillation Data for P.R. Spring Bitumens . . • . • 50

IX. Surface Mining Variables . . . . . . . . . . . . . 65 


\author{
THE PRODUCTION OF OIL FROM INTERMOUNTAIN \\ WEST TAR SAIJDS DEPOSITS \\ by
}

Josepin. M. Glassett* and Joel A. Glassett**

\begin{abstract}
Six tar sand deposits in the Intermountain west, each containing more than one billion barrels of oil in place, are identified. All of these deposits are in eastern utan and contain a total of twenty-eight billion barrels of oil. The names of the six deposits arranged in descending order of desirability for large scale surface mining oil recovery operations are as follows; Sunnyside, Tar Sand Triangle, Aspialt Ridge, P.R. Spring, Circle Cliffs, and Hill creek. An overview of each deposit is presented including geology, surface mining variables, chemical processing variables, environmental aspects, and economics. A comparison of Utah tar sands and Athabasca, Alberta, Canada tar sands is also presented.
\end{abstract}

\title{
INTRODUCTION
}

There is an urgent need for orderly development of additional sources of hydrocarbons if the national goal of "energy independence" is to be reacned. The tar sand deposits of the intermountain region of the western United States have an estimated reserve of more than twenty-eignt (28) billion barrels of oil in place. Most of the deposits are located in eastern Utah. Although this resource is only a small fraction of the total U.S. oil requirement, it could be an important source of nydrocarbons on a regional basis.

The hydrocarbons within the tar sands resemble normal crude oil except that due to abnormally hign viscosity, they cannot ve produced in their native state by ordinary oil field production teciniques. Past sporatic efforts by industry to develop oil recovery operations have all ended in failure due to the nigner cost of producing oil from tar sands compared with other oil sources existent at that time. Recent changes in oil price structure plus successful development of Canadian tar sand deposits give nope that a tar sand industry may be possible in eastern Utah.

* Associate Professor of Chemical Engineering at Brigham

* * Young University 
The Bureau of Mines is conducting research on the surface mining of tar sands with the following objectives: (1) To identify and characterize the tar sand deposits of the Intermountain West; (2) To provide an evaluation of surface mining and processing of the larger deposits; and (3) To provide information on research that may be conducted to speed up the development of the tar sand resource.

This particular study has been limited to the six tar sand deposits that are known to contain more than one billion barrels of oil in place. Recoverable reserves of this magnitude would supply a 100,000 barrel per day plant for a period of at least twenty years. It has been assumed that a 100,000 barrel per day plant would be the minimum economical plant capacity for oil extraction, upgrading, and refining operations.

The Utah Geological and Mineral Survey (UGMS), a division of Utah's Department of Natural Resources, has identified more than fifty tar sand deposits in Utah containing a total of more than twenty-eight billion barrels of oil in place. This oil reserve represents more than ninety percent of the known tar sand oil in the United States and is a larger oil resource tinan the Alaskan North Slope. While this represents only a small fraction of the oil contained in the 700 billion barrel Athabasca reserves of tar sand oil in Alberta, Canada, the recovery of a significant portion of this oil reserve would contribute greatly toward the future oil needs of the Intermountain Region.

\section{ACKNOWLEDGMENT}

Eyring Research Institute wishes to express appreciation to those who contributed information to this study of the tar sands of the Intermountain West. Only a few of those who contributed data are mentioned in the references.

\section{LOCATION OF LARGEST DEPOSITS}

UGMS indicates that only six of the known tar sand deposits in Utah are individually larger than one billion barrels of estimated oil in place. All six of these large deposits are in eastern Utah. Four (if) these are shown in Figure 1 which is a map of northeastern Utah. (1) The four major deposits shown in this figure are as follows: (1) Asphalt Ridge, southwest of Vernal in Uintah county, containing about 1.1 billion barrels of oil in place; (2) Sunnyside, northeast of Sunnyside in Carbon county, containing 3.5 to 4.0 billion barrels of Oil; (3) Hill Creek in Uintah County, containing 1.2 billion barrels of oil; and (4) P.R. Springs in Uintah and Grand Counties, containing 4.0 to 4.5 billion barrels of oil in place. The black areas on the map show where tine tar 


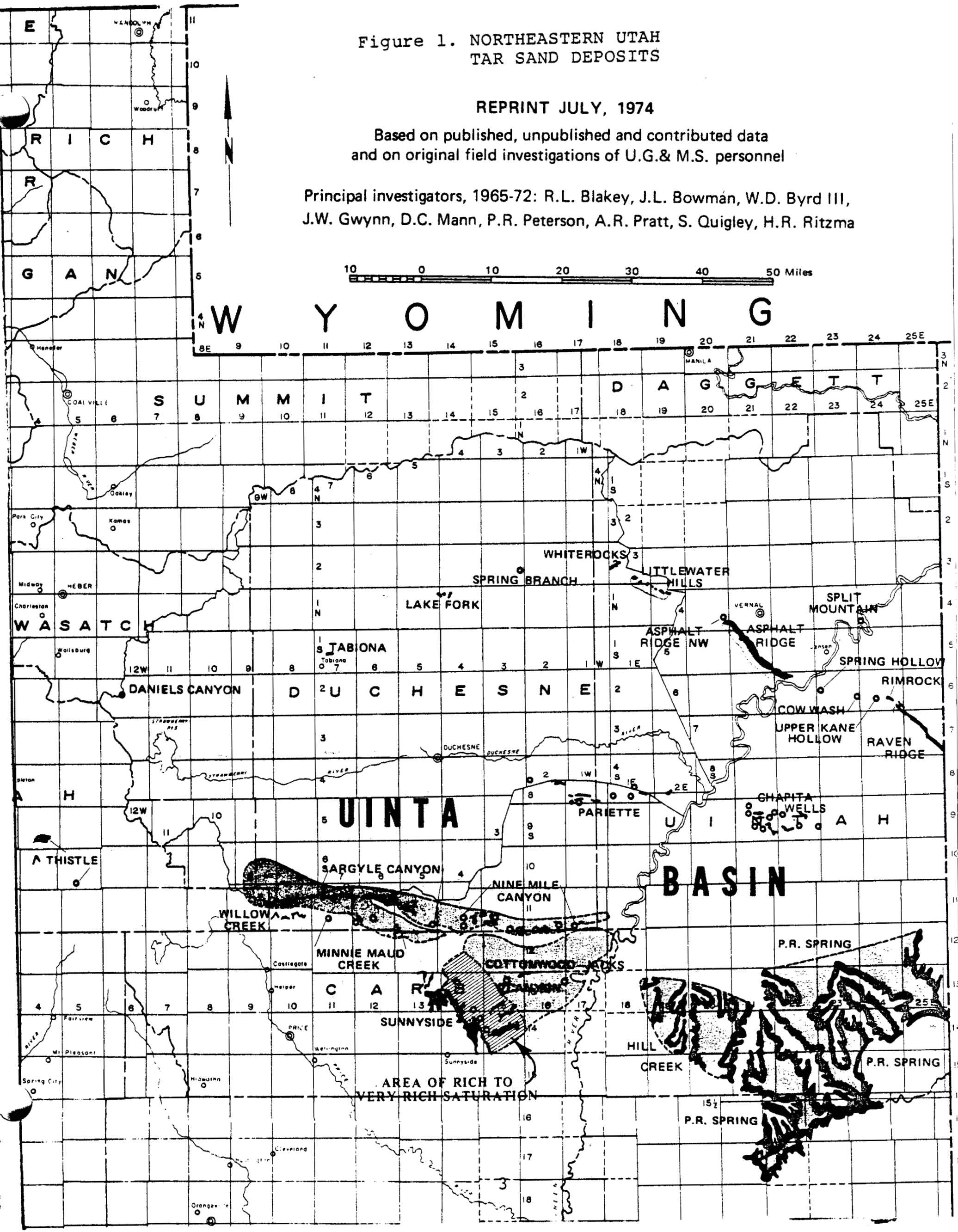


sands outcrop or are exposed to the atmosphere. The white areas penetrating the P.R. Spring and Hill Creek deposits mark canyons that have been eroded completely through the tar sand ore bodies. These four major deposits were formed during the Tertiary Age more than forty million years ago. The large, richly organic lake Uinta covered the depression now known as the Uinta Basin for about twenty million years. Lake Uinta resulted in the production of tar sand, crude oil, oil shale, gilsonite, and other fossil energy materials.

Figure 2 is a map (1) of the southeastern corner of Utah showing the other two of the six large tar sand deposits. As indicated on the map, they are as follows: (5) Tar Sand Triangle in Garfield and Wayne Counties, which contains 12.5 to 16 billion barrels of oil; and (6) Circle cliffs in Garfield county, containing 1.3 billion barrels of oil.

The tar sand in these two deposits occurs in older rocks that are more than 200 million years old. Most of the oil in the Tar Sand Triangle occurs in the Permian White Rim Sandstone. The Circle cliffs deposits occur mostly in Triassic sandstones.

\section{SURFACE MINING}

All of the six major Utan tar sand deposits lie in rough, mountainous terrain. As a consequence of the rough terrain, one can expect a wide variation in overburden thickness. Uniform pay zones seldom occur since during their formation the oil probably migrated into the porous sandstone in which it is found. This erratic behavior of tar sand deposits further complicates the identification of areas rich enough in oil saturation and with the minimum of overburden necessary for economical mining.

Table I contains data obtained from UGMS Map $33^{(1)}$ on the area in square miles, number of pay zones, pay thickness in feet, and the oil reserve of the six major Utah deposits. The overburden thickness at each deposit varies from zero at the outcrop to more than 500 feet.

Table I

SURFACE MINING VARIABLES

\begin{tabular}{|l|c|c|c|c|}
\hline \multicolumn{1}{|c|}{ Deposit } & Area & $\begin{array}{c}\text { Number of } \\
\text { Say Mones }\end{array}$ & $\begin{array}{c}\text { Pay Thickness } \\
\text { Feet }\end{array}$ & $\begin{array}{c}\text { Oil Reserve } \\
\text { Billion Barrels }\end{array}$ \\
\hline Asphalt Ridge & 20 to 25 & 2 to 5 & 10 to 135 & 1.05 \\
Hill Creek & 115 to 125 & 1 to 3 & 5 to 35 & 1.16 \\
P.R. Spring & 240 to 270 & 2 to 6 & 10 to 80 & 4.0 to 4.5 \\
Sunnyside & 35 to 90 & 3 to 12 & 15 to 550 & 3.5 to 4.0 \\
Circle Cliffs & 28 & 1 to 3 & 5 to 310 & 1.31 \\
Tar Sand Triangle & 200 to 230 & 1 to 2 & 5 to 300 & 16 \\
\hline
\end{tabular}




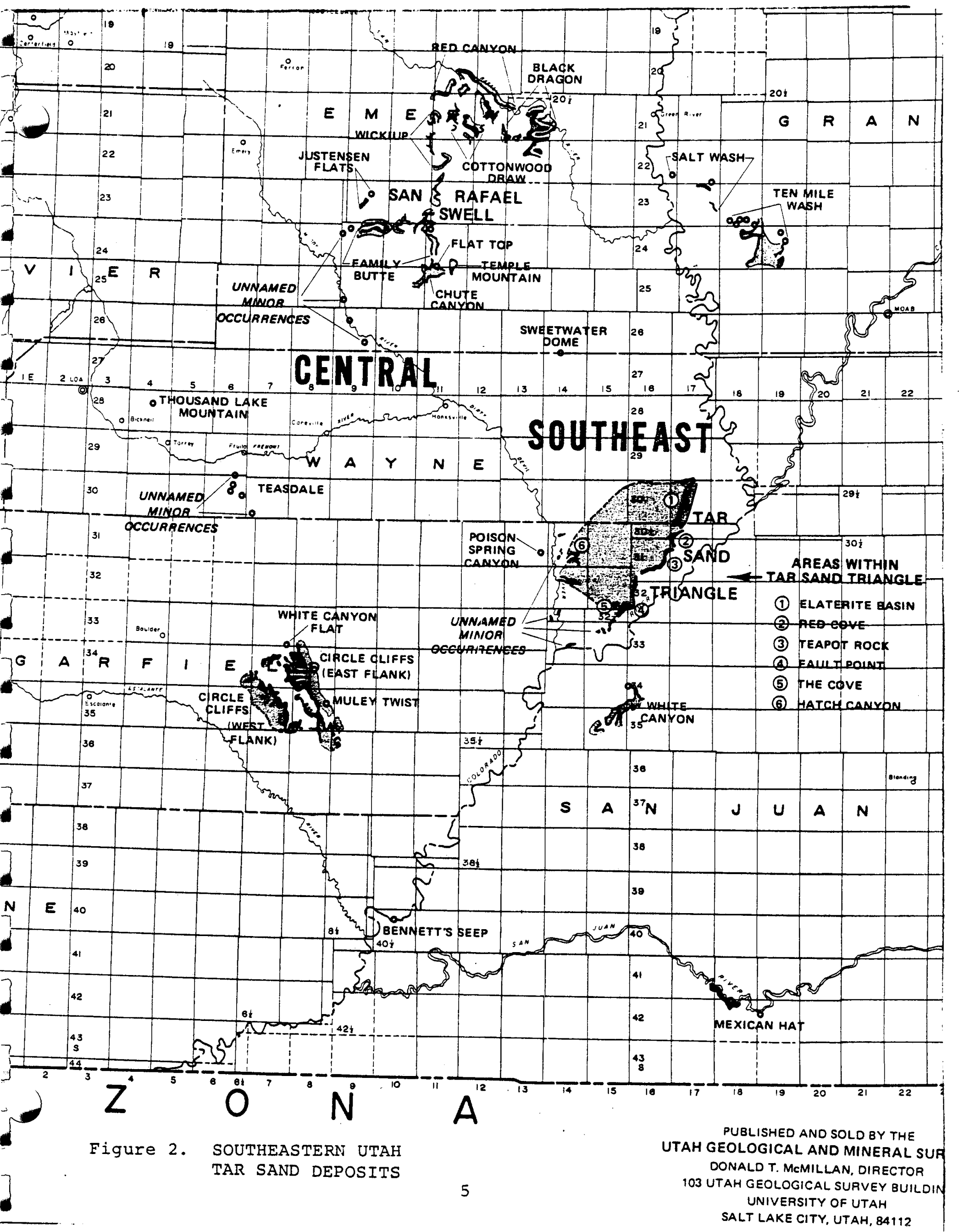


The oil reserve values in Table I refer to gross oil in place and include the total of measured, indicated, and inferred/ conjectual categories of reserves. Reserves in each of these categories were calculated based on the reliability of the data available on each tar sand deposit. Oil reserve data calculations made by UGMS were based on core-drilling data, field mapping, field inspection, and published descriptions. "In most areas the deposit was assumed to persist for at least 1,320 feet back of the outcrop or for one mile where field mapping or core data indicated conditions of blanket saturation."

Probably the most important variable in surface mining is the overburden to pay ratio. Mining must stop when the maximum economical overburden to pay ratio is reached since beyond that limit financial losses result instead of profits. Overburden to pay ratios in the surface mining of tar sand will be much lower than in the surface mining of coal since the value of a ton of tar sand is much lower than the value of a ton of coal. The fundamental reason for this difference in value is that tar sand contains only about ten percent oil whereas coal usually contains more than ninety percent hydrocarbon. Maximum overburden to pay ratios for the surface mining of tar sand in Utah are expected to be less than unity until the value of oil increases drastically.

Maximum economical overburden to pay ratio will vary with the oil content of the tar sand ore. The true economic yardstick in tar sand surface mining is the barrels of bitumen extracted per cubic yard of material (overburden plus ore) moved. In Athabasca, Alberta, Canada mines are planned where oil content is twelve weight percent or more and the average overburden to pay ratio is 0.5 or less. If the oil content of the pay zone drops below eight percent at the GCOS mine the ore is rejected (not mined). Decreasing the ore cut off grade below eight percent increases mining costs and decreases the oil producing capacity of an existing extraction plant.

Before a surface mine can be planned the ore body must be defined. This resource evaluation work is usually done in logical steps. When outcrop data indicate that a large and favorable ore body may exist a more thorough geological study needs to be made. Stratigraphic sectioning of the outcrops will help to define the ore body in a preliminary way. If such a study indicates the existence of a good ore body core drilling should begin. During the first core drilling program two to four cores should be drilled per square mile (per section). This core spacing is adequate to decide whether to reject the mine site or to investigate further. Several core holes per section can give significant information relative to overburden tnickness, pay thickness, degree of consolidation of overburden and pay., percent of oil saturation, the characteristics of the oil, and 
the presence of excessive silt and clay which might seriously interfere with processing. If preliminary core drilling is favorable the core spacing should be decreased to from ten to twenty core holes per section. This tignter core spacing is needed to establish the ore body continuity, the extent of variations, and to accurately determine the maximum extraction plant capacity. If large areas, or bands, of low grade ore or barren material must be rejected plant capacity, mining capacity, and mining plan will be affected. Selective mining is more expensive than the mining of a uniform and continuous pay zone. Finally, a coring program utilizing forty to sixty cores per section with sample analysis of every five or ten feet of core may be required for operational control of an operating mine.

Much additional resource evaluation work needs to be done on the six largest tar sand deposits in Utah. The location of outcrops is probably quite complete. Some mapping, stratigraphic sectioning, and core drilling has been done but more is needed. Resource evaluation work has been greatest at the P.R. Spring and Asphalt Ridge deposits. Considerable evaluation work remains to be done at the other four large deposits.

There are pronounced differences in the physical properties and appearance of the different tar sand deposits and even of different areas within a single deposit. For example, the Asphalt Ridge deposit is highly oil saturated. The sandstone is not firmly consolidated, having the appearance that the bitumen holds the sand grains together. It resembles the asphalt surfacing of a road on a hot day in its consistency. This material is presently being surface mined using ripper blades on a caterpillar tractor. Drilling and blasting are unnecessary. By contrast, the bitumen of the Tar Sand Triangle occurs in fine-grained, highly consolidated sandstone. Drilling and blasting both the overburden and the ore body $55 j 11$ be required at this deposit. Cecil $Q$. Cupps, et al $(55)$ present a summary of some average properties of the six largest Utah deposits in Table II. These data indicate that the large Utan deposits are less than fifty percent saturated with oil, have low water content, and have compressive strengths characteristic of consolidated rocks. In addition to the data in Table II these writers indicate that the Asphalt Ridge deposit samples had an average compressive strength of 1,632 psi after oil extraction. The degree of consolidation of overburden and pay is a good indication of whether or not the material should be drilled and blasted prior to excavation.

In general, it is expected that drilling and blasting will be needed at each of the deposits with the possible exception of the Asphalt Ridge deposit. 
Table II

TAR SAND CHARACTERISTICS

\begin{tabular}{|c|c|c|c|c|c|c|c|}
\hline Deposit & \multicolumn{2}{|c|}{$\begin{array}{l}\text { Samples } \\
\text { No. Typel/ }\end{array}$} & $\begin{array}{c}\text { Porosity, } \\
8 \text { P.V. }\end{array}$ & $\begin{array}{c}\text { Permea- } \\
\text { bility, } \\
\text { ma }\end{array}$ & $\begin{array}{l}\text { Bitumen } \\
\text { sat. } \\
\text { \& P.V. }\end{array}$ & $\begin{array}{l}\text { Water } \\
\text { sat. .' } \\
\text { \& P.V. }\end{array}$ & $\begin{array}{c}\text { Compressive } \\
\text { strength, } \\
\text { psi. }\end{array}$ \\
\hline Asphalt Ridge & 120 & $\mathrm{C}$ & 19.6 & 497 & 51.4 & 2.7 & 2,491 \\
\hline Circle Cliffs & 6 & C & 12.3 & 228 & 17.7 & - & - \\
\hline Hill Creek & 203 & C & 20.2 & 325 & 29.7 & 2.1 & 6,555 \\
\hline $\begin{array}{l}\text { N.W. Asphalt } \\
\text { Ridge }\end{array}$ & 1,087 & $\mathrm{C}$ & 22.8 & 603 & 45.2 & 20.2 & 1,598 \\
\hline P.R. Spring & 1,038 & C & 25.0 & 1,510 & 42.5 & 3.0 & 4,784 \\
\hline Sunnyside & 129 & C & 21.3 & 729 & 44.8 & $-\infty$ & 7,805 \\
\hline $\begin{array}{l}\text { Tar Sand } \\
\text { Triangle }\end{array}$ & $\begin{array}{l}29 \\
14\end{array}$ & $\begin{array}{l}S \\
C\end{array}$ & $\begin{array}{l}20.0 \\
19.7\end{array}$ & $\begin{array}{l}207 \\
788\end{array}$ & $\begin{array}{l}6.32 \\
70.7\end{array}$ & 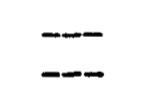 & $\begin{array}{c}3,242 \\
--\end{array}$ \\
\hline$\frac{1 /}{2} \mathrm{~S}=\operatorname{Surf}$ & & t & & & & & \\
\hline
\end{tabular}

The magnitude of the surface mining operation required to supply tar sand feed to a 100,000 barrel per day oil extraction plant almost boggles the mind. If one assumes an average oil content of twenty gallons of oil per cubic yard of tar sand and complete oil recovery, 210,000 cubic yards of pay would have to be mined per day. If the tar sand weighs 3,500 pounds per cubic yard then 368,000 tons per day must be mined. Such a mining operation is about eighty-five percent of the size of the mining operation of the Kennecott Copper corporation at their Bingham Canyon mine in Utah. The Kennecott operation is the largest surface mining operation in the world.

If significant quantities of overburden must be removed or if oil recovery efficiency is less than eighty-five percent, the tar sand mining operation would be larger than the Kennecott open pit mining operation.

To assist the reader in the conception of a 100,000 barrel of oil per day tar sand mining operation, the following data (2) relative to Kennecott Copper Corporation's Bingham Canyon mine are presented. 
Through December 1974, Kennecott has milled 1,313,988,300 tons of ore, removed 2,281,124,089 tons of waste, and produced $10,711,436$ tons of copper. The mine is the largest single mining operation ever undertaken and the largest man-made excavation in the world. The excavation covers 1800 acres, is 2.25 miles wide at the top, and nearly one-half mile deep. The mine has fifty-five benches which vary in height from forty to fifty feet, and in width from thirty-five to 125 feet. Twenty-one of the benches are used for hauling ore by rail over 100 miles of track in the mine. Thirty-four of the benches are used for hauling waste by truck to a huge canyon disposal area.

Current KCC operations include the daily goal of mining 108,000 tons of ore and 324,500 tons of waste for a stripping ratio of 2.98. To accomplish this monumental task, eighteen rotary drilis are in service, thirty-seven electric shovels naving a total capacity of 336 cubic yards are in service, sixty-two bcomotives having a total capacity of 5,600 tons are in service, and ninety-seven trucks having a total capacity of 9,700 tons are in service. About 4.3 tons of ore and waste are moved per pound of explosive and 97,000 pounds of explosives are used per day.

Of the various possible surface mining methods; namely, area mining, contour mining, open-pit mining, mountain-top removal, and auger mining, the method which will be used the most extensively for Utah tar sand mining will be mountain-top removal. The six large Utah deposits all lie in mountainous topography. Typically the pay zones are exposed in outcrops on both sides of a mountain. Where overburden to pay ratio is not too great, for example, at the sunnyside deposit, mining can best be accomplished by removing the mountain-top and filling nearby canyons with overburden and clean process sand. Reclaimed areas will be more nearly level than the original topography and revegetation will be easier than if the pre-mined contours were strictly preserved. Open-pit mining may be possible in areas where a thick pay zone happens to occur near the top of a canyon. Few, if any, areas are likely to be found that are level enough for area mining. After the best mountain-top removal and open-pit areas are mined it may become economical to employ contour mining where overburden thickness becomes prohibitive. Auger mining can be utilized along with contour mining. The writers estimate that less than twenty percent of the known oil reserves of the six large deposits can be surface mined. This percentage will be highest for the sunnyside and Circle cliffs deposits and lowest for the Asphalt Ridge and Tar Sand Triangle deposits.

Surface mining equipment that may be considered in the mining of tar sand includes draglines, power shovels, front-end loaders, dozers, bucket wheel excavators, scrapers, trucks, railroad cars, 
and conveyor belts. Factors which affect the choice of equipment for a particular mining plan include the thickness of the overburden and pay, the degree of consolidation or characteristics of the overburden and pay, the transport distance, the machine support characteristics of the overburden and pay, and the mobility, flexibility, production capability and segregation capability of the equipment. In general, large equipment is more economical to operate; however, equipment size limitations may be encountered when mining tar sand since the large deposits are all in mountainous terrain.

Draglines will be favored over other equipment for overburden removal since they minimize or eliminate overburden transportation cost, have a long reach with boom lengths up to 360 feet, can operate with a high highwall hence may require less advance stripping, and have greater flexibility and maneuverability than shovels or bucketwheel excavators. Draglines do not interfere with operations in the pit since they operate from a working bench above the pay zone. Draglines have the disadvantages of lack of visibility of the highwall, a high instantaneous power demand while filling the bucket, critical bank stability, and may produce large lumps which are difficult to reclaim.

Bucketwheel excavators are not likely to be used in mining Utah tar sand deposits since they require a working floor having a grade of five percent or less. Most of the Utah tar sand pay zones dip more than five percent and do not lend themselves to bucketwheel excavator area mining. Other disadvantages of the bucketwheel excavator include the need for and the cost of a transportation system for overburden and reject material, a bench height limitation of about one hundred feet, and the difficulty in mining material containing boulders. Bucketwheel mining has the advantages of mine face visability, good mining selectivity, proven technology in Athabasca, and the elimination of double handling of material.

Shovels may not be adequate if there is a load bearing problem since they operate from the surface of the pay to move overburden. Shovels do not require the working bench of the dragline but they require a much shorter highwall than the dragline. Shovels are used instead of draglines if the overburden must be transported away from the mine.

If overburden thickness is less than thirty feet front-end loaders, dozers, and scrapers may be considered. Conventional scrapers are not adequate for mining tar sand ore but some rubber-tired front-end loaders are adequate.

The following factors must be considered in the selection of mining transportation equipment: (1) magnitude of the operation, 
(2) haul distance, (3) destination of the material, (4) soil stability, (5) climate, (6) topography and grades, and (7) the availability of construction material for roads. Transoortation equipment to be considered includes trucks, railroad cars, and conveyors. Trucks may be favored for short hauls or for intermittent operations. They are very flexible and can be utilized in irregular excavations or where selective mining is required. Trucks as large as 200 ton capacity are available with drive motors in each rear wheel. Haul roads for trucks may be constructed of lean reject tar sand. Blacktop highways contain about six percent asphalt. Tar sand containing less than six percent bitumen will probably be too lean for economical processing, but will be excellent for road building. Truck and shovel sizes should be matched so that from three to five dipper loads will fill the truck.

Railroad cars are seldom used except for very long hauls. They require a good road bed, and good track maintenance. Bearing pressures and the freezing or sticking of tar sand in the cars may be a serious problem.

Conveyors have the advantages of continuous operation and the ability to handle large volumes. A high speed conveyor can handle up to 20,000 tons of materials per hour. Conveyors lack flexibility. If the conveyor must be stopped, then mining stops also. Conveyors must be matched to the digging equipment. They operate very well with bucketwheel excavators and can be used with other mining equipment by using conveyor loading devices. Care must be taken to avoid putting large lumps of material on conveyors or maintenance may become excessive.

\section{CHEMICAI PROCESSING}

After tar sand has been surface mined, there are a number of alternative methods of separating the bitumen from the mineral matter. These methods may be classified as thermal, cold water, hot water, solvent, and a combination of solvent and water. Thermal methods require temperatures high enough to cause the hydrocarbon components of the bitumen to flow readily, vaporize some of them, or to coke the bitumen by thermal or catalytic cracking. Coking processes may be similar in many respects to the retorting of oil shale. Dr. Alex G. Oblad, (3) who heads a research team at the University of Utah, is working on the thermal extraction of tar sand using a fluidized bed. Particular emphasis is being placed on the development of techniques to recover heat from the hot spent sand after residual coke has been burned from it. They also are studying hot water and solvent extraction methods in stirred reactors. 
Fairbrim Company, a contraction of Fairbanks and Brimhall, has a combination cold water and solvent extractor. Their pilot plant extractor uses a horizontal rectangular tank eight feet wide, forty feet long, and four feet deep. The tar sand ore is crushed, saturated with a solvent, and fed into the horizontal tank containing cold chemically treated water. Mr. John B. Fairbanks, Jr., President of Fairbrim, stated during the Sohio petroleum Corporation mining application hearing in Vernal, Utah on 28 August 1974, that if the water were spilled, the chemical contained in it would neither enhance nor harm plant growth. Gentle agitation is provided by the action of a rake mechanism that drags the sand along the bottom of the tank. The oil-solvent mixture separates from the tar sand, rises to the surface of the water, and is skimmed from the top of the extractor. The cleaned sand is dragged up a ramp and emerges from the water bath. The bitumen production capacity of this extractor is claimed to be 200 barrels per day at a cost of approximately three dollars per barrel at $1000 \mathrm{~B} / \mathrm{D}$ capacity. This Fairbrim extractor has been in use at a tar sand deposit in Kyrock, Kentucky near Mammoth Cave, but is presently shut down while a feasibility study is being made relative to larger scale production.

Arizona Fuels Corporation has developed a combination solvent and hot water extraction unit. Mr. Eugene Dalton, President of Arizona Fuels Corporation, describes(4) their process as follows: The mined tar sand is dumped into a conditioning tank containing a heated hydrocarbon solvent. The sand/solvent mixture is then slurried to the top of a columnar vessel which is six feet in diameter and fifty feet high containing heated solvent. As the sand grains fall through the solvent eighty to ninety percent of the bitumen is extracted. The sand grains then pass through a warm caustic water solution which removes the remaining bitumen. The solvent bitumen mixture is witharawn from the column in a continuous process. Most of the mixture is transported by truck to a refinery and the remainder is returned to the solvent heater with make-up solvent. After the sand falls through the entire column it is removed at the bottom and the clean sand is slurried with cold water to the reclamation area. A 600-horsepower steam boiler is used for all heating requirements. The capacity of the extraction unit is expected to be 1,000 barrels per day under continuous operation.

By 1961, Cities Service Athabasca Inc. had developed a laboratory scale anhydrous solvent extraction process for extracting bitumen from Athasbasça tar sand, the flowsheet of which is illustrated in Figure 3. (5) A key element of the process is the gentle mixing of recycle solvent and tar sand for about five minutes. It is claimed (5) that if this is done properly, the bitumen between the sand grains and the bitumen coating the water-clay 


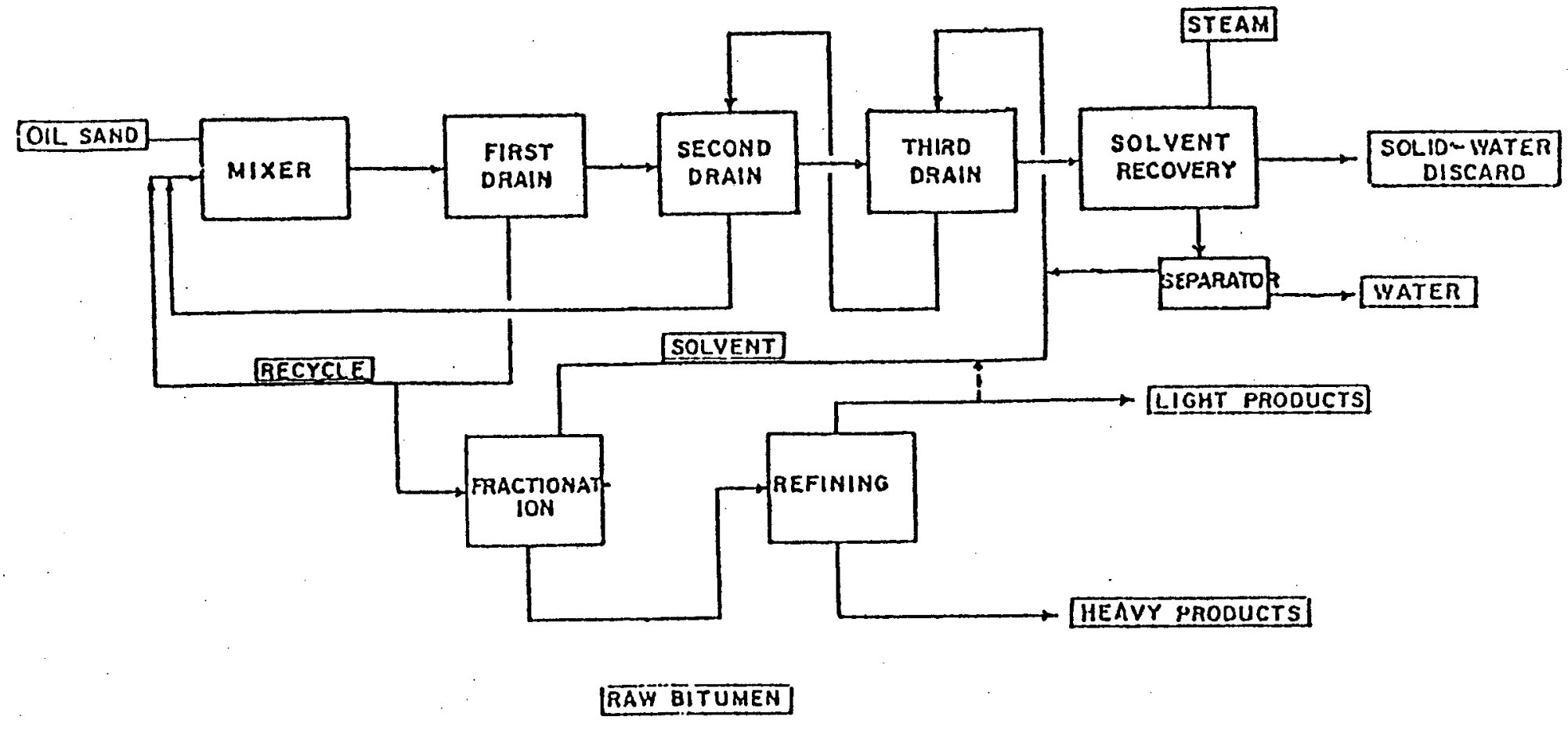

Figure 3. Flow Diagram of Cities Service Process 
envelope around the sand grains will be removed without breaking the water-clay envelope. The sand is then subjected to a threestage countercurrent solvent wash which Camp(6) describes as a draining operation. Drain rates of $10 \mathrm{gal} / \mathrm{min} / \mathrm{sq}$. ft. were obtained with a differential pressure of fifteen inches of mercury. If water was added to the draining beds, they quickly became plugged due to the movement of silt and clay from the water-clay envelopes around the sand grains. Several methods were tried to recover solvent from the spent sand. Solvent was recovered from the bitumen by distillation. Camp $(6)$ presents a material balance for the process which shows ninetythree percent bitumen recovery and one percent solvent loss.

Guardian Chemical Corporation(7) of Hauppauge, Long Island, New York, has a 400-pound per hour pilot plant that uses water and a modified form of Polycomplex. Guardian claims that their process recycles chemicals and water used and has low energy consumption and capital equipment cost. A dilute solution of Polycomplex $A-11$ at $95^{\circ} \mathrm{F}$ is mixed with tar sand in rotary extraction drums where three separate products form. The oil product on top is skimmed off. The water containing most of the complex is recycled, and the clean wet sand bottoms, after an additional wash, are discarded. Guardian claims ninety-five percent oil recovery and predicts a commercial process cost of $\$ 5.00$ per barrel. Guardian has plans to build a pilot plant in Edmonton, Alberta, Canada.

Minerals Research Corporation of ogden, Utah (8) has built and operated a small solvent extractor which utilizes a continuous moving porous screen or conveyor belt for moving the tar sand. Solvent sprays above the belt wash the bitumen from the sand in a counter-current manner. Extractor tests indicate a ninetynine percent bitumen recovery. MRC's U.S. Patent $3,856,474$ issued 24 December 1974, suggests the use of one of several chlorinated hydrocarbon solvents because they have low boiling points, low heats of vaporization, low specific heats, and are not flammable. Distillation is used to reclaim the solvent from the oil for reuse.

Bison Petroleum and Minerals Ltd., (9) a subsidiary of Canadian Javelin Ltd. of Montreal, has a solvent extraction process similar to that of Minerals Research Corp. Their extractor uses a moving screen to transport the tar sand under countercurrent solvent sprays and an infrared heat source. It is claimed that the heat from the propane or natural gas burners above the conveying screens softens the tar sand and improves the efficiency of solvent extraction. Bitumen recovery is more than ninety percent. The extracted sand is washed with fresh solvent and centrifuged to recover as much solvent as practical. Bison plans to build a two-ton per hour pilot plant in Canada in the near future. 
Stanford Research Institute (12) has one or more clients interested in and doing work on the solvent extraction of bitumen from tar sands. The detailed nature of this work is not known. However, both U.S. and Canadian tar sands are being studied.

Bingham Mechanical and Metal Products Corporation, (13) Idaho Falls, Idaho, has developed a cold solvent extraction process and has built and operated a 300 barrel per day pilot plant. In the conditioning step of their process, the oil is separated from the sand grains almost instantly. The water used in the process is recycled. They have been able to reduce the fines content of the bitumen to 0.1 percent. Bingham has a patent pending and is postponing further development work until it is issued. They estimate that they can build a 1,500 barrel per day plant for $\$ 1,500,000$.

LDK, Inc. (14), a salt lake City firm, has invented an anhydrous solvent extractor that dissolves the oil from the tar sand almost instantaneously. Solvent is recovered and recycled and little water is needed in their process. A portable 100 barrel per day unit has been built and is presently being tested. IDK believes that the poor econamics of small tar sand extraction. plants can be more than offset by portable equipment that can easily be moved to the richest deposit areas having a minimum of overburden to be removed.

\section{ENVIRONMENTAL ASPECTS}

The recovery of oil from Utah tar sands has many problems including economics, land ownership and use, water availability, remoteness of the deposits, land reclamation, urban development, and environmental pollution.

Present land ownership and use presents difficult problems which deter the recovery of oil from. the six main deposits. Much of the area of the deposits is on Federal land with a scattering of school sections (one square mile each) owned by the State. The Glen Canyon Recreational Area covers part of the Tar sand Triangle deposit and Canyonlands National Park is just east of it. Capital Reef National Monument covers much of the Circle Cliffs deposit and most of its remainder may soon become designated as primitive or wilderness area. Much of the Hill Creek deposit lies on the Uintah and Ouray Indian Reservation.

The water availability for the potential development of each tar sand deposit is critical. States in the Upper Colorado River Basin are allotted from between 5.8 and 7.5 miliion acre-feet of water per year. Current allocation estimates are about 5.8 
to 6.0 million acre-feet. Of this, Utah is allowed $23.0 \%$ or from 1.3 to 1.4 miliion acre-feet per year. In 1974 , depletions in the state were about 825,000 acre-feet leaving approximately 500,000 acre-feet of water unused by Utah. With the construction of authorized Bureau of Reclamation projects, Utah will have committed all but 107,000 acre-feet per annum and will have to select priorities carefully for the best use of its remaining entitlements.

Most large Utah deposits are within pumping distance of the Green River which carries over three million acre-feet per year at any point where diversion for tar sand development might be desirable. Only on the Circle cliffs deposit would pumping be from a river other than the Green (or Colorado) River as this deposit is bypassed by the Escalante River. To provide flow into the Green River water might be used from Flaming Gorge Reservoir which has approximately 500,000 acre-feet per year available for use. Also the proposed Tyzack Reservoir could make available 8,000 acre-feet per year into the Green River.

of the 500,000 acre-feet presently unused, unperfected claims exist for 13,056,000 acre-feet. In other words the available water is potentially all used twenty-six times over. Of course, many of these claims will never be granted and energy resource development is currently high on the list of priorities. The figures do not include depletions due to water rights under Winter's Doctrine (for Indian Reservations), development of Naval oil Shale by the Department of the Navy, Bureau of Land Management projects, water required by the Forest Service to maintain wildife and fisheries, and water possibly withheld by the wild and Scenic Rivers Act.

It is evident that some water is available and should not prevent tar sand oil development in Utah; however, negotiating the specifics of providing water to developers has historically taken time. As Governor Calvin I. Rampton(15) stated concerning water for development of oil shale, "I am sure we can provide them their allocation of water," but he said the procedural aspects of making water available would take most of a year, requiring legislative action.

Coal, oil shale, and tar sand energy developments will have to compete keenly with others to obtain rights to the water they need. Utah Power and Light Company (I6) has obtained water for new power plants in central and southern Utah by purchasing or leasing the water from the farmers. Utah Power and Iight Company has completed the first of six 430 megawatt coal-burning power plants to be in service by 1984. Four of these plants will be built in Utah. Each will require 7,000 acre feet of water per year if conventional water cooling towers are used. Utah Power 
ERRATA: Revision of Page 17

and Iight presently has the capacity to generate 1768 megawatts of electric power. They project a need to expand to 9500 megawatts by the year 2000. In 2000, a total of 140,000 acre feet of water per year will be required if conventional cooling towers are used. This water requirement might be reduced if the new wet-dry cooling towers are used. Wet-dry cooling towers use air for cooling in the winter and the conventional evaporative water cooling technique in the summer.

The remoteness of the deposits presents additional problems. Accessibility to several of the six deposits is difficult since only unimproved roads are presently available. Remoteness makes it difficult and costly to obtain supplies, equipment and spare parts and to market the products.

Reclamation of surface mined land may be required even though most of the large tar sand deposits are in areas where there is little vegetation or wildlife. The State of Utah is in the process of defining regulations. covering surface mining and reclamation requirements. Some states require top soil to be saved separately, the overburden replaced to the approximate contour of the premined area, the top soil replaced, and the area revegetated. In a semi-arid climate, it may be necessary to irrigate reclaimed areas for a year or more to re-establish vegetation. With water availability already critical, this presents a difficult problem.

Dr. Cyrus McKell(17), Professor of Range Science and Director of the Institute for Land Rehabilitation at Utah state University, believes that most of eastern Utah is too arid and water is too costly to establish new productive crops on reclaimed areas after surface mining. Instead, he is studying the re-establishment of vegetation native to the mined areas.

The Utah State Legislature and other Utah officials are planning carefully for energy resource development in Utah. A package of "Energy Bills" was passed during 1974 and 1975 and other bills are presently under consideration. Mining bills which were passed include SB256, SB257, SB260, SB290, SJR19, HB323, and HBI11. Energy research bill HB243 was passed. SB258 and $S B 259$ relate to the prepayment of taxes for funding roads and other needed facilities.

Public hearings are held as needed to inform the public of these new laws and their implementation. A public hearing was 
held on $22 \mathrm{July} 1975$ by the state Board of Oil, Gas and Mining, A Division of the State's Department of Natural Resources, on the proposed rules for the "Mined Iand Reclamation Act of 1975." Representative Genevieve Atwood(I8), chief sponsor of the Act, said that the law is general in its requirements although specific in intent so that the Oil, Gas and Mining Board has to formulate mined-land reclamation rules to carry out the intent. The rules require each mining company to state what they will do to reclaim the land and to post surety to guarantee it will be done. The oil, Gas and Mining Board decides whether the proposed reclamation is adequate and sees that it gets done.

Mr. Cleon Feight (18), Director of the Division of Oil, Gas and Mining, said that the Board had no intention of putting any company out of business. He said that in some cases the surety for reclamation required by the law could be a written, nonmonetary contract instead of surety bonds. The new law includes the requirement that reclaimed land be safe, and ecologically and hydrologically stable as judged by the Board.

Rapid urban development in the energy rich Uintah Basin is already a serious problem. Roosevelt and Duchesne have become boom towns because of the recent development of the AltamontBluebell oil field. Tar sand and oil shale developments would cause an additional rapid influx of workers and produce new boom towns wherever processing facilities are built. It is very difficult to supply adequate living accommodations, infrastructure, and community services for such rapidly growing areas in a short period of time. Localized population "growing pains" are another challenge which will accrue with tar sand oil recovery.

\section{ECONOMICS}

A comparison of tar sand oil recovery with conventional crude oil recovery may help to explain why companies have been reluctant to engage in tar sand oil recovery. The capital investment required before oil production begins is very large in the case of a tar sand oil facility. The average cost of drilling a 13,000 foot deep crude oil well in Utah is only $\$ 1,200,000$ and oil production begins immediately, unless the well is a "dry hole." The existence of an oil resource is certain in the case of a tar sand deposit, whereas crude oil development is problematical when drilling a conventional well. The extent of a tar sand deposit is usually defined by outcrops and by shallow core drilling. The extent of a crude oil field is unknown until many wells have been arilled. The economics of a tar sand oil production project are speculative. Unless 
the plant operates continuously near design capacity, losses will occur. Even with operations above design capacity only a modest profit can be expected since high expenses continue for the life of the plant. Once a good producing crude oil well is found, the probability is high that additional wells can be drilled nearby and high profits can be realized since both risk and expenses are low. Large companies have acquired leases and ownership of tar sand and oil shale lands, but are waiting until the relative economics of plant construction improve before going ahead on such projects. "The (oil) industry will have to turn to the Utah (tar) sands before long..." said an official of Tom Brown Drilling Company (19) of Midland, Texas.

The economics of oil recovery from the tar sands of Athabasca, Alberta, Canada will not be applicable to eastern Utah, but may give an indication of the order of magnitude of the various costs.

Great Canadian 0 il Sands Ltd. (20) produced 45,700 barrels of synthetic crude oil per calendar day during 1974 and sold it for $\$ 6.48$ per barrel. Total production costs and facilities were $\$ 5.76$ per barrel. The capital investment of the GCos plant in 1973 dollars was $\$ 5,270$ per barrel daily capacity. of this capital investment thirty-seven percent went for mining and extraction, thirty-one percent for bitumen upgrading to synthetic crydey and thirty-two percent for utilities. At the syncrude (ZI) project presently under construction, annual operating costs of $\$ 31,700,000$ on 50,000 barrels per day are expected to be distributed as follows: forty-one percent for mining, twenty-two percent for oil extraction, and thirty-seyen percent for oil upgrading to synthetic crude oil. Baillie(22) presents curves which show the effect of oil content and overburden ratio on relative operating costs. If the tar sands are exposed (no overburden) and the oil content is nine percent, operating costs are the same as with an overburden ratio of 0.4 and twelve percent oil content or with an overburden ratio of 1.0 and sixteen percent oil content. At a constant oil content of nine percent operating costs increase by fifty-five percent for a 0.5 overburden ratio and by 113 percent for a 1.0 overburden ratio compared to costs without overburden. Camp (6) says that the Athabasca tar sands have a maximum thickness of about 300 feet and an average thickness of about 150 feet. An overburden thickness of 120 feet is normally regarded as the practical limit for surface mining at Athabasca.

A number of small Utah companies believe that an oil from tar sands plant designed for low volume can operate profitably. Several such companies are Arizona Fuels, Fairbrijgy LDK, and Bingham Mechanical and Metal Products. D. Gill(23) says that 
Arizona Fuels and Fairbrim expect to spend $\$ 450,000$ to $\$ 700,000$ each for 5,000 barrel per day plants to produce oil at costs of $\$ 6$ to $\$ 8$ per barrel or from $\$ 90$ to $\$ 140$ per barrel daily capacity. These optimistic capital investments are far below the $\$ 5,270$ per barrel calendar day capacity for the GCOS plant at Athabasca, Alberta, Canada. D. Gill says, "At current prices, extracting crude from oil sands in Alberta and Utah looks on paper as though it ought to turn a profit." An earlier report says that Arizona Fuels expect their solvent and hot water process to be profitable at about $\$ 6$ per barrel, compared with $\$ 11$ or more per barrel estimates for oil from shale. Peters and Timmerhaus(25) indicate that doubling plant capacity of many industrial plants increases capital investment by a factor of 1.50 (two to the 0.6 power). In spite of this rule to build large plants, small plants may be economical if oil content is high and overburden thickness is low.

D. Van DeGraaf ${ }^{(26)}$ was not quite as optimistic as Arizona Fuels and Fairbrim. He said that depending on the degree of Federal financing the industry receives, tar sand oil will have to sell for $\$ 9$ to $\$ 12$ per barrel and oil shale oil for perhaps as much as $\$ 15$ per barrel to be economical. He said that early in 1975, crude oil in Utah sold for $\$ 6.28$ per barrel with 1974 sales totaling $\$ 237,000,000$. The average oil well costs $\$ 1,200,000$ to drill and is 13,000 feet deep.

John Oakason (27), Owner of Petroleum Investment and Research Corporation, is an energy resource wholesaler who bought and resold much of the Tar Sand Triangle tar sand deposit. He is of the opinion that tar sand oil recovery will be less costly than coal gasification or oil recovery from oil shale. He estimates that tar sand oil may cost $\$ 12$ per barrel.

H. C. Hottel and $J$. B. Howard (28) indicate that the need for technological sophistication in recovering oil from non-petroleum fossil deposits increases from tar sands to oil shale to coal. Also the atomic hydrogen to carbon ratio of 1.5 for tar sands and 1.6 for oil shale is more favorable than the 0.7 to 0.9 ratio range for coal.

\section{COMPARISON OF UTAH AND ATHABASCA TAR SAND DEPOSITS}

The largest tar sand deposit in the world is in the Athabasca area in Alberta, Canada. This deposit contains more than 700 billion barrels of oil; however, only about ten percent of this quantity is recoverable by surface mining methods. (6) By comparison, the tar sand deposits of Utah are much smaller at 28 billion barrels of oil, even though Utah has more than ninety percent of the tar sand reserves in the United States. An 
accurate determination of the percentage of Utah's tar sand oil that is recoverable by surface mining methods has not yet been made. Similar to Athabasca, this percentage for Utah is believed to be quite low. For example, it appears that only twelve percent of the Asphalt Ridge deposit can be economically surface mined.

That portion of the Athabasca tar sand deposit that can be surface mined economically, about ten percent, is relatively large, level, thick and continuous. These amenable characteristics led GCOS into using huge bucketwheel excavators and conveyor belts for mining the ore and draglines for moving the overburden. Syncrude plans to use the smaller conventional electric power shovel and truck method of mining.

Most of Utah's tar sand ore bodies are relatively small, thin and discontinuous and occur in beds with considerable dip. Overburden thickness is highly variable since the deposits are in mountainous terrain. The huge equipment used by GCOS could not be used at any of the Utah deposits because such equipment lacks maneuverability. It seems probable that drilling and blasting of both the overburden and the tar sand ore will be required at five of the six largest Utah deposits due to rock consolidation. Much of the Asphalt Ridge deposit seems to be soft enough to mine with rippers and elevated scrapers without drilling and shooting.

Great Canadian Oil Sands, Itd (GCOS, A Sun Oil Company subsidiary) has pioneered the production of synthetic crude oil from Athabasca tar sands using the K.A. Clark hot water extraction process. (6) GCOS has been in operation on a commercial basis since 1967, but 1974 was their first profitable year. Recent double-digit annual inflation rates have contributed strongly to the improved profitability of the GCos operation.

Proposed tar sand projects other than GCOS have encountered economic difficulties.(29) A team of companies under the name Syncrude Canada Ltd. planned a 125,000 barrel per day hot water extraction plant with coking and hydrotreating to upgrade the recovered bitumen. One member of the syncrude team, Atlantic Richfield Company, withdrew from the venture due to a four-fold inflationary increase in construction cost estimates since 1972. The remaining partners are Canada-Cities service Itd., Imperial Oil Ltd., and Gulf Oil Canada Itd.

A second project, a steam drive in situ process with thermal cracking and hydrotreating of the recovered bitumen, scheduled for completion in 1981 by Shell Canada Ltd. and partner Houston's Shell oil company has encountered similar inflation problems. An additional deterrent is the prospect of not being able to export the synthetic crude produced to refineries in the U.S. because Canada has decided to phase out such exports. 
A third 103,000 barrel per day plant proposal has been shelved by Home Oil Company for lack of partners in a consortium.

A fourth group of companies consisting of Petrofina Canada, Pacific Petroleum Company, Hudson Bay Oil and Gas Company, Murphy Oil Company, and CanDel oil Ltd. are re-examining their plans for a $122,500 \mathrm{~B} / \mathrm{D}$ extraction plant originally scheduled for completion in 1982 .

By comparison there are no existing commercial tar sand operations in Utah and only one company, Arizona Fuels Corporation, is actively engaged in building small process facilities. It is anticipated, however, that there will be increased interest in oil recovery from Utah tar sands in the near future as crude oil becomes more expensive because of the need to drill deeper wells and to depend upon secondary and tertiary oil recovery methods.

The sand grains of the Athabasca tar sands are typically encapsulated in a film of clay-laden water. The wet sand grains are then cemented together by the film of bitumen, the remaining voids being filled with water, air, and sometimes methane. $(6)$ The water and bitumen combined characteristically represent about seventeen percent by weight of the Athabasca tar sand. Of the eighty-three percent mineral matter in Athabasca tar sand, a substantial percentage of it is extremely small. Camp (6) defines these fines as clay (particles smaller than two microns) and silt (particles between two and forty-four microns). If the percentage of these fines is too high (above twelve percent) difficulties are encountered in the clark hot water process and an excessive amount of fines become suspended in the water from the extraction process and do not settle out at any appreciable rate. The result is that most of the used process water cannot be recycled and is ponded instead.

Utah tar sands do not have the characteristic Athabasca water envelope around the sand grains. In contrast, the water content of Utah tar sand is usualiy below one percent. Although the fines content of Utah tar sand is highly variable even within a particular deposit, it is significantly less than the fines content of Athabasca tar sand. Utah tar sands are probably less water-wet than Athabasca tar sand due to the absence of the water envelope; however, Shea and Higgins (30) indicate that the use of a wetting agent at $\mathrm{pH}$ of 8 to 8.5 will enhance the separation of the sand from the bitumen.

Camp ${ }^{(6)}$ indicates that bitumen from Athabasca contains from four to six percent by weight sulfur. Bitumen from the two southeastern Utah deposits, Tar Sand Triangle and Circle Cliffs, have sulfur contents of about 3.5 weight percent. Ritzma(1) 
points out that the four giant Uintah Basin deposits are low in sulfur content averaging 0.35 weight percent sulfur. High sulfur feed stocks are of less value to an oil refiner since they demand extra corrosion protection and pollution control measures.

The Athabasca tar sand operations have been plagued by extremely long cold winters and short wet summers. Water must be drained from the muskeg for a year or more before the overburden on top of the tar sand ore can be removed. Winter temperatures reach $-60^{\circ} \mathrm{F}$. Winter mining operations at GCOS are stopped when the temperature falls below $-30^{\circ} \mathrm{F}$ because the frozen tar sand, which resembles concrete, causes extremely excessive wear on the cutting feeth of the giant bucketwheel excavators used to mine it. (31) In Canada, water for the Clark hot water extraction process is abundant. Disposal of waste water containing suspended particles of silt and clay presents a major problem which has not yet been satisfactorily resolved. Waste water impoundment is being practiced and solar evaporation is minimal in the cold wet climate.

In Utah, the winters are not so long or cold and water in the forms of precipitation and flowing rivers is scarce instead of abundant. Most of the Utah tar sand deposits are located in areas that have less than fifteen inches of precipitation annually. Sufficient water exists in Utah rivers for tar sand water processing, but there are many energy resource developments and other water uses which are competing keenly for the limited water that is available. 


\section{ASPHALT RIDGE}

\section{Geology}

The Asphalt Ridge bituminous sandstone deposit is located a few miles west and south of the city of Vernal, Utah in Uintah County. Asphalt Ridge is a hogback or cuesta about fifteen miles long which cuts diagonally across Township 5 South, Range 21 East in a northwest to southeast direction. The north end of the deposit cuts across the southwest corner of T4S, R2IE and penetrates slightly into T4S, R20E. The south end of the deposit cuts the southwest corner of T5S, R22E and extends more than halfway across the northern portion of T6S, R22E.

Ritzma (1) tells us that tar sand deposits occur in the Duchesne River Formation of Eocene Age and the Rimrock Sandstone member of the Mesaverde Formation of Upper Cretaceous Age. The areal extent of the deposit is between 20 and 25 square miles. There are from two to five separate pay zones more than five feet thick. The total thickness of all pay zones varies from ten to 135 feet. The oil in place reserve totals 1,048,000,000 barrels. Of this, 435 million is measured, $438 \mathrm{million}$ is indicated, and 175 million is inferred.

Figure 4 is a geologic cross profile of the Asphalt Ridge deposit presented by Covington(32), which shows the locations of the five pay zones and the various geologic formations in the area. The viewer of this profile is looking to the southeast. The pay zones dip to the southwest at angles of from 8 to 30 degrees. These dip angles severely limit the percentage of oil in place that can be recovered by surface mining.

The oil content of Asphalt Ridge tar sand varies widely from very low percentages to as high as 15 weight percent oil. The oil content at the Uintah County asphalt pit is about 10 weight percent oil or 40 to 45 gallons of oil per cubic yard. Water content is low, about one weight percent. Shea and Higgins(33) say that the sand grains are "mainly clear quartz and dark-gray quartzite, with minor quantities of cream chert, rose quartz, amethyst, and chalcedony." Asphalt Ridge tar sand weathers to a gray color, but the freshly exposed material is black and often soft enough to be molded in the hand.

\section{Surface Mining}

Open pit mining of tar sand has been in progress at various 


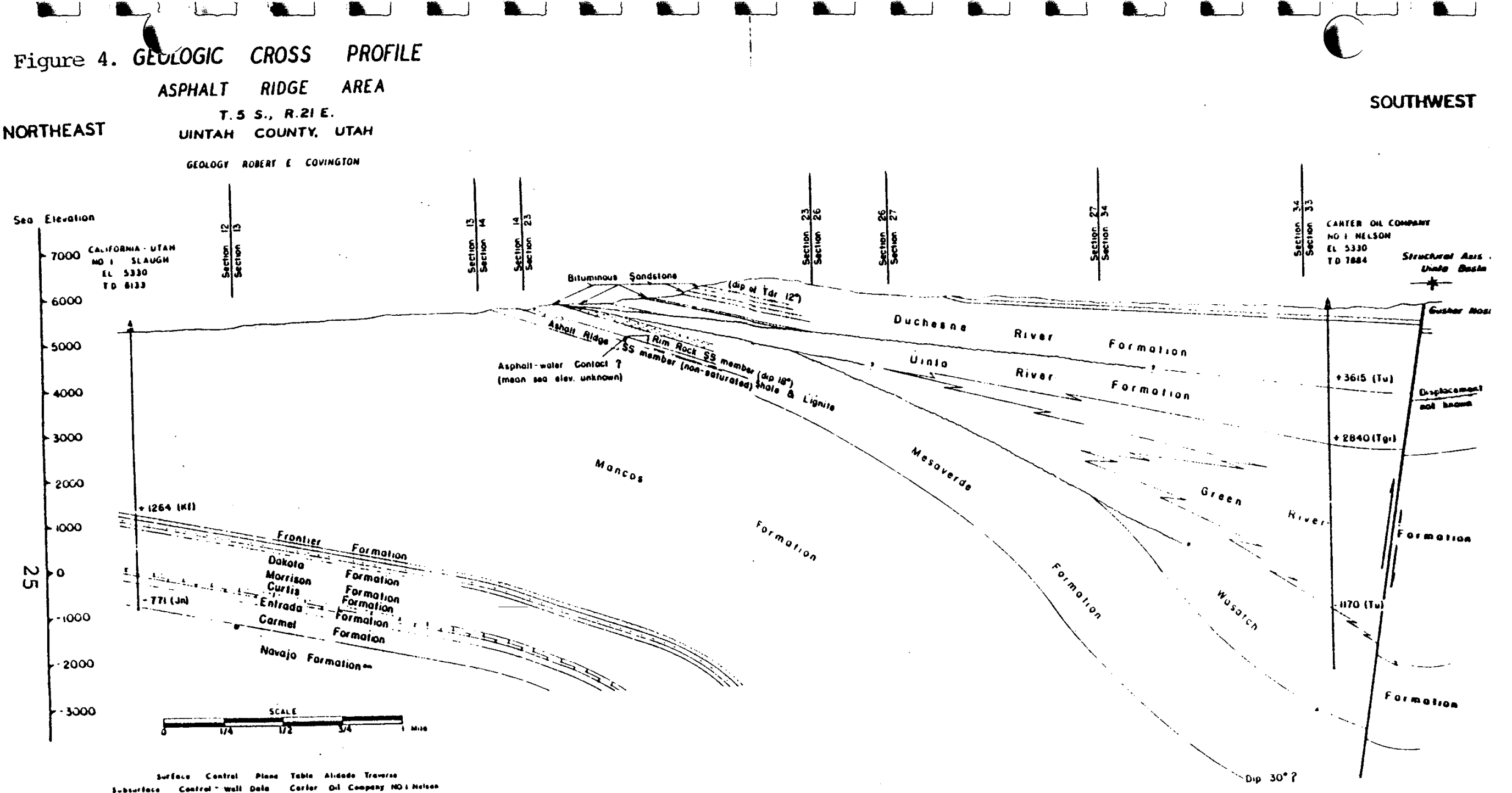

Figure 4. GEUĹOGIC CROSS PROFILE ASPHALT RIDGE AREA

UINTAH COUNTY. UTAH

gonear a covington

io lose

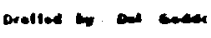

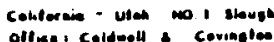


locations on Asphalt Ridge for at least 70 years as evidenced by several abandoned excavations. Tar sand has been mined for at least the last 35 years at the present Uintah County ten acre asphalt pit located about three miles west of Vernal's business district near the east boundary of Sections 30 and 31 , Township 4S, Range 21E. In $1974(34)$, a diesel-powered tractor equipped with "ripper" teeth was being used to loosen the rich asphaltlike ore. Up to 50 percent sand is mixed with the ore depending upon how rich it is in bitumen. The resulting mixture is loaded into dump trucks with a front-end loader. This mix is spread and rolled cold on 1100 miles of Uintah County roads and Vernal City streets as surface paving material. The economics of this operation were not studied since the ore tonnage mined each year is relatively small. An asphalt pit operator said that 25,000 cubic yards of tar sand was sold in 1974 for $\$ 3.50$ per cubic yard. The 1975 price has increased to $\$ 5.00$ per cubic yard.

The tar sand at the Uintah County asphalt pit is so weakly consolidated that it appears that the cohesive properties of the bitumen hold the sand grains in the matrix. Because of this weak consolidation, the tar sand can be mined with a ripper and a front-end loader. Drilling and blasting are not necessary.

On July 1, 1974, Sohio Petroleum Company, a subsidiary of Standard Oil Company (Ohio), applied to the Division of Oil, Gas, and Mining Conservation, Department of Natural Resources, State of Utah, to permit them to mine tar sands at Asphalt Ridge. The application requests permission to "commence mining operations for the removal and processing of the commercially mineable deposits of bituminous sands"(35) on 180 acres of Township 5s, Range 2lE, Section 36 owned by the State and Township 5S, Range $22 \mathrm{E}$, Section 31, fee lands owned by Sohio Petroleum Company. Sohio has water rights to five cubic feet per second of water from the Green River for the purpose of mining and processing tar sand. $(36)$

A public hearing was held at the Uintah county Building in Vernal, Utah on August 28, 1974 regarding Sohio Petroleum Company's application to open-pit mine tar sands seven miles south of Vernal on the Asphalt Ridge deposit. Mr. Robert M. Lowe, Tar Sands Project Manager for Sohio, read into the record a Sohio report entitled, "Proposed Plan for Mining and Processing Operations, Bituminous Sands Deposits, Asphalt Ridge Area, Uintah County, Utah with Particular Reference to the Environmental Effects of the Operations." In the following(36) Figure 5 , taken from the above report, is a contour map of Asphalt Ridge and vicinity. The area to be mined is cross-hatched and labeled "Area of Interest." Figure 6, taken from this same report, is a contour map which shows the area to be mined in greater detail. Table III, entitled Sohio Corehole Analyses, taken from the september, 1974 issue of "Synthetic Fuels" 

作

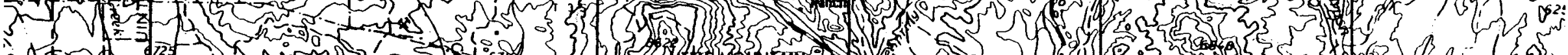

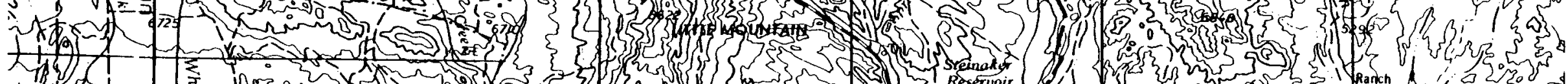

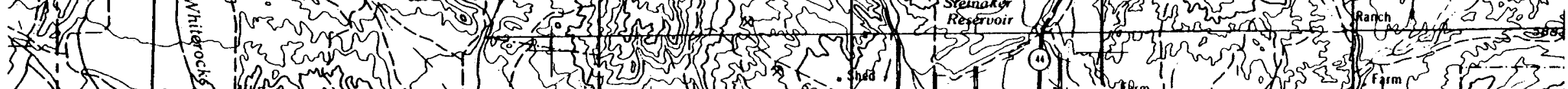
3) 4 . 200 年

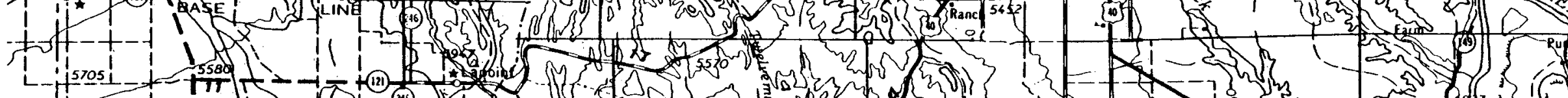
(1)

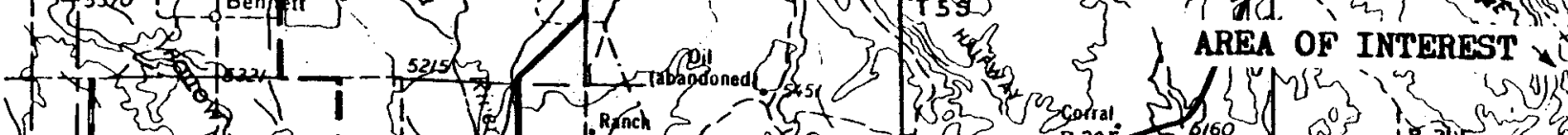

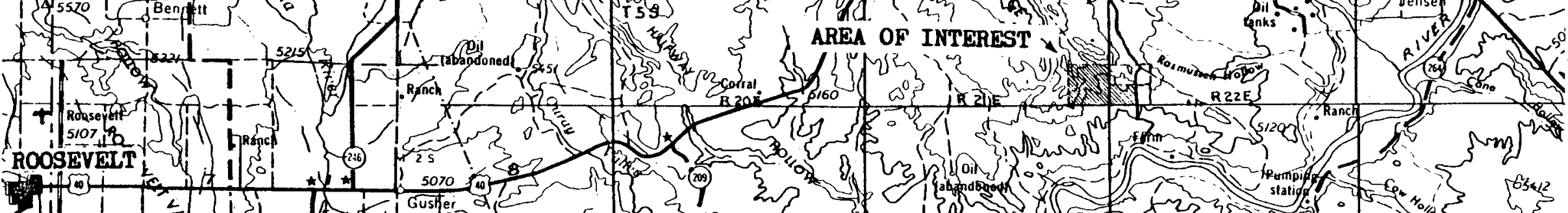
T1

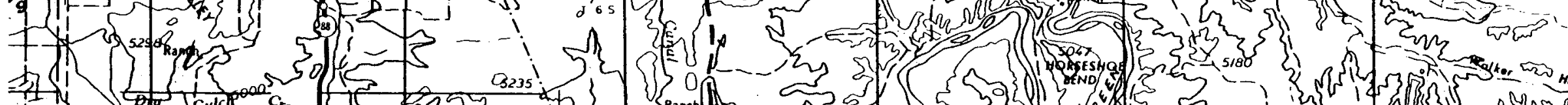
74)

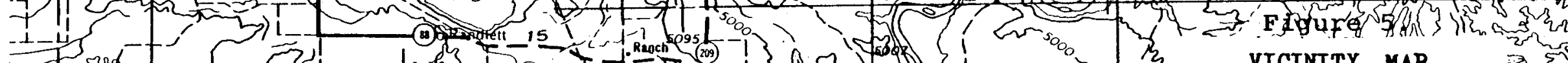

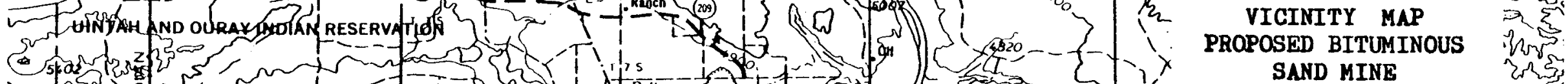

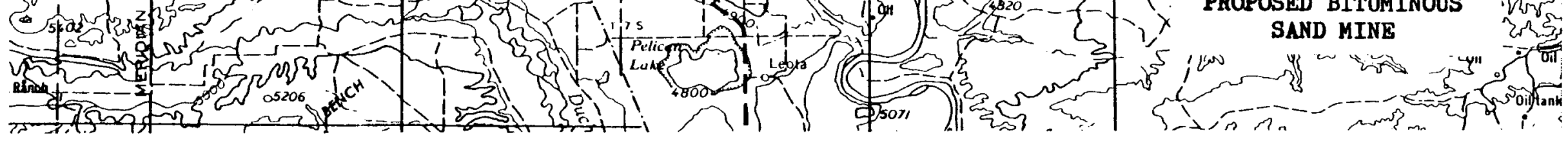



3) -

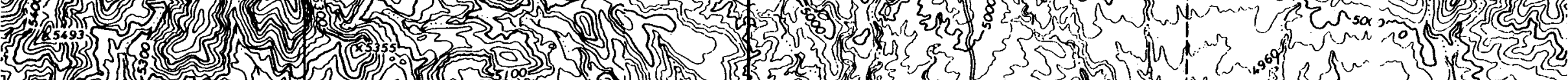
7 ) 38 (n)

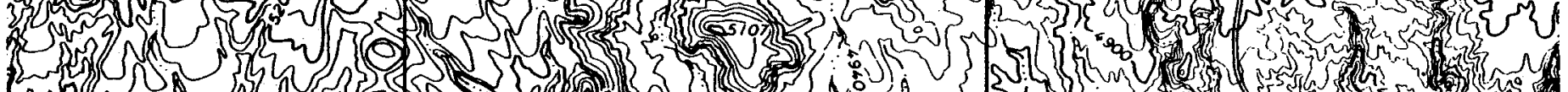
ons.

PROPOSED BITUMIHOUS 
Table III

SOHIO COREHOLE ANALYSES

Core CE-3

Ground Elevation $=5294 \mathrm{Ft}$.

\begin{tabular}{|c|c|c|c|c|c|c|c|}
\hline DEPTH & $\mathrm{Gal} . / \mathrm{Yd}^{3}$ & DEPTH & Gal. $/ Y d^{3}$ & DEPTH & $\mathrm{Gal} . / \mathrm{Yd}^{3}$ & DEPTH & Gal $/ / Y_{d}{ }^{3}$ \\
\hline $\begin{array}{l}67.5 \\
69.5 \\
71.5 \\
75.0 \\
79.0 \\
81.0 \\
83.0 \\
85.0 \\
86.0 \\
88.5 \\
91.0 \\
93.2 \\
95.0 \\
97.0\end{array}$ & $\begin{array}{l}23.0 \\
10.8 \\
36.8 \\
20.8 \\
27.1 \\
32.6 \\
27.1 \\
34.2 \\
32.2 \\
12.4 \\
45.9 \\
42.3 \\
49.5 \\
26.6\end{array}$ & $\begin{array}{r}99.4 \\
103.2 \\
106.0 \\
107.5 \\
113.5 \\
116.5 \\
117.7 \\
119.5 \\
120.8 \\
122.4 \\
123.8 \\
128.1 \\
129.7 \\
131.6\end{array}$ & $\begin{array}{r}23.9 \\
35.0 \\
36.8 \\
38.9 \\
43.7 \\
0.5 \\
46.4 \\
37.6 \\
44.8 \\
42.6 \\
24.2 \\
44.2 \\
43.7 \\
13.6\end{array}$ & $\begin{array}{l}134.0 \\
138.2 \\
140.0 \\
141.6 \\
144.4 \\
146.0 \\
148.2 \\
149.5 \\
152.0 \\
154.2 \\
156.0 \\
158.0 \\
160.0 \\
162.3\end{array}$ & $\begin{array}{r}9.2 \\
14.7 \\
37.2 \\
27.0 \\
15.9 \\
32.8 \\
39.0 \\
48.0 \\
40.7 \\
48.7 \\
45.5 \\
39.7 \\
46.1 \\
36.3\end{array}$ & $\begin{array}{l}163.8 \\
166.0 \\
168.0 \\
172.3 \\
173.8 \\
176.0 \\
178.0 \\
180.0 \\
183.8 \\
186.0 \\
187.5 \\
190.0 \\
192.0 \\
203.0\end{array}$ & $\begin{array}{r}41.7 \\
35.0 \\
43.9 \\
24.5 \\
25.3 \\
18.3 \\
27.6 \\
0.7 \\
9.7 \\
35.7 \\
43.9 \\
6.0 \\
13.3 \\
15.6\end{array}$ \\
\hline
\end{tabular}

Core CE- 2

Ground Elevation $=5200 \mathrm{Ft}$.

\begin{tabular}{|c|c|c|}
\hline DEPTH & $\mathrm{Gal} \cdot / Y d^{3}$ & DEPTH \\
\hline $\begin{array}{r}8.5 \\
11.0 \\
12.5 \\
14.5 \\
16.5 \\
18.0 \\
30.0 \\
32.0 \\
34.0 \\
36.0 \\
38.0 \\
40.0 \\
42.0\end{array}$ & $\begin{array}{l}46.4 \\
27.5 \\
48.9 \\
23.4 \\
25.8 \\
10.3 \\
25.1 \\
36.5 \\
36.8 \\
32.5 \\
36.7 \\
15.1 \\
42.4\end{array}$ & $\begin{array}{l}44.0 \\
46.0 \\
47.0 \\
50.0 \\
51.5 \\
54.3 \\
56.0 \\
61.0 \\
63.0 \\
65.0 \\
67.0 \\
69.0 \\
74.0\end{array}$ \\
\hline
\end{tabular}

\begin{tabular}{|c|c|c|c|c|}
\hline Gal. $/ Y d^{3}$ & DEPTH & Gal. $/ Y^{3}{ }^{3}$ & DEPTH & Gal. $/ Y_{d}^{3}$ \\
\hline $\begin{array}{r}33.2 \\
31.6 \\
50.6 \\
14.6 \\
37.6 \\
20.9 \\
8.8 \\
20.3 \\
18.9 \\
30.5 \\
23.6 \\
18.5 \\
6.4\end{array}$ & $\begin{array}{r}78.0 \\
80.0 \\
82.0 \\
84.0 \\
86.5 \\
88.0 \\
105.0 \\
106.5 \\
108.0 \\
111.0 \\
115.0 \\
119.0\end{array}$ & $\begin{array}{r}54.3 \\
16.5 \\
46.2 \\
40.2 \\
31.3 \\
21.7 \\
12.6 \\
7.8 \\
20.2 \\
3.5 \\
30.6 \\
46.2\end{array}$ & $\begin{array}{l}121.0 \\
124.7 \\
127.7 \\
129.0 \\
130.5 \\
134.7 \\
136.0 \\
140.7 \\
142.5 \\
143.5 \\
145.5 \\
151.5\end{array}$ & $\begin{array}{r}13.4 \\
4.0 \\
14.0 \\
14.9 \\
4.9 \\
31.6 \\
4.6 \\
7.7 \\
23.7 \\
43.2 \\
5.2 \\
2.8\end{array}$ \\
\hline
\end{tabular}

Core F-1

Ground Elevation $=5073 \mathrm{Ft}$.

\begin{tabular}{|c|c|c|}
\hline DEPTH & $\left.G_{a}\right] \cdot / Y_{d}^{3}$ & DEPTH \\
\hline $\begin{array}{l}32.0 \\
34.0 \\
36.0 \\
42.0 \\
46.0 \\
50.0 \\
52.0 \\
54.0 \\
60.0 \\
62.0 \\
64.0 \\
78.0 \\
80.0\end{array}$ & $\begin{array}{l}25.8 \\
22.9 \\
19.0 \\
25.0 \\
16.2 \\
29.8 \\
40.0 \\
46.3 \\
27.4 \\
48.3 \\
44.4 \\
31.5 \\
33.7\end{array}$ & $\begin{array}{r}82.0 \\
84.0 \\
88.0 \\
90.0 \\
94.0 \\
96.0 \\
98.0 \\
100.0 \\
102.0 \\
103.5 \\
106.0 \\
108.0 \\
110.0\end{array}$ \\
\hline
\end{tabular}

\begin{tabular}{rrr} 
Ga1. $/ Y^{3}$ & & DEPTH \\
\hline 29.5 & & 112.0 \\
23.6 & 120.0 \\
37.1 & 126.0 \\
42.6 & 128.0 \\
19.3 & 130.0 \\
6.3 & 132.0 \\
18.9 & 134.0 \\
26.4 & 136.0 \\
13.6 & 138.0 \\
36.9 & 142.0 \\
4.0 & 144.0 \\
26.0 & 146.0 \\
26.2 & 150.0
\end{tabular}

\begin{tabular}{ccc} 
Ga1. $/ Y_{d}^{3}$ & & DEPTH \\
\cline { 1 - 1 } 19.6 & & 152.0 \\
5.6 & & 156.0 \\
1.8 & 158.0 \\
15.7 & 160.0 \\
12.3 & 162.0 \\
13.4 & 164.0 \\
22.4 & 166.0 \\
15.8 & 168.0 \\
12.7 & 170.0 \\
28.6 & 172.0 \\
30.6 & \\
25.2 & \\
7.1 &
\end{tabular}

\begin{tabular}{c}
$G a 1 . / Y d^{3}$ \\
\hline 4.8 \\
14.9 \\
20.1 \\
34.5 \\
28.7 \\
15.8 \\
10.0 \\
17.4 \\
2.2 \\
0.7
\end{tabular}


published quarterly by Cameron Engineers, Denver, Colorado, presents the depth in feet and the oil content of the tar sand core samples in gallons of oil per cubic yard of ore. According to Synthetic Fuels, September, 1974, 25 gallons of oil per cubic yard of tar sand corresponds to six weight percent oil. Mr. Lowe testified that the tar sand pay thickness in the area to be mined ranges up to 175 feet and averages about 65 feet. A portion of attachment number one to Sohio's mining application is presented as Figure 7. This topographic map shows the location of the three core holes and the initial mining areas. The dark areas are tar sand outcrops.

The hearing and question period afterward was very favorable for approval of Sohio's application. The only significant objection raised during the question period was some concern regarding the future maintenance required on the county road which would be used by the oil trucks to transport bitumen from the mine area.

The actual open-pit mining and chemical processing to separate the oil from the tar sand was to be done by two firms, Arizona Fuels Corporation and Fairbrim Company. The clean sand will be returned to the mined out area and the land reclaimed in a terrace plan submitted in the application. Information regarding the processing methods to be used by Arizona Fuels and Fairbrim to separate the oil from the tar sand may be found under Chemical Processing (in the following section).

The Sohio Petroleum application to mine tar sand was approved. Fairbrim Company changed their plans and moved their extraction equipment to a tar sand deposit in Kentucky near Mammoth Cave. In July, 1975, it was reported on the KSL-TV News that Fairbrim was producing 10 barrels per hour of bitumen with their extractor in Kentucky. Arizona Fuels began mining operations on forty acres of Sohio fee land during the summer of 1975. Approximately 150,000 cubic yards of overburden has been removed and about 4,000 cubic yards of tar sand has been stockpiled during 1975 . Eleven core holes with a total footage of 1714 feet were drilled to more accurately define the resource at the mine site. The mining operation has utilized one ripper tractor and two seven cubic yard front-end loaders.

Chemical Processing

Table IV presents analyses of Asphalt Ridge tar sand and oil reported in the literature. 

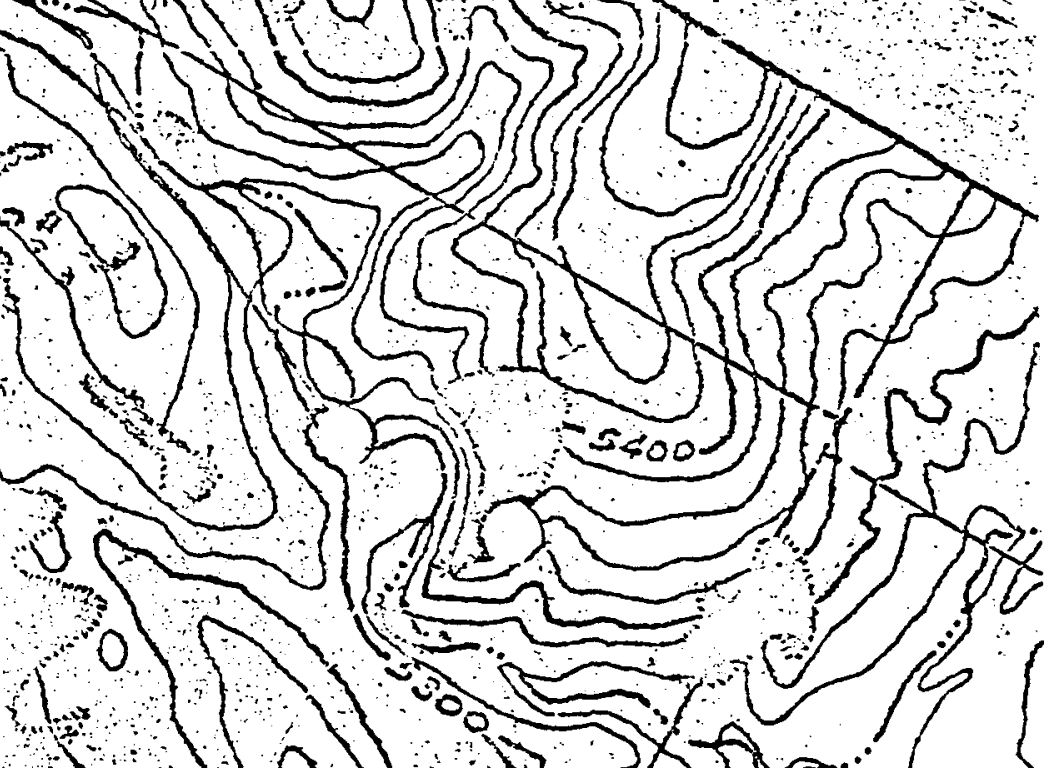

is $25 \mathrm{~s}$

on 25012

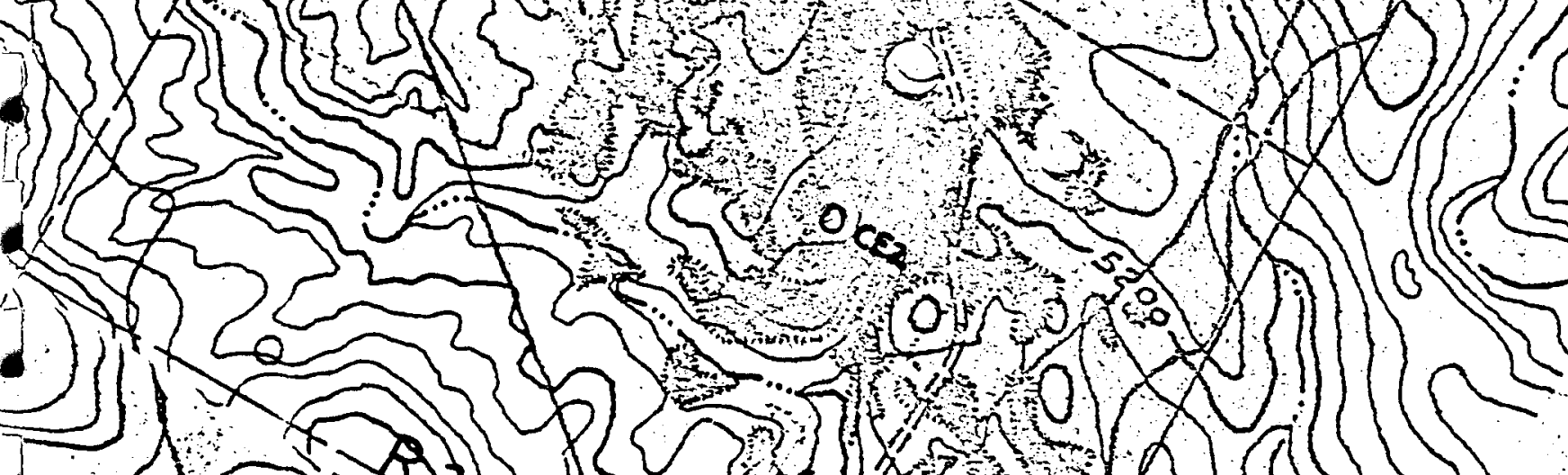

4525

(2) 1 (

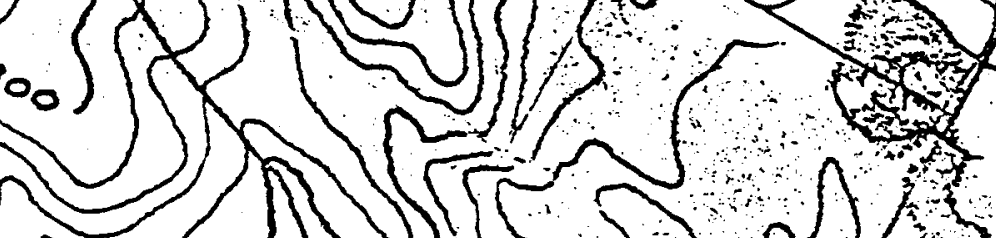

S

2 
Table IV

ASPHALT RIDGE TAR SAND AND OIL ANALYSES

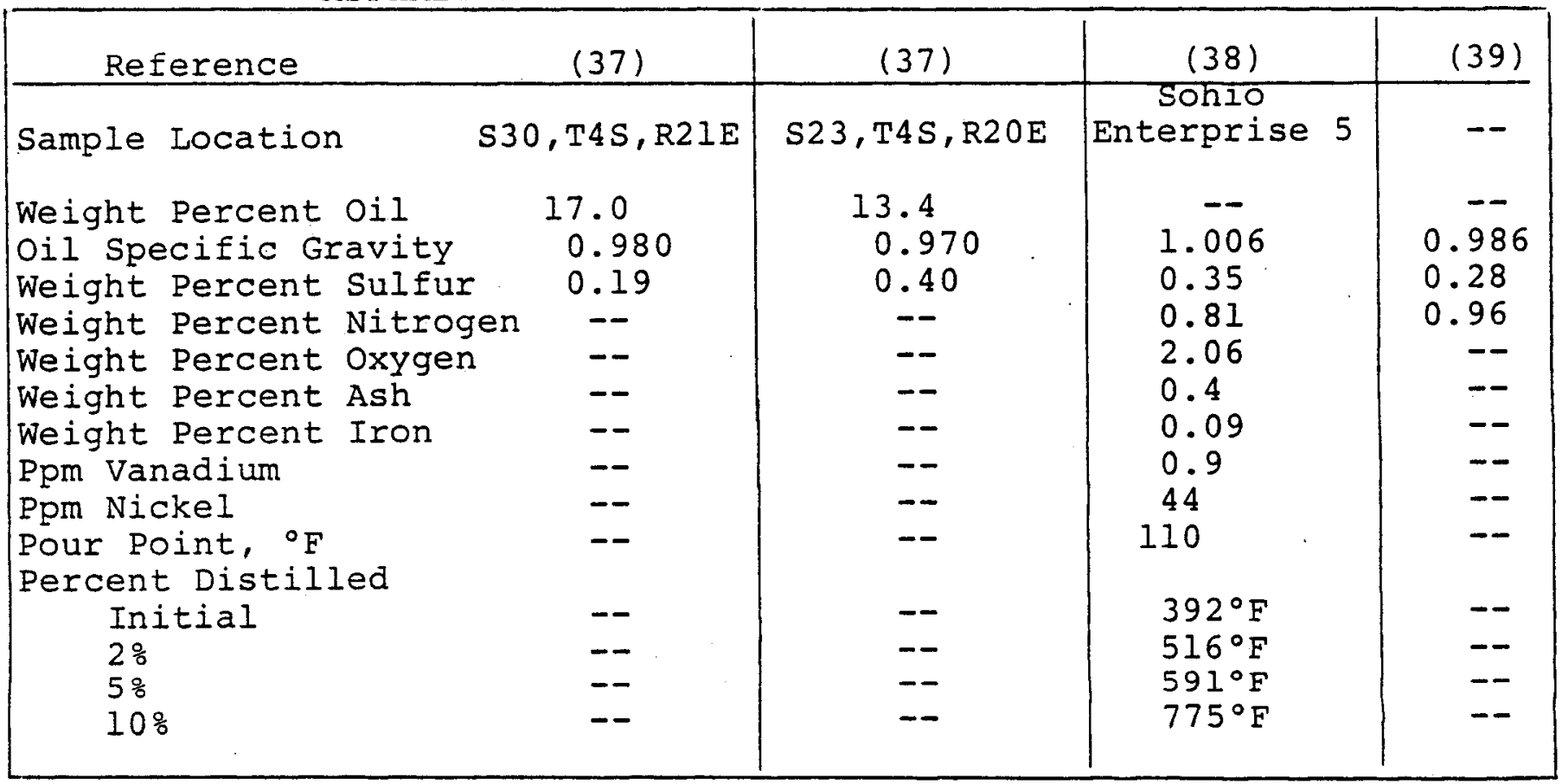

Table IV indicates that the specific gravity of extracted tar and oil from Asphalt Ridge is slightly less than that of water. The sulfur content of the oil is consistently below 0.5 weight percent. This is an important property of the oil since high sulfur oil causes corrosion and air pollution problems during refining. Kayser(39) found that the portion of his bitumen sample boiling below $572^{\circ} \mathrm{F}$ was free of wax as indicated by a cloud point below $5^{\circ} \mathrm{F}$.

Spieker(40) reports that an Asphalt Ridge bitumen sample contained 3.6 percent asphaltous anhydrides, 19.0 percent asphaltenes, 45.8 percent resins, and 31.6 percent oils. Kayser (39) comments that this high resin content accounts for the high adhering and ductile properties of Asphalt Ridge bitumen.

Covington(41) tells an interesting story related to the ductile properties of Asphalt Ridge tar sand. Years ago (about 1960), a load of Asphalt Ridge tar sand was taken to Denver to patch some roads. A few years later, the patches had become bumps in the road. The road surfacing material around the patches had worn down much more rapidly than the patches. Covington describes Asphalt Ridge tar sand as being extremely tenaceous and very resistant to wear as a road paving material.

On July 16, 1975 on KSI-TV news, Mr. Lynn Packer described the maintenance problems with Utah's asphalt or black top paved roads. He and Mr. Blaine Kay, Director of the Utah Department 
of Transportation, explained that the asphalt produced at the Salt Lake Area refineries lacks ductility because of the nature of the crude oil available to the refineries. The paving material cracks easily because the hydrocarbons in it are too brittle and do not stretch sufficiently during cold winter days. High paraffin content of the asphalt increases brittleness. Repeated freezing and thawing causes these cracks to form chuckholes and other failures of the paving material. Other factors contributing to high maintenance problems on Utah roads include the presence of excessive fines in the aggregate and the use of hard asphalt.

Possibly, the quality of asphalt produced by refineries in the Salt Lake Area could be improved if Asphalt Ridge bitumen were included in their crude $\mathrm{mix}$. This bitumen has been found to be free of wax. (39) The presence of mineral matter and metals should be studied as possible disadvantages of direct processing. Nickel and vanadium are known to be fluid catalytic cracking catalyst poisons. Vacuum distillation of the bitumen should remove these catalyst poisons from the distilled oil fractions, however.

Even if Asphalt Ridge or other bitumen is found to be useful in the production of road asphalts, this market is quite limited. It was learned from $M r$. C.V. Anderson, Chief Engineer of the Utah State Department of Transportation, that Utah's projected needs for asphalt paving material in 1975 total 106,000 tons of asphalt. A tar sand extraction plant having a capacity of only 2000 barrels per day could supply this total requirement.

At the request of $\mathrm{Mr}$. Harvey Alford of Sohio Petroleum's Cleveland, Ohio research laboratories, several oil companies in the Salt Lake City area were contacted to determine whether or not they are interested in the future processing of tar sand oil from Asphalt Ridge near Vernal, Utah. Mr. L.H. Butterworth, Manager of Amoco's North Salt Lake Refinery, expressed an interest in tar sand oil as a possible asphalt flux. Presently, Amoco is purchasing flux oil from Tenneco who has oil wells near Escalante, Utah. Mr. Butterworth indicated that Amoco would probably not be interested in tar sand oil to replace crude oil unless it were coked and hydrogen treated to produce synthetic crude oil.

Mr. D.L. Blanke of Amoco's Crude Oil Purchasing Department in Chicago, was quite interested in Utah tar sand oil as a future source of crude oil. He would like to receive physical property data on tar sand oil so that his people can make a preliminary evaluation of it.

In July, $1975 \mathrm{Mr}$. R.M. Lowe, Sohio's Tar Sand Project Manager, sent physical property data on Asphalt Ridge bitumen, vacuum distillate, and coker distillate obtained by vacuum distilling 
the bitumen and coking the bottoms to $\mathrm{Mr}$. Blanke. These data are proprietary.

The crude purchasing people of Phillips Petroleum Corporation and Chevron oil Company have also been contacted to determine the prospective market for tar sand oil from Asphalt Ridge near Vernal, Utah.

Mr. Robert J. Alfrey, Vice President in Chevron's Denver office, said that Chevron is not interested at this time in processing tar sand oil at their North Salt Lake refinery since they do not make asphalt. Another problem arises in the transportation of tar sand oil as it is not compatible with the waxy Altamont crude which they move over their heated pipeline from the Uinta Basin to North Salt Lake, and Chevron cannot unload crude oil trucks at the Salt Lake Refinery. Before any interest could be developed in synthetic crude oil formed by coking and hydrogen treating tar sand oil, samples would have to be analyzed for determining the suitability as a refinery feedstock.

Mr. W.L. Young of Phillips Petroleum's crude evaluation section at Bartlesville, Oklahoma, seemed interested in future availability of tar sand oil for processing at Phillips' Woods Cross refinery. He indicated that the local (Salt Lake area) market for asphalt and heavy fuel oil limits the crude running rate at the woods Cross refinery. Lighter products can be shipped by pipeline to the northwest. He estimated that tar sand oil may be worth about two dollars per barrel less than the crude produced by coking and hydrogenating it. The hydrogenated oil should have a value close to new domestic crude prices. He suggested that coke might be marketed in the Chicago area since coke is presently being shipped to Chicago from Bakersfield, California. He indicated that Phillips might be interested in receiving a two-barrel sample of tar sand oil when it becomes available so they can make evaluation tests on it.

\section{Environmental Aspects}

Surface mining operations on the Asphalt Ridge deposit should not be significantly disturbing to the environment. As has been mentioned earlier, only a strip of land about one-fourth mile wide and about 12 miles long is mineable. This type of mining could be classified as contour mining. Reasonable reclamation practice should improve the land since there is little vegetation or wildife at the present time.

The Asphalt Ridge deposit has the advantage of being near the agricultural community of Vernal. Numerous canals and a reservoir feed the area's farms. Ashley Creek, just north of Vernal, and its tributaries are the chief contributors to the water supply and after all depletions, Ashley Creek still has an annual 
flow of 44,000 acre-feet into the Green River. Part of this water might be made available to an Asphalt Ridge extraction plant via an agricultural canal.

Sohio Petroleum(10) has water rights to five cubic feet of water per second or 3600 acre-feet of water from the Green River. This volume of water should be adequate for an extraction plant associated with the surface mining of the Asphalt Ridge deposit.

The Asphalt Ridge area is hilly and already severely eroded. Vegetation is sparse because the area receives only an average of eight inches precipitation per year and most of this comes during the spring months. The scanty vegetation consists of sparse grasses, short sagebrush and an occasional juniper.

Mined land should be reclaimed by level terracing and the replanting of more useful vegetation. Surface material should be segregated and spread over spent extraction sands to promote revegetation. The Utah State Forest Service has suggested (35) the replanting of Russian wild rye, crested wheat grass, yellow sweet clover, gray rabbit brush, black sage, and four-winged salt brush. The water requirements for replanting vegetation may be a problem.

The most common forms of wildlife in the area are lizards and morning doves. There are also a few mice, gophers, squirrels, chipmunks, rabbits, chukars, and desert birds. Surface mining is expected to cause wildlife in the mined areas to move to other nearby areas and not to be significantly destructive.

Surface mining operations can be expected to create some noise and dust. These should not be a problem except to the mine operators since Asphalt Ridge is three miles from the city of Vernal at its nearest point.

Dust problems can be minimized by paving existing dirt roads and mine traffic areas with lean tar sand. It is anticipated that little water will be available for the purpose of combating dust unless dust becomes a problem to residents near the mine site. Air pollutants other than dust are not expected to be a problem. Emissions from diesel-powered equipment will be insignificant. Hot or cold water tar sand processing equipment should not cause significant air pollution even if bitumen is used as fuel since Asphalt Ridge bitumen has a low sulfur content. If solvent processes are used, solvent losses to the air must be minimized for economy reasons as well as for air pollution reasons.

The socio-economic impact of surface tar sand mining and processing at Asphalt Ridge should not be severe. The average annual growth rate of Vernal during the years 1970 to 1973 has 
been 7.4 percent. The 1973 population of Vernal was 4924 . Sohio Petroleum estimates that two mining and extraction plants having capacities of 3500 barrels per day each will employ a total of 60 men. This many new jobs may cause a population increase of nearly 500 people or a population growth of about ten percent when the impact on local services and facilities is considered. Such growth due to tar sand resource development is not expected to occur in a single year, however. The socio-economic impact of in situ mining can be expected to be much greater than that of surface mining.

\section{Conclusions}

The Asphalt Ridge tar sand deposit is only large enough to support one surface mining processing plant having a maximum capacity of 17,000 barrels of bitumen per calendar day. This maximum capacity is based on a process plant life of 20 years and the assumption that only twelve percent of the $1,048,000,000$ barrel oil reserve(1) is recoverable by surface mining methods. Even if it were economical to remove up to 150 feet of overburden, a strip of land only one-fourth mile wide would be surface mined since the ore body dips southwestward at an average angle of apout ten degrees. Of the 20 to 25 square mile areal extent (1), only about three square miles can be surface mined. The Asphalt Ridge deposit is the most suitable of the six deposits studied as a testing ground for pilot plants and small demonstration units. It has (1) good oil saturation, (2) good pay thickness, (3) excellent water availability, (4) low sulfur content, (5) minimal land ownership problems, and (6) good access to facilities and product market. 


\section{CIRCLE CLIFFS}

One of the two giant Utah tar sand deposits in central southeast Utah is known as the "Circle Cliffs" deposit. The areal extent of this deposit is about 28 square miles in Garfield county. The Circle cliffs deposit is divided into two major deposits which have been named the West Flank and the East Flank. The West Flank lies within Townships 34 and 35 South, Ranges 6,7 , and 8 East. The East Flank lies in Townships $33,34,35$ and 36 South, Ranges 7, 8, and 9 East. The Escalante River is about six miles southwest of the West Flank. The East Flank deposit is almost entirely within the Capitol Reef National Park.

\section{Geology}

Ritzma (42) describes the tar sand oil of the Circle cliffs deposit as being "trapped in the unnamed middle sandstone member of the Triassic Moenkopi Formation in a sequence of fine-grained clayey, micaceous sandstones interspersed with occasional pods of porous and permeable beach and off-shore bar-type sandstones." Ritzma (43) presented a diagrammatic geological cross section of the Circle Cliffs Uplift (see Figure 8) and a map of the Circle cliffs outcrops (see Figure 9).

\section{Surface Mining}

The Utah Geological and Mineral Survey(I) states that the tar sand oil reserve at the Circle Cliffs is as follows. The East Flank contains 420,000,000 measured barrels, plus 340,000,000 indicated barrels, and 100,000,000 conjectured barrels for a reserve of $860,000,000$ barrels. The West Flank contains $287,000,000$ measured barrels, 90,000,000 indicated barrels, and $70,000,000$ conjectured barrels for a reserve of $447,000,000$ barrels. The total reserve for both flanks is 1,307,000,000 barrels of oil in place.

It is possible to surface mine more than 30 percent of the deposit area; however, overburden thickness varies from zero to more than 500 feet. There are from one to three pay zones which vary in thickness from minimal to about 300 feet.

A number of factors discourage surface mining of the circle Cliffs deposit. By and large, the deposit is very lean although in some areas saturated tar sand may be found. These rich areas 


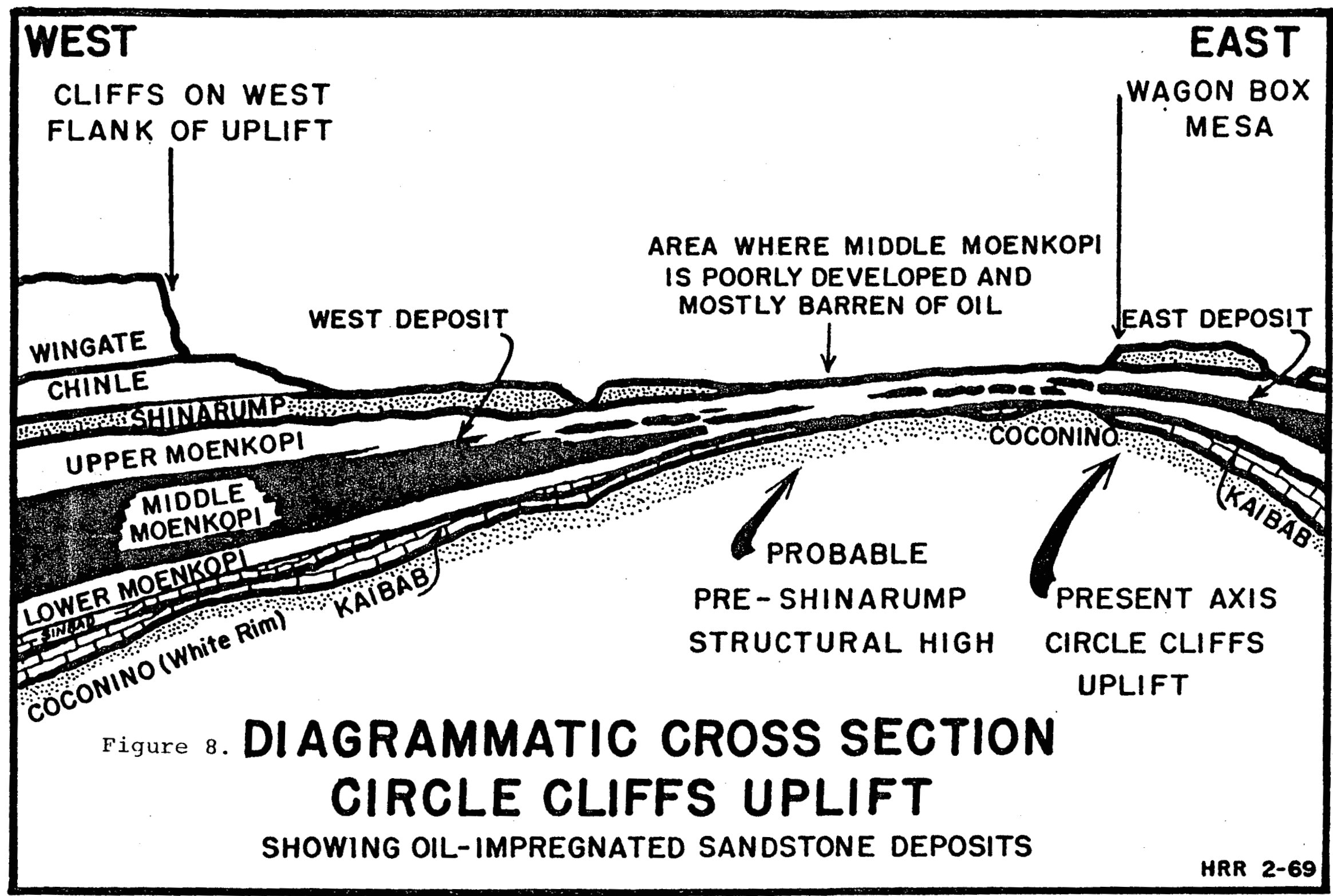

n 


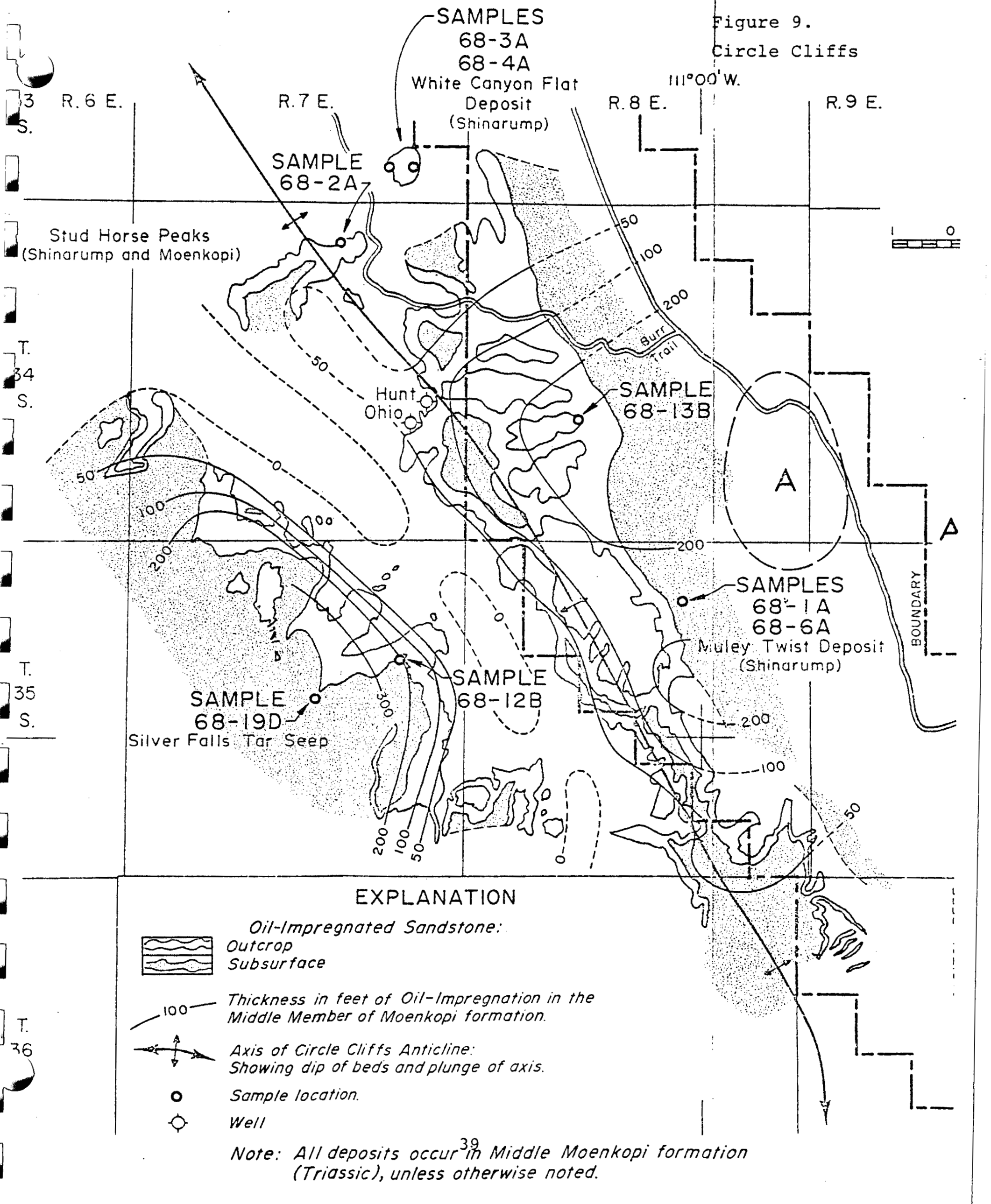


are widely scattered. The terrain is rugged and not well suited for the largest mining equipment. Drilling and blasting will be required to surface mine this deposit. The deposit is very remote from population centers and presently quite inaccessible.

Austral oil Company drilled two exploratory core holes near the west edge of the Circle Cliffs West Flank deposit. One core hole was drilled to 860 feet in Section 7 of T35S, R6E about two miles from the outcrop. Core samples at that location were still saturated with oil but the pay thickness was only one-half of the thickness at the outcrop and the tar sand was compacted. The second core hole was drilled to 989 feet about one mile further south in Section 18 of T35S, R6E. No tar sand deposition was found in this second core.

\section{Chemical Processing}

Surface mining methods may be used to recover bitumen from the Circle Cliffs since much of the deposit area is near the surface. In areas where overburden thickness is prohibitive, it may not be feasible to recover the bitumen by in situ methods due to tar sand compaction, low porosity, and low bitumen content. The presence of considerable siltstone may interfere both with in situ recovery and bitumen-sand separation of surface-mined material.

As in the case of the Tar Sand Triangle bitumen, the circle Cliffs bitumen has a relatively high sulfur content. This relatively high sulfur content is a significant deterrent to marketing the bitumen as a feedstock to refineries. High sulfur stocks are corrosive and require special processing and air pollution abatement equipment.

Wood and Ritzma (37) report analyses of twelve samples taken from the Circle cliffs tar sand deposit. The average oil content of eleven of these samples (a seep was omitted) was only 4.6 weight percent. Oil extracted from these twelve samples had an average specific gravity of 1.103 and an average sulfur content of 3.60 weight percent. Atmospheric and vacuum distillation data are also presented by these authors. These data indicate that the circle cliffs deposit is undesirable in at least three respects when compared with the Uinta Basin deposits. The tar sand is poorly saturated with oil, the oil is unusually heavy, and the oil contains a high percentage of sulfur.

Arjay oil Company(44) arilled four cores at Circle cliffs and found an oil content of 7.5 weight percent in one selected 80 foot string of core. 


\section{Environmental Aspects}

The arid climate in the Circle Cliffs area is a major problem. The area receives less than ten inches of precipitation annually and most of this is winter snowfall and spring rains. There is little vegetation or animal life in the area. Sprinkling or irrigation will be required to re-establish vegetation in reclaimed areas. The nearest source of water is from the 50,000 acre-feet annual flow in the Escalante River about six miles southwest of the deposit. Obtaining water rights from the Escalante for tar sand chemical processing and land reclamation will probably be difficult since the Escalante is being reviewed for consideration under the Wild and Scenic Rivers Act.

Land ownership and use are serious problems deterring tar sand development at Circle Cliffs. The East Flank deposit lies almost entirely within Capitol Reef National Park which is under the jurisdiction of the National Park Service. The West Flank is principally on Federal land controlled by the Bureau of Land Management. As is the case with much of the Federal land in Utah, the State owns several school sections in many of the townships. Environmental groups are attempting to have the West Flank area designated as a wilderness or primitive area. Such designation will probably severely restrict the availability of the deposit to surface mining.

The remoteness of the Circle Cliffs area from possible bitumen markets is another disadvantage.

\section{Conclusions}

Of the six largest tar sand deposits in the Intermountain West that are possible candidates for a large surface mining operation, the Circle cliffs deposit ranks next to the lowest. The principal reason for this low ranking is the low oil content of the tar sand. Other factors which discourage the exploitation of the Circle cliffs tar sand deposit are as follows: (1) high clay and silt content of the ore, (2) high sulfur content of the oil, (3) rugged terrain, (4) remoteness and inaccessibility, (5) lack of water for processing and land reclamation, and (6) the present use of the area as a national park and possible designation as a wilderness area.

Circle Cliffs will probably maintain its low ranking unless core drillings can identify a large portion of the Circle cliffs deposit with ten percent or more of oil saturation. 


\section{HILL CREEK}

Geology

The giant Hill Creek tar sand deposit lies just west of the P.R. Spring deposit on the east side of the Green River. It is located in Townships 13, 14, and 15 South, Ranges 18, 19, 20, and 21 East in Uintah County. Figure 10 is an overlay of the location of the deposits as indicated by UGMS Map $33^{(1)}$ and a portion of a Utah State Department of Highways map which shows the boundaries of the Hill Creek Extension of the Uintah and ouray Indian Reservation. The two roughly rectangular areas indicate that more than one half of the deposit lies on the Indian reservation. Other smaller tar sand deposits which lie on the Uintah and Ouray Indian Reservation are as follows: Littlewater Hills (10 to 12 million barrels), Lake Fork ( 6.5 to 10 million barrels), and Spring Branch ( 1.5 to 2 million barrels).

The Hill Creek tar sand is found in the Douglas Creek Member of the Green River Formation (Eocene Age). The dominant lithology of the Douglas Creek Member is sandstone and siltstone.

Surface Mining

The Utah Geological and Mineral Survey(1) states that the tar sand oil reserve at Hill Creek is as follows: 350 million measured barrels, plus 480 million indicated barrels, and 330 million inferred or conjectured barrels for a total reserve of 1,160 million barrels of oil in place. The deposit covers an area of from 115 to 125 square miles. There are from one to three pay zones that vary from five to thirty-five feet in thickness. Overburden thickness varies from none at all at the outcrops on the sides of the canyons and washes to more than 500 feet.

Surface mining of the Hill creek deposit would consist principally of contour mining. This is true since in many areas the deposit outcrops on canyon walls and is quickly covered by excessive overburden as the ore body is followed perpendicular to the canyon. Drilling and blasting will be required since both the overburden and pay zones are well consolidated.

The Indians (45) on the Uintah and Ouray Indian Reservation would like to more accurately determine the extent of the mineral resources on their tribal lands; however, they are presently not able to finance the extensive core drilling and geological work needed to do this. 


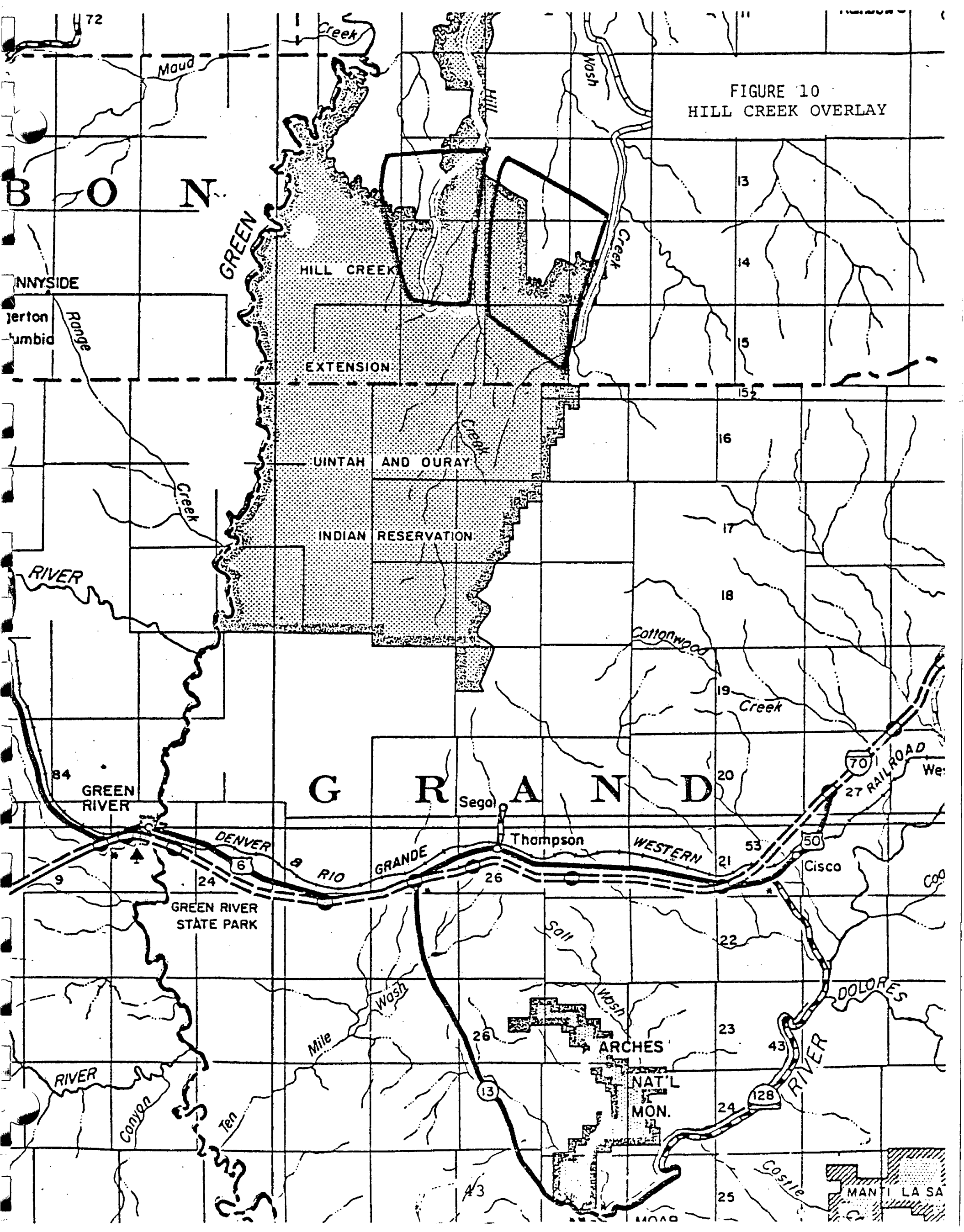


Wood and Ritzma(37) report an oil content of 11.2 percent on a sample of tar sand taken from the Hill Creek deposit at Tl4S, R2OE, Section 30 beside the Oil sand Canyon road. Oil extracted from this sample had a specific gravity of 1.017 and a sulfur content of 0.40 weight percent. Atmospheric and vacuum distillation data are also presented by these authors.

\section{Environmental Aspects}

Water for the large scale chemical processing and mined land reclamation in the Hill creek tar sand deposit must come from the Green River. The Green flows about six miles west of the deposit at its nearest point.

The Indians (46) on the Uintah and Ouray Indian Reservation are concerned about the role they will play during the development of the energy resources found on the reservation. Socio-economic and multi-cultural development can progress more smoothly if energy development on the reservation involves the Indians as much as possible. This can be accomplished, in part, by locating production facilities on the reservation near the ore bodies instead of exporting the resources for processing beyond the reservation.

\section{Conclusions}

Data on the tar sand resource at Hill Creek are extremely limited. However, it is recommended that resource evaluation efforts be concentrated on other more promising deposits. The writers rank the Hill Creek deposit lowest of the six deposits studied, as far as large-scale surface mining is concerned. The principal reasons for this low ranking are that the three pay zones are thin and widely scattered. When the oil reserve of 1,160 million barrels is divided by the 125 square mile area of the deposit, a quotient of only 9 million barrels of oil per square mile is obtained. This is the lowest quotient for any of the six deposits studied. The quotients for the other deposits vary from 17 to 70 million barrels per square mile. Although the percentage of the oil reserve that is surface mineable was not evaluated, it is obvious that the deposit cannot support an extraction plant requiring a one biliion barrel surface mineable reserve. Other disadvantages of the deposit are as follows: (1) the mountainous terrain, (2) the dry climate, (3) poor accessibility, and (4) the remoteness of the deposit from product markets. The deposit has the advantage of containing low sulfur oil. Land ownership by the Indians may be an advantage over federal or multiple private ownership. 
It is recommended that a preliminary overburden thickness study be made to determine the percentage of the deposit area that can be surface mined. 


\section{P.R. SPRING}

Utah's second largest tar sand deposit in oil reserves and the largest in areal extent has been named "P.R. Spring" after a spring lorated near the east boundary of the deposit. P.R. Spring may be an abbreviation for peor Spring which has been said to mean "bad water". The writers could find nothing wrong with the water nor with the mule deer who shared it with them.

P.R. Spring covers from 240 to 270 square miles in eastern Utah in the southeast portion of the Uinta Basin. It lies within Townships 12 through 17 South, Ranges 21 through 25 East in Uintah and Grand Counties and extends eastward to the Colorado state line.

\section{Geology}

Marchant, et al (47) describe the P.R. Spring area as follows: "Surface elevations in the P.R. Spring deposit area decrease northward from over $8,000 \mathrm{ft}$. at the Roan Cliffs, at the southern extremity, to about $6,000 \mathrm{ft}$. near Threemile canyon. The topography is characterized by steep-walled canyons divided by flat ridges. Surface water is limited to a few small spring-fed perennial streams in the major canyons. Access to the area from the north is via graded dirt roads from Bonanza and Ouray. Unimproved trails descend from the Roan Cliffs to connect with Interstate Highway 70 to the south."

"Geologically, the P.R. Spring deposit is in the southeast portion of the Uinta Basin. Most of the surface is composed of one of the members of the Eocene-Green River Formation (Table V). The floors of several deeper canyons are on the wasatch Formation and the Uinta Formation outcrops on a small portion of the north end of the deposit."

"The oil-saturated beds of the upper Douglas Creek and lower Parachute Creek Members of the Green River Formation outcrop near the top of the Roan Cliffs and dip north-northwest at about $2^{\circ}$. At the poorly defined north end of the deposit the tar sands are below several hundred feet of overburden. The tar sands also outcrop along the walls of the deeper canyons and several oil and water seeps are found in these outcrops." 
Table V

TERTIARY FORMATIONS OF THE

SOUTHEASTERN UINTA BASIN

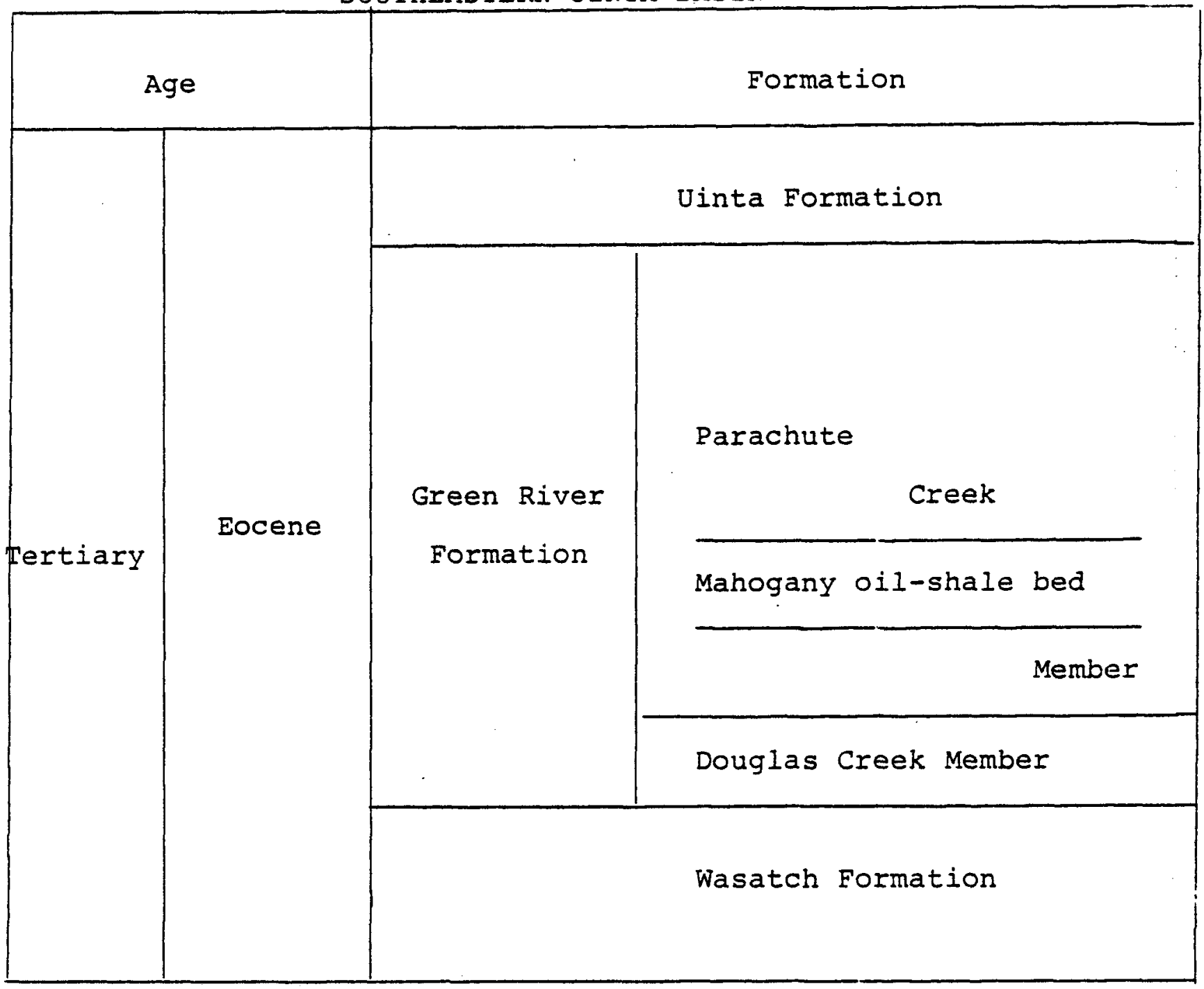


Surface Mining

Some areas of the P.R. Spring tar sand deposit can be surface mined in addition to contour mining of the outcrops along the canyon wails. Overburden thickness varies from none at all to more than 500 feet, however. Ritzma(1) tells us that there are from two to six separate pay zones that vary in thickness from zero to 80 feet. The total oil reserve is from 4.0 to 4.5 billion barrels of oil in place consisting of 2.5 billion barrels measured, 1.2 billion indicated, and 0.3 to 0.8 billion inferred or conjectured.

Tar sand outcrops sampled by the writers were well consolidated indicating that drilling and blasting will be required to surface mine the P.R. Spring deposit.

Chemical Processing

Wood and Ritzma(37) report analyses on three samples taken from the P.R. Spring tar sand deposit. Table VI presents these data.

Table VI

P.R. SPRING TAR SAND AND OII ANALYSES

\begin{tabular}{|l|c|c|c|}
\hline Reference & $(37)$ & (37) & (37) \\
\hline Sample No. & $69-13 E$ & $69-14 \mathrm{E}$ & $67-1 \mathrm{~A}$ \\
Weight Percent Oil & 12.4 & 14.8 & 97.6 \\
Dil Specific Gravity & 1.012 & 1.031 & 0.969 \\
Weight Percent Sulfur & 0.45 & 0.35 & 0.36 \\
\hline
\end{tabular}

Sample 69-13E was taken in the Dragon-Asphalt Wash area (SW NE 8, T12S, R25E) from the uppermost Douglas Creek Member of the Green River Formation (Eocene Age). The second sample (69-14E) was taken in the Dragon-Asphalt Wash area (NW NW 4, T12S, R25E) from the Parachute Creek Member of the Green River Formation oolite in contact with the Black Dragon gilsonite vein. The third sample (67-1A) was taken from an oil seep in Main Canyon (Center NE5, T16S, R24E) in the Douglas Creek Member of the Green River Formation. The sulfur content of these samples is low as with other Uinta Basin tar sand oil samples.

J.W. Bunger (48) has made a comparison of the properties of oil extracted from P.R. Spring tar sand and typical Athabasca tar sand. This comparison is presented in the following table. 
Table VII

COMPARISON OF P.R. SPRING AND ATHABASCA TAR SANDS

\begin{tabular}{|c|c|c|}
\hline Property & P.R. Spring & Athabasca* \\
\hline $\begin{array}{l}\text { API Gravity } \\
\text { Specific Gravity } \\
\text { Heating Value, Btu/1b } \\
\text { C/H, Atomic Ratio } \\
\text { Elemental Analyses }\end{array}$ & $\begin{array}{c}10.3 \\
0.998 \\
1,800 \\
0.637\end{array}$ & $\begin{array}{r}7.6 \\
1.018 \\
17,800 \\
0.669\end{array}$ \\
\hline $\begin{array}{l}\text { Carbon, wt. } \frac{8}{8} \\
\text { Hydrogen, Wt. } 8 \\
\text { Sulfur, Wt. } \frac{o}{8} \\
\text { Nitrogen, Wt. } \frac{}{8}\end{array}$ & $\begin{array}{r}84.44 \\
11.05 \\
0.75 \\
1.00\end{array}$ & $\begin{array}{c}83.28 \\
10.40 \\
2 \text { to } 6 \\
0.35 \text { to } 0.65\end{array}$ \\
\hline
\end{tabular}

*Average for Athabasca (Ref. 6, Camp, 1974, p.23)

The carbon-hydrogen ratio of 0.637 is average for Utah tar sand oil. The higher API gravity, higher hydrogen content, and lower sulfur content of P.R. Spring tar sand oils tend to make them more valuable than Athabasca oils as an energy resource.

Recent unpublished work by Bunger(11) confirms these earlier observations and extends the comparison to Asphalt Ridge and Tar Sand Triangle samples. The Asphalt Ridge sample paraliels the P.R. Spring while the Tar sand Triangle sample, which is much higher in sulfur and lower in hydrogen, parallels the Athabasca sample. However, the Uinta Basin samples are of a higher average molecular weight and viscosity and of a lower volatility which tends to offset the aforementioned advantages over the Tar Sand Triangle and Athabasca samples. The most significant compositional difference between the Uinta Basin oils on the one hand and the Tar Sand Triangle and Athabasca oils on the other, and which explains the property trends, is the higher concentration of saturated hydrocarbons in the Uinta Basin samples.

J.W. Bunger (48) compares simulated distillation results on a P.R. Spring tar sand oil sample, A, using gas-liquid chromatography with conventional distillations of other P.R. Spring samples by J.W. Gwynn $(49) \mathrm{B}, \mathrm{C}$, and $D$ and by Wood and Ritzma (37) $E$ and $F$ in Table VIII. Bunger suggests that the large volume of low boiling fractions in samples $E$ and $F$ may be due to thermal cracking of the original tar sand oil during distillation.

Bunger's 1974 paper also presents information about the major compound types in a P.R. Spring tar sand oil and shows that 
Table VIII

DISTILLATION DATA FOR P.R. SPRING BITUMENS (48)

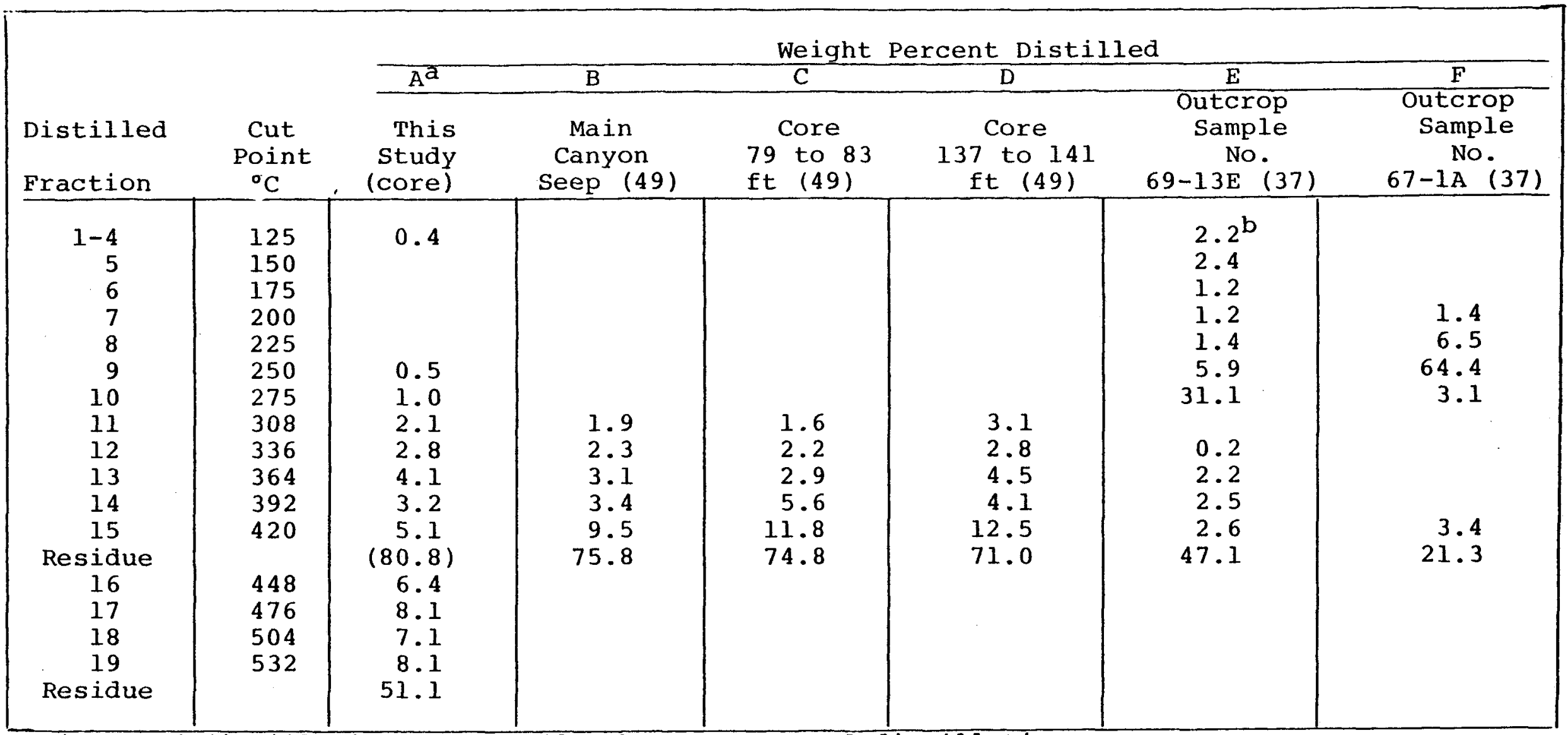

asimulated distillation data. All others are actual distillation.

bThe total value of 2.2 was found in fraction 4.

( ) Numbers in parentheses refer to references cited. 
it differed significantly from high-boiling petroleum residues. These differences were most notable in the higher percentage of bitumen which contained heteroatoms as well as the greater tendency for heteroatoms to be concentrated as a function of decreasing volatility. Because the absolute concentration of heteroatoms was not significantly different from a comparable high nitrogen Wilmington, California residue, these results were attributed to a higher average molecular weight for the P.R. Spring residue of comparable initial boiling point.

\section{Environmental Aspects}

As is the case with the other tar sand deposits studied, the climate is arid and little water is available within the vicinity of the deposit. The drainages of Willow Creek (50) and Upper Willow Creek contribute respectively 17,500 and 13,000 acrefeet annually to the Upper Colorado River Basin system. However, 11,500 acre-feet of this is used for cropland and wet land depletion, leaving 19,000 acre-feet flowing into the Green River each year. This volume of water is not adequate for a sizeable tar sand industry. Water for a large mining and processing facility would have to be taken from the Green River which is at least 20 miles west of the deposit.

P.R. Spring has more vegetation than Asphalt Ridge, Circle Cliffs, or Tar Sand Triangle. Reclamation of surface-mined land may be more difficult than at Sunnyside but less difficult than at other deposits. The annual precipitation is about 15 inches. The most prominent plant in the area is sagebrush. The abundance of browse, the rolling hills of the plateau, and steep canyons have contributed to the production of an ideal mule deer hunting area.

Conclusions

The writers rank the P.R. Spring tar sand deposit the fourth most promising candidate for a large scale surface-mining operation. Although the deposit contains from 4.0 to 4.5 billion barrels of oil in place, the tar sand ore is widely scattered over a 270 square mile area. When the oil reserve of 4.5 billion barrels is divided by this 270 square mile area, a quotient of only 17 million barrels of oil per square mile is obtained. This quotient is the second lowest of the six deposits studied. Other factors which contribute to the low ranking of the P.R. Spring deposit are as follows: (1) heavy overburden coverage except near the south end of the deposit, (2) wide separation of the two to six pay zones by barren material, (3) remoteness and inaccessibility, (4) lack of water for processing and land reclamation, and (5) predominant land ownership by the Federal 
government. The deposit is very remote from population centers, good roads, a railroad, electric power, and oil markets. Consideration could be given to the installation of a products pipeline or gravity-conveying system southward down the Book Cliffs to the Denver and Rio Grande Western Railroad and Interstate Highway 70 which pass through the towns of Thompson and cisco.

Much of the P.R. Spring deposit may be found to be satisfactory for in situ oil recovery. 
SUNNYSIDE

\section{Geology}

The Sunnyside tar sand deposit is located in Carbon county, Utah in Townships 12, 13 and 14 South, Ranges 13,14 and 15 East. The deposit outcrops for nine miles along the southwest side and near the top of the Book Cliffs. At its closest point, the deposit is four miles northeast of the coal mining town of Sunnyside, which is a terminal point of the Denver and Rio Grande Western Railroad. The deposit can be reached by driving about three miles up whitmore Canyon and then about five miles via an unimproved road up water Canyon.

Most of the oil saturation occurs in the upper third of the 3700 foot thick Wasatch Formation of Lower Eocene Age. Some saturation occurs in the lower overlying beds of the Green River Formation of Middle Eocene Age. Holmes, et al (5I) indicated that the pay zones are from 10 to 350 feet thick within a 1000 foot interval between the elevations of 9000 and 10,000 feet. The outcropping beds dip gently northeastward into the Uinta Basin at angles from 3 to 10 degrees. Outcrops can be found in the canyons of Dry Creek and Range Creek on the dip slope northeast of the crest of the Book Cliffs.

Ritzma(1) says that there are from three to twelve pay zones that vary in thickness up to 550 feet.

The areal extent of the deposit is between 35 and 90 square miles and the quantity of oil in place is estimated to be between 3.5 and 4.0 billion barrels. Ritzma(I) says that this oil reserve is the sum of 1.25 billion barrels measured, 1.75 billion barrels indicated, and 0.5 to 1.0 billion barrels inferred. This oil reserve places the sunnyside tar sand deposit third in size in Utah. Only the Tar Sand Triangle and P.R. Spring deposits are known to be larger.

Surface Mining

On October 17, 1974, J.M. Glassett accompanied three other men interested in tar sand deposits to Sunnyside, Utah. These men were Howard R. Ritzma, Assistant Director of the Utah Geological and Mineral Survey, Jock Campbell, Geologist for UGMS, and Dr. Alex G. Oblad, Dean of the College of Mines and Mineral Industries at the university of Utah. This group traveled 
southward to Price, Utah and then eastward about 30 miles to Sunnyside in a four-wheel drive vehicle. From the city of Sunnyside, they traveled northward up Whitmore canyon about three miles and then turned northeast into water Canyon. Figure 11 is a map of the area north of Sunnyside taken from a report by C.N. Holmes (51) and B.M. Page entitled "Geology of the Bituminous Sandstone Deposits Near Sunnyside, Carbon County, Utah." A one square mile area surrounding a rock asphalt or tar sand quarry was carefully mapped by these men in 1945 and is included in this report as Figure 12 .

Figure 12 shows that the tar sand deposit exposure is extensive, extending from the 9100 foot to the 10,000 foot elevation. The asphalt quarry is at about the 9,200 foot elevation. Open pit mining at one quarry began in 1892, to obtain paving material for the streets of Salt Lake City. A second quarry was opened in 1915. To 1945, about 330,000 tons of tar sand had been mined from this second quarry site and used directly to pave highways and airport landing strips. Drilling and blasting was required during these mining operations since the sunnyside tar sand is quite well consolidated.

Early in the history of the quarry, an aerial tramway was built to transport the tar sand down water Canyon about four miles to the base of the Roan Cliffs. The tar sand was then transferred to trucks, hauled to a crushing plant at sunnyside, and then transferred to railroad cars for delivery to the point of use. The tramway has apparently not been used for about 30 years, but is quite picturesque. The wooden tram towers are still there and the rusty buckets are still hanging on the cable. Howard Ritzma told us that the tramway was steep enough for the buckets to move down the canyon by gravity. Many of the workmen rode in the buckets on their return trip up the canyon to get to work.

In 1949, Utah Oil Refining Company $2 \pm$ North Salt Lake began to produce road asphalt with their propane deasphalting unit and several years later, Phillips Petroleum Corporation at woodscross also began asphalt production by vacuum distillation. These asphalt producers may have caused the demise of the sunnyside "rock asphalt" mining operation. These refiners began producing asphalt because the demand for black fuel oil decreased significantly after World War II ended.

On May 20, 1965, a hearing was held and Shell Oil Company was granted permission by Utah's Oil, Gas, and Mining Conservation Commission to drill five wells on one-acre spacing in section 3 , Tl4S, Rl4E in Carbon County. The application states that the Sunnyside Experimental Project involved the injection of steam to see if bitumen could be produced from the injection well or from adjacent wells. A maximum drilling depth of 1500 feet was specified. The results of this project were not found during this study. 


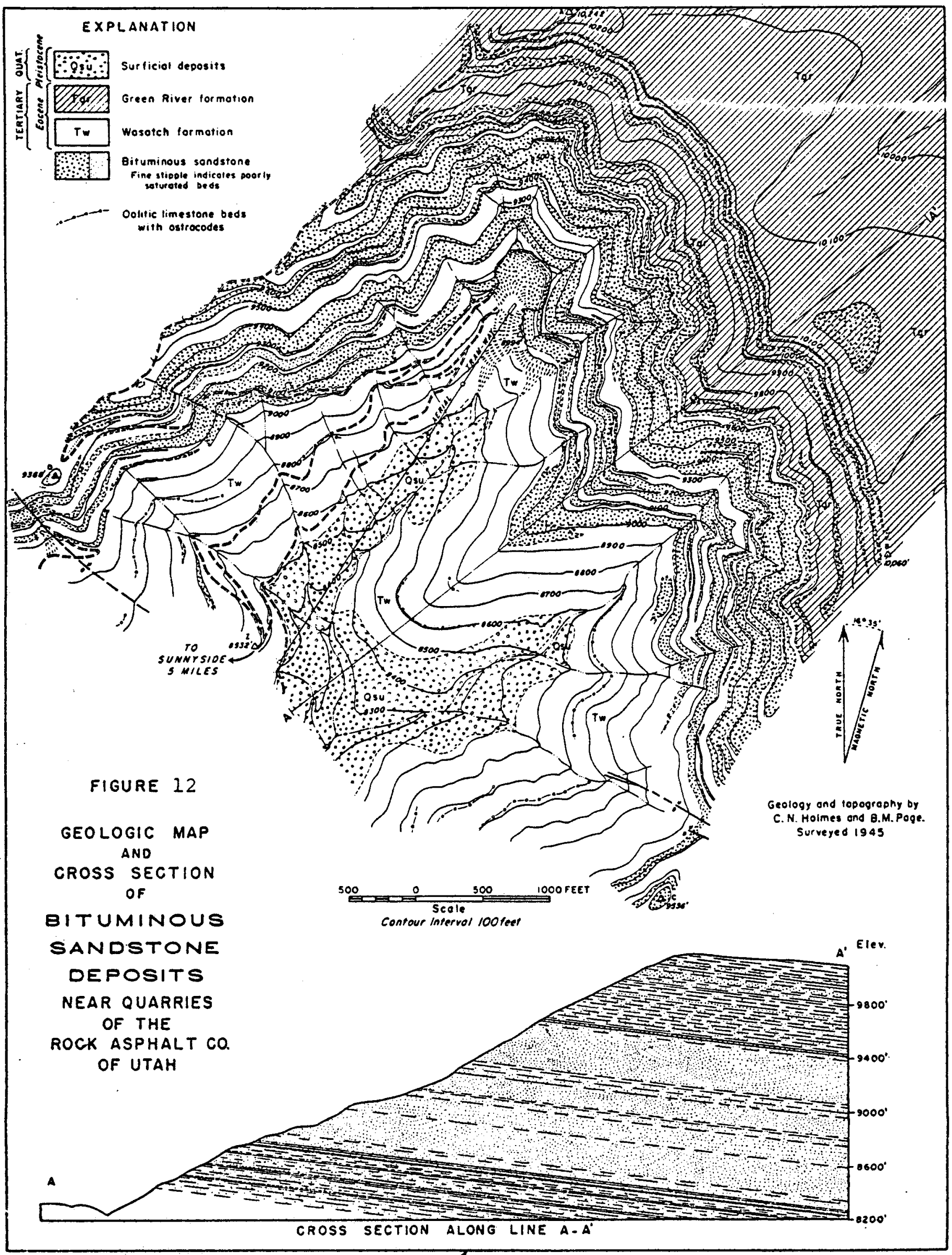


On July 13, 1970, Mr. Paul Burche11, Petroleum Engineer for the Oil, Gas, and Mining Conservation Commission, Department of Natural Resources, State of Utah, testified to Senator Moss (52) regarding experiments which had been conducted by shell Oil Company and Signal Oil Company at the Sunnyside tar sand deposit. He said, "The Shell oil Company drilled a five-spot program and they conducted two experiments, one in a huff and puff and one in a steam drive. The Signal oil Company drilled horizontal holes in the side of the bituminous sandstone cliff, three holes, and injected air and fire in the center and produced oil in the two outside ones."

Evidence of the Signal Oil Company fire flood experiment remains at the Sunnyside "rock asphalt" quarry. Several drill holes extend almost horizontally into the tar sand cliff face. Pools of solidified bitumen may still be found near the drill holes. Wooden framework which supported test equipment is still in place. $\mathrm{Mr}$. Cleon Feight (53) said that Signal oil recovered at least 90 barrels of bitumen during this fire flood test.

A large tar sand specimen weighing about 150 pounds was taken from the quarry for exhibit in the Minerals Science Building at the University of Utah. The surface of this specimen had several streamlets of bitumen on it which had seeped from the tar sand deposit.

During the October 17, 1974 visit to the sunnyside deposit, we drove to the top of the mountain ridge which divides the drainages into Whitmore Canyon on the west and Range Creek on the east. The elevation of Bruin Point on the ridge is 10,285 feet. There is a microwave transmission facility at Bruin Point. During a second visit to the Sunnyside deposit on June 6, 1975, this road was blocked by snow drifts.

Holmes ${ }^{(51)}$ et al named three areas in the sunnyside deposit where the overburden is shallow enough to consider surface mining. "Among these are the long ridge that forms the western boundary of the area shown on Figure 12; the saddle northwest of Bruin Point between Bruin Creek and South Fork of Dry Creek (Figure 11); and the area of broad outcrops on the divide between the heads of Left Fork and Slide Fork of Right Fork (Figure 11)." He also provides a cross section of the bituminous sandstone deposit near the quarries of the Rock Asphalt Company of Utah. This particular cross section shows about 680 feet of overburden (not counting the thin ore beds in this upper layer) and about 1160 feet of pay containing some barren zones. The overburden to pay ratio for this cross section is about 0.4. The pay zone in this figure is more than one-half mile wide and contains a cross section of about 500,000 square yards of oil sand. Similar cross sections extending for only one mile might contain about 0.9 billion cubic yards of pay and 0.34 billion cubic yards of overburden. This amount of 
pay would contain 430 million barrels of oil if the average oil saturation were 20 gallons per cubic yard. This small part of the Sunnyside tar sand reserve would provide feed for a 59,000 barrel per calendar day extraction plant for 20 years.

Such a 59,000 barrel per calendar day production facility would involve a huge surface mining operation. More than 123,000 cubic yards of tar sand would be mined each day and about 47,000 cubic yards of overburden would have to be relocated. This operation would be about four-tenths the size of Kennecott Copper Corporation's mining operation at Bingham, Utah. KCC has a daily target to move 324,500 tons of overburden and 108,000 tons of low grade copper ore. KCC uses 35 power shovels, 86 trucks, and a large number of railroad cars in their operation. The proposed Sunnyside mining operation should utilize the advantage of the high elevation of the deposit by moving both overburden and tar sand ore by a gravity flow operation. The aerial tramway used during the early history of tar sand mining at sunnyside was inefficient because the buckets had a very limited capacity. Conveyor belts would be much more efficient in moving large volumes of material from the mine site. But even these would be quite large since more than 85 cubic yards of ore per minute must be moved continuously.

Combined Metals Reduction Company of Salt Lake City(54) has offered 600 acres of Sunnyside tar sand property for sale at auction in Las Vegas, Nevada on April 3, 1975 and again on June 6, 1975. No bids satisfactory to the owners were made. The property overlaps the area surrounding the rock asphalt quarry that was mapped in 1945 by Holmes, et al. Combined Metals claims that this property offers a probable recovery of $187,500,000$ barrels of oil and contains more than 0.5 billion tons of tar sand. If one uses the weight of 1.77 tons per cubic yard, the calculated average oil content advertised is 28 gallons of oil per cubic yard. The property is adjacent to 900 acres owned by Shell Oil Company.

\section{Chemical Processing}

Shea and Higgins (33) found that Sunnyside tar sand contained more fines than their Asphalt Riage samples; consequently, bitumen recovery was only 90 percent for Sunnyside ore compared to 96 percent for Asphalt Ridge ore during their laboratory hot water separation tests. An aqueous solution of sodium silicate was added to increase the $\mathrm{pH}$ of the pulp to 8 to enhance the bitumen-sand separation. They found that bitumen recovered from Sunnyside tar sand contained only 0.50 weight percent sulfur and contained very little wax. A good quality asphalt was prepared in the laboratory by removing the lowest boiling 3.9 percent of the bitumen by vacuum distillation. 
Holmes, et al (51) indicate that the bitumen content of the Sunnyside tar sand varies up to more than 13 percent. Ritzma

indicates that the bitumen contains little sulfur. Two extracted bitumen samples showed contents of only 0.50 and 0.60 weight percent sulfur.

\section{Environmental Aspects}

Probably the most distinctive environmental feature of the Sunnyside deposit is the high altitude. The elevation at Bruin Point is 10,285 feet and the tar sand pay zones lie between 9,000 and 10,000 feet elevation. The terrain is mountainous and rugged, but there is sufficient precipitation for the growth of pine and quaking aspen trees. The re-establishment of native vegetation on reclaimed land should not be as difficult as at other deposits since annual precipitation is about 18 inches.

Water for tar sand chemical processing will have to be pumped to a significantly higher elevation from the Green River which flows less than ten miles east of the deposits' most eastern mineable extremity. Competition with other users of the Green River water will be keen.

The deposit includes significant areas of privately-owned land. some of the choicest mineable area is presently for sale.

\section{Conclusions}

The sunnyside tar sand deposit is rated by the writers to be the deposit most favorable for large scale surface mining. The principal reason for this rating is the thick pay zones.

Serious consideration should be given to the installation of a large surface mining and oil extraction facility on the sunnyside tar sand deposit. Even though the overburden thickness seems excessive, the average overburden to pay ratio is well below the cutoff ratio of unity used by tar sand operators in Athabasca. $(6)$

A detailed overburden thickness study is needed to identify areas where surface mining would be most economical. Also additional core drilling should be done to more accurately define the pertinent surface mining variables. 
TAR SAND TRIANGLE

Utah's largest tar sand deposit is known as the "Tar Sand Triangle." The Tar Sand Triangle covers more than 200 square miles in central southeast Utah. It lies within Townships 29 , $30,30.5,31,32$, and 33 South, Ranges 14, 15, 16, and 17 East, in Garfield and Wayne Counties. The Green and Colorado Rivers lie east of this huge tar sand deposit and the Dirty Devil River lies on the west. The east boundary of the deposit is very close to Lake Powell on the Colorado River and the west boundary of Canyonlands National Park. About forty percent of the deposit lies within the Glen Canyon National Recreation Area. The National Park Service has jurisdiction over these two areas. The U.S. Bureau of Land Management has jurisdiction over most of the remaining area of the deposit. Several smaller areas of the deposit lie on State of Utah lands.

\section{Geology}

Ritzma(42) said, "The Tar Sand Triangle deposit appears to be the residue of a gigantic oil field formed by the updip pinch out of the Permian white Rim Sandstone draped across the northwest plunge of the Monument Upwarp of Southeast Utah." Utah Geological and Mineral Survey Map $33(1)$ indicates that the oil apparently originated in organic permian or possibly Pennsylvanian rocks. Later the oil migrated upward via faults, fractures, and joints and penetrated into the uppermost Permian and lower Triassic sandstones. The formation of the canyons on each side of the deposit resulted in the formation of outcrops on both the updip and downdip sides of the huge deposit. This erosion removed the upward water drive and released the lighter hydrocarbons of the oil field to the atmosphere. With pressure from below released, considerable migration downward later occurred due to gravity.

Six areas within the Tar Sand Triangle have been named: (1) Elaterite Basin, (2) Red Cove, (3) Teapot Rock, (4) Fault Point, (5) The Cove, and (6) Hatch Canyon. The geologic formations and relative location of these areas are as follows. The Elaterite Basin lies in Township 30 South, Range 17 East, at the northeast corner of Tar sand Triangle. The tar sand deposits of the Elaterite Basin lie in the White Rim Sandstone portion of the Cutler Formation (Permian Age). The Red Cove area is just south of the Elaterite Basin and its deposits are in both the White Rim and the Cedar Mesa Sandstone members of the Cutler Formation. The Teapot Rock area is in Township 31 South, Range 16 East, at the 
mideastern edge of the triangle. The Teapot Rock tar sand lies in the White Rim and the Cedar Mesa Sandstone members of the Cutler Formation. Fault Point is located southwest of Teapot Rock at the bottom of the triangle in Township 32 South, Ranges 15 and 16 East. Fault Point tar sands are in the white Rim and Cedar Mesa Sandstone also. The Cove area is just west of Fault Point in Township 32 South, Range 15 East. The Cove area includes smaller areas bearing the names Cove, Fiddler Cove Canyon, French Seep, North Hatch Canyon, Orange Cliffs, and South Hatch Canyon. The geologic formations in which these tar sand deposits occur are the White Rim Sandstone in the Cutler Forma. tion (Permian), the Moenkopi Formation (Triassic), and the Shinarump Conglomerate, a basal member of the Chinle Formation (Triassic). More than 99 percent of The Cove's tar sand lies in the White Rim Sandstone. The Hatch Canyon Tar Sand Triangle area is on the west edge of the triangle in Township 31 South, Range 14 east. Its tar sand lies in the same formations as The Cove Area.

\section{Surface Mining}

Much of the huge Tar sand Triangle tar sand deposit can be surface mined although overburden thickness varies from zero to more than 1500 feet over the more than 200 square mile area of the deposit. There is only one pay zone or tar sand vein and it varies in thickness from five to three hundred feet. In his December $1973 \mathrm{speech}$ to the Interstate Oil Compact Commission, Ritzma (4.2) described the Tar sand Triangle as follows: "The area is exceedingly rugged and the deposit is found exposed along nearly vertical cliffs and extends downdip beneath an intricately dissected plateau. Access to exposed areas is difficult and is easiest from the plateau above where a sizeable number of coreholes and wells have intercepted the saturated sandstone at various depths and distances from the outcrop."

Mr. James H. Wardle of Springville, Utah, has leased a State school section (640 acres) at Fault Point one-half mile from lake Powell. The tar sand pay zone is 80 feet thick and visible in the cliff face on his lease. At this location there is 30 feet of overburden and another 30 feet of barren sandstone below the pay zone. To reach his lease northeast of the confluence of the Colorado and Dirty Devil Rivers, you must travel about 25 miles over unimproved road to go six miles "as the crow flies".

Based on Iimited data, it appears that the Tar sand Triangle deposit is quite lean. The bitumen content of the pay zone appears to be less than 15 gallons per ton of tar sand. Although the sandstone is fine-grained, it is quite porous and permeable. Samples gathered by the writers from various outcrop locations 
indicate that drilling and blasting will be required to surface mine this largest of the Utah tar sand deposits.

\section{Chemical Processing}

Both in-situ and surface mining methods may be used to recover bitumen from the Tar Sand Triangle deposits since overburden thickness varies from zero to more than 1500 feet. It is probably not economical to move more than 100 feet of overburden for surface mining processing; however, this depends upon the market price of the bitumen and the thickness of the pay zone.

The relatively high sulfur content of Tar sand Triangle bitumen may be a significant deterrent to the early development of this huge deposit. Fifteen oil samples reported by Wood and Ritzma (37) had an average sulfur content of 3.56 weight percent. The Uinta Basin tar sand deposits all show well below one percent sulfur. High sulfur content of oil refinery raw material necessitates additional processing equipment for sulfui removal and the use of expensive metal alloys for corrosion protection.

The Tar Sand Triangle samples reported by Wood and Ritzma had oil contents from 1.3 to 9.8 percent. The extracted oil had an average specific gravity of 1.043 .

Iittle data have been found regarding test work on the Tar Sand Triangle deposit. The Oil Development Company of Utah has filed a formal request to perform an in-situ combustion pilot test in the Gordon Flat area of Wayne County. This firm's 16,640 acre tract lies in the Glen Canyon National Recreational Area. A copy of the mining application for this test was obtained from the U.S. Geological survey office in Salt lake City.

\section{Environmental Aspects}

The arid climate in the Tar sand Triangle area is a major problem. The plateau only receives from six to ten inches of precipitation per year and most of this occurs in the winter and early spring. The annual water runoff is only about one inch. There is little vegetation or animal life in the area. Reclamation of surface mined land will be difficult if the re-establishment of vegetation is required.

Ample water for tar sand resource development is nearby in the Green and Colorado Rivers on the east of the deposit and the Dirty Devil River on the west. At the confluence of the Colorado and the Dirty Devil, the Dirty Devil has a flow of 79,000 acre feet per year, and the Colorado's flow is well over 8 million acre feet. The allocation of water from these rivers for tar sand recovery will be a serious problem since all of utah's 
share of the Upper Colorado River Basin water $(1,400,000$ acre feet per year) is either in use $(800,000$ acre feet) or has already been allocated $(600,000$ acre feet) for other purposes. This tar sand resource cannot be developed unless allocations of presently unused water from one of these rivers can be made available in some way.

Another serious "people problem" is the ownership of the Tar Sand Triangle land. About forty percent of the deposit lies on Glen Canyon National Recreational Area land under the jurisdiction of the National Park Service. Much of the remaining area is on Bureau of Land Management land. Prior to any extensive tar sand resource development in this area, it will be necessary for the Federal Government to issue leases for such use of the land. There are some small areas owned by the State of Utah which presumably can be made available for experimental demonstration type installations.

The remoteness of the Tar sand Triangle from a market for the bitumen is another serious problem. It would be quite costly to transport this semi-solid to the salt Lake City area for refining and quite illogical to build a large refinery in an unpopulated area near Lake Powell.

\section{Conclusions}

Although the Tar Sand Triangle is larger than the sum of all the other tar sand deposits in Utah, as far as oil reserve in place is concerned, the writers rank it the second best prospect for surface mining and oil extraction. The sunnyside deposit was ranked first due to its thick pay zones, high oil content, and low sulfur content.

An overburden thickness study should be made to identify speci-fic areas in the large Tar sand Triangle deposit that can be surface mined. After mineable areas have been identified, a core drilling program should be initiated to further evaluate this large oil resource. 


\section{CONCLUSIONS}

1. Only six of the more than 50 tar sand deposits in the Intermountain west contain more than one billion barrels of oil in place. All of these six deposits are located in Eastern Utah in semi-arid mountainous terrain. A surface mineable reserve of at least one billion barrels of oil is required to feed a 100,000 barrel per day oil extraction plant for a 20 year period. Although these six tar sand deposits contain a total of 25 billion barrels of oil, only three of them, sunnyside, Tar Sand Triangle, and P.R. Spring, can possibly contain one billion barrels of oil that is surface mineable. The names of the six deposits arranged in descending order of desirability for large scale surface mining oil recovery operations are as follows: Sunnyside, Tar Sand Triangle, Asphalt Ridge, P.R. Spring, Circle Cliffs and Hill Creek.

2. Table IX presents a summary of some pertinent surface mining variables for the six largest deposits. Column one is the largest area of the range of areas presented for each deposit by the Utah Geological and Mineral Survey in their Map 33(1). Columns two, pay thickness, and three, oil reserve, were taken from Map 33 without modification. Since overburden thickness for each deposit varies from zero at outcrops to more than 300 feet according to Map 33, this variable has been omitted. Column four, millions of barrels of oil per square mile, was calculated by dividing column three by column one. Column five, average pay thickness, was calculated by assuming that the average oil saturation of each pay zone was 20 gallons of oil per cubic yard of pay. The tar sand deposits in Table IX are listed in descending order of overall desirability for large scale surface mining.

3. The Sunnyside deposit has been ranked number one because it has (1) a good surface mineable oil reserve, (2) excellent pay thickness, (3) high oil saturation, (4) moderate overburden to pay ratio, (5) low bitumen sulfur content, and (6) good access by road and rail. Although overburden thickness may seem excessive at sunnyside, the average overburden to pay ratio is well below unity at the south end of the deposit where the pay zones are thickest.

4. The Tar Sand Triangle tar sand deposit has been ranked as the second most desirable deposit for surface mining because it has (1) the largest total oil reserve and probably the largest surface mineable oil reserve, (2) the thickest average pay, and

(3) good water access. Negative aspects for this deposit are

(1) high bitumen sulfur content, (2) reclamation difficulty, and

(3) remoteness from roads, rail and product markets. 
Table IX

SURFACE MINING VARIABLES

\begin{tabular}{|c|c|c|c|c|c|}
\hline Deposit & $\begin{array}{c}\text { Area } \\
\text { Sq. Miles }\end{array}$ & $\begin{array}{c}\text { Pay } \\
\text { Thickness } \\
\text { Feet }\end{array}$ & $\begin{array}{l}\text { Oil Reserve } \\
\text { Billion bbls. }\end{array}$ & $\begin{array}{l}\text { Million bbls. } \\
\text { Per Sq. Mile }\end{array}$ & $\begin{array}{c}\text { Average Pay } \\
\text { Thickness } \\
\text { Feet }\end{array}$ \\
\hline Sunnyside & 90 & $15-550$ & $3.5-4.0$ & 44 & 90 \\
\hline Tar Sand Triangle & 230 & $5-300+$ & 16 & 70 & 142 \\
\hline Asphalt Ridge & 25 & $10-135$ & 1.05 & 42 & 85 \\
\hline P.R. Spring & 270 & $10-80$ & $4 \cdot 0-4 \cdot 5$ & 17 & 34 \\
\hline Circle cliffs & 28 & $5-310$ & 1.31 & 47 & 96 \\
\hline Hill Creek & 125 & $5-35$ & 1.16 & 9 & 19 \\
\hline
\end{tabular}

* Based on an average oil concentration of 20 gallons per cubic yard. 
5. The Asphalt Ridge deposit has been ranked third because it has (1) good oil saturation, (2) good pay thickness, (3) excellent water availability, (4) low sulfur content, and (5) good access to roads and markets. It would have ranked first except for the idct that it is a comparatively small deposit with excessive overburden on more than 85 percent of the oil reserve. It is the only deposit studied which can be surface mined effectively without drilling and blasting. The Asphalt Ridge deposit can support one extraction plant having a maximum capacity of about 17,000 barrels of oil per day. The plant should be located near the center of the deposit to limit maximum ore haulage distance to about seven miles.

6. The P.R. Spring tar sand deposit has been ranked fourth by the writers because it has (1) a good oil reserve, (2) good oil saturation, (3) low overburden thickness at the northeast and south ends of the deposit, and (4) low bitumen sulfur content. Table IX indicated that pay thickness is poor. A significant amount of core drilling has been done and published. Core data indicate a wide separation of the two to six pay zones by barren material.

7. The Circle cliffs tar sand deposit has been ranked fifth because it has (1) poor oil saturation, (2) a high silt and clay content, and (3) high bitumen sulfur content. This deposit has thick pay and low overburden thickness.

8. The Hill Creek tar sand deposit has been given the sixth or lowest rating because it has (1) low oil saturation, (2) the lowest average pay thickness, and (3) high overburden thickness.

9. Mountain-top removal is expected to be the most extensively used surface mining method to recover oil from Utah tar sand since the large deposits all lie in mountainous terrain. In many cases the pay zones outcrop on both sides of a mountain.

10. Based on limited consolidation data, drilling and blasting of both overburden and pay zones may be required at each of the large Utah tar sand deposits with the possible exception of the Asphalt Ridge deposit.

11. A preliminary equipment study indicates that draglines will be favored for moving overburden at the tar sand deposits studied. Trucks will probably be favored over railroad cars and conveyors for moving the ore to the extraction plant. No generalization can be made regarding the best equipment for mining the tar sand ore.

12. The surface mining operation required to supply tar sand feed to a 100,000 barrel per day oil extraction plant is mind boggling. 
The mine would be as large as the Bingham Canyon, Utah, Kennecott Copper open pit which is the largest surface mining operation in the world. Careful planning of the mining operation is required since mining costs may be as much as forty percent of the total cost of producing a low quality oil from a low grade ore containing only ten percent oil. The following basic factors should be considered to improve the economics of oil recovery from Utah tar sands:

a. Select a mine site containing a large tai sand reserve, containing a high oil content and having a low overburden to pay ratio. Remoteness from crude oil markets is of secondary importance since in a large operation, the bitumen can be coked, hydrogenated and pipelined.

b. Minimize the cost of mining by determining the most economical equipment type, equipment size, and mining method for a particular open pit mine.

c. Minimize the cost of transporting the ore from the mine to the processing plant. Consider conveying (gravity if possible) instead of truck or rail haulage. If scrapers are used, employ driveover dump stations so that ore-laden scrapers can unload without stopping.

d. Minimize the cost of handling the ore and sand during extraction. Avoid rapid agitation unless it can be justified by reduced equipment size. Recognize that mining tar sand ore requires large shear forces and that the sand in the ore is very abrasive.

e. Operate both the mine and the extraction plant day and night and continuousiy the year around to reduce equipment size and the need for many multiple units. Utah winters should permit year around mining.

f. Minimize the cost of transporting the spent sand from the processing plant. Possibly overburden alone could be used to reclaim mined out areas and spent sand could be used for fill in canyons near the process plant. Conveying the spent sand may be more economical than trucking it.

13. Water availability for tar sand resource development in eastern Utah is a serious problem. Although water is available in rivers within ten miles of the six large deposits, competition for the limited water supply will be keen, with many more potential uses being proposed than there is water available. Other potential water users include coal-burning electric power plants, oil shale development, coal gasification, Bureau of Land Management projects, Forest Service Wildlife and Fisheries 
projects, new agricultural and municipal uses, and the Wild and Scenic Rivers Act. Coal-burning electric power plants are expected to receive the major portion of the available water because they are developing more quickly and require less technological sophistication than other large water consumers.

14. Due to the scarcity of water in eastern Utah where the large tar sand deposits are found, chemical processing methods which employ a solvent are certainly of interest. Solvent extraction processes require much less water than the Clark hot water process which is in use by GCOS at Athabasca, Alberta, Canada. It is believed that solvent processes can be economically competitive with water processes if solvent losses are minimized. The adequate recovery of solvent from spent sand is the most challenging and critical problem in solvent extraction processes.

15. Much additional resource evaluation work needs to be done on the six largest tar sand deposits in Utah. The location of outcrops is probably quite complete. Some mapping, stratigraphic sectioning, and core drilling has been done, but more is needed. Resource evaluation work has been greatest at the P.R. Spring and Asphalt Ridge deposits. Considerable resource evaluation work remains to be done at the other four large deposits. 


\section{RESEARCH RECOMMENDATIONS}

Additional research is needed to encourage the early commercial recovery of oil from the Utah tar sand resource. The following research projects are recommended by the writers:

1. The Sunnyside tar sand deposit has been identified as the deposit having the greatest overall potential for large scale surface mining in the united states. It is recommended that a detailed resource evaluation study be pursued to more completely evaluate the surface mining possibilities of this deposit. Visits should be made to the oil companies who have drilled holes north and east of the Book Cliff outcrops in an effort to obtain information. Additional mapping and stratigraphic sectioning work should be done in the field in conjunction with the Utah Geological and Mineral Survey and a plan formulated for additional core drilling. The formulated core drilling program should be executed and a mining system should be designed. If mining is found to be feasible, consideration should be given the initiation of an overburden removal program while a tar sand processing plant is being designed and built.

2. The Tar Sand Triangle deposit has been ranked by the writers as the second most desirable deposit for large scale surface mining. Much of the single thick pay zone is covered by excessive overburden; however, it is recommended that a detailed overburden to pay ratio study be made to identify specific surface mineable areas in this huge deposit. An exploratory core drilling program is recommended to provide badly needed resource evaluation data in the areas that are believed to be surface mineable.

3. Although only twelve percent of the oil reserve of the Asphalt Ridge tar sand deposit is surface mineable, this deposit has an important role to play in the early commercial development of Utah tar sand resources. This deposit can support only one 17,000 barrel per day extraction plant. It is recommended that Asphalt Ridge be utilized as a testing ground for early pilot plants and demonstration units since it has (a) the most favorable accessibility to facilities and product markets, (b) good oil saturation, (c) good pay thickness, (d) excellent water availability, (e) low sulfur content, and (f) minimal land ownership problems. The operation of demonstration plants is vital to develop the Utah tar sand technology so that it will be available for the design of future commercial scale plants. 
4. A significant number of core holes have been drilled and the information published on the fourth ranking P.R. Spring deposit. It is not recommended that additional coring be done at this time since resource evaluation effort should be concentrated on other deposits. An overburden thickness and overburden to pay ratio study should be made, however, to identify the best surface mineable areas in this large deposit.

5. It is recommended that the extracted oil from the six giant deposits be studied as a possible supplement or substitute for commercial asphalt presently used in road paving material. The Utah State Department of Transportation has adequate laboratory facilities to perform the necessary tests on both the oil and the paving material produced using the oil. It is possible that Utah road maintenance may be reduced by the proper use of tar sand oil from one of these deposits as a substitute for asphalt in road paving material.

6. It is recommended that a laboratory extraction study be made using low cost solvents and samples from each of the six giant deposits since competition for water will be keen in the arid regions of the Utah tar sand deposits. Of particular interest would be a study of the extraction of Circle cliffs tar sand with a low specific gravity solvent such as hexane. This deposit has thick pay zones and low overburden thickness, but the high siltstone and mudstone content of the ore will probably prevent economical extraction using water. Fine mineral material is more easily separated from a low specific gravity solvent than from water.

7. It is recommended that a detailed study be made of the characteristics of the overburden, the tar sand ore, and the extracted oil from each of the six giant Utah deposits. J.W. Bunger has done and is continuing to work on the characterization of the oil. This work must be extended to all six deposits and to overburden and ore characteristics to accurately identify the differences between the deposits. The results obtained from this study should be compared with similar data obtained from the Alberta, Canada, deposits.

8. It is recommended that a mining equipment study applicable to the surface mining of Utah tar sand be made. This study should include the optimum cost and selection of both excavating and transportation equipment. The recommendations from this study may be different for each of the six giant tar sand deposits.

9. It is recommended that a master water management plan be formulated for eastern Utah to obtain the greatest long-range benefits from the available unused Upper Colorado River Basin water. Tar sand resource development should be given appropriate water allocations since oil recovery from tar sand is 
probably more economical than oil recovery from oil shale or from coal liquefaction.

10. It is recommended that research on the Hill creek tar sand deposit be given a low priority even though the data available on the deposit are quite limited since the deposit has been ranked sixth as a large scale surface mining prospect.

11. It is recommended that a review be made of known tar sand oil extraction methods. It is also recommended that preliminary extraction plant designs and cost estimates be prepared for the more favorable extraction methods identified during the methods review.

12. It is recommended that preliminary environmental impact studies be made on each of the six giant tar sand deposit areas.

13. It is recommended that mined land reclamation studies be made on each of the six giant tar sand deposit areas. 


\section{REFERENCES}

1. Ritzma, H.R. Oil-Impregnated Rock Deposits of Utah. Utah Geological and Mineralogical Survey Map 33. Salt Lake City, Utah 1974.

2. Kennecott Copper Corporation. "Mine-Plant Fact SheetJanuary 1, 1975."

3. Oblad, A. and Seader, J.D. Recovery of Oil from Utah's Tar Sands. Proposal to NSF-RANN. University of Utah. April 30, 1974 .

4. Personal Communication with Mr. Eugene Dalton, President of Arizona Fuels Corp., on February 8, 1976.

5. Cottrell, J.H. "Development of an Anhydrous Process for Oil-Sand Extraction," in Carrigy, M.A., ed., The K.A. Clark Volume, Edmonton: Res. Council of Alberta, october, 1963 .

6. Camp, F.W. The Tar Sands of Alberta, Canada, Second Edition. Denver: Cameron Engineers, Inc., 1974.

7. Personal Communication with Dr. Alfred R. Globus, President of Guardian Chemical Corporation, on February 17, 1976.

8. Personal Communication with Dr. Wayne I. Wahlquist, President of Minerals Research Corp., Box 216, Ogden, Utah, on April 24, 1975 .

9. Cameron Engineers, Inc. Synthetic Fuels. March, 1975, pp. 3-1 to 3-3.

10. Personal Communication with Mr. Robert M. Lowe, Sohio Petroleum Company, on January 20, 1976.

11. Personal Communication with Mr. J. W. Bunger on January 14, 1976.

12. Personal Communication with Mr. Benjamin J. Gikis of Stanford Research Institute on June 6, 1975.

13. Personal Communication with Mr. Glenn Peterson of Bingham Mechanical and Metal Products Corp., Idaho Falls, Idaho, on March 3, 1976. 
14. Personal Communication with Mr. Lloyd Johanson, President of LDK, Inc., on September I, 1975.

15. Rampton, C.L., Governor of Utah. "Water-Key to Utah's Future Development." Speech given at University of Utah, Salt Lake City, Utah, June 6, 1975.

16. Personal Communication with Dr. Val Finlayson, Research Director, Utah Power \& Light Company, on March 18, 1975.

17. Personal Communication with Dr. Cyrus McKel1, Director of the Institute for Land Rehabilitation, Utah State University, Logan, Utah, on November 11, 1974.

18. Deseret News, Salt Lake City, Utah. July 23, 1975, p. B8.

19. Gill, D. "Utah Oil Sands Could Be a Solid Investment." Western Oil Reporter. December 1974, p. 27.

20. Great Canadian Oil Sands Ltd. Annual Report. 1974.

21. Roberts, P.V. "Comparative Economics of Tar Sand Conversion Processes," presented at the l60th American Chemical. Society National Meeting (Chicago, September 13-18, 1970), ACS, Div. Fuel Chem., Preprints 14, 3:98 (1970).

22. Baillie, R.A., and Mertes, T.S. "Development and Production of Oil from the Athabasca Tar Sands," pp. 241-27I of Proceedings of the Southwestern Legal Foundation, Exploration and Economics of the Petroleum Industry, Vol. 6, M. Bender Company, New York, 1968.

23. Gill, D. "Oil Sands Operations May Flourish in Alberta; They May Succeed in Utah on a Lesser Scale," Western Oil Reporter. November, 1974, p. 48.

24. Western Oil Reporter. August, 1974, p. 8.

25. Peters, M.S., and Timmerhaus, K.D. Plant Design and Economics for Chemical Engineers, Second Edition. New York: McGraw-Hill BOOK Co., 1968, P. 107.

26. Van De Graaf, D., Executive Director of the Utah Petroleum Association. "Oil and Energy Development in Utah." American Inst. of Chemical Engineers, Great Salt Lake Section Meeting, Salt Lake City, Utah, March 13, 1975.

27. Personal Communication with John Oakason, President of Petroleum Investment and Research, on July 11, 1975.

28. Hottel, H.C. and Howard, J.B. New Energy Technology-Some Facts and Assessments. Cambridge: MIT Press, 1972. 
29. Iammartino, N.R., "Tar Sand Projects Stuck," Chemical Engineering. February 17,1975 , pp. 44-48.

30. Shea, G.D. and Higgins, R.V. Laboratory Study of the HotWater Process for Separating Hyarocarbons from Surface Deposits of Bituminous Sandstones Near Edna, California. Bureau of Mines RI 4246. Washington: Government Printing Office, 1948.

31. Bennett, Paul. "Mining the Oil Sands of Canada." BIG, 30, No. I (1974), pp. 3-7.

32. Covington, R.E. "Bituminous Sandstone and Limestone Deposits of Utah." Oil and Gas Possibilities of Utah, Re-Evaluated. Ed. Arthur L. Crawford. Utah Geological and Mineralogical Survey Bulletin 54. Salt Lake City: UGMS 1963.

33. Shea, G.B. and R.V. Higgins. Separation and Utilization Studies of Bitumens from Bituminous sandstones of the Vernal and Sunnyside, Utah, Deposits. Bureau of Mines RI 4871. Washington: Government Printing office, 1952.

34. The authors visited the Uintah County Asphalt Pit and made observations and inquiries on August 28, 1974.

35. Sohio Petroleum Company, July 1, 1974, Notice of Intention to Commence Mining Operations to $\mathrm{Mr}$. Cleon Feight, Director, Board of Oil and Gas Conservation, 1588 West North Temple, Salt Lake City, Utah.

36. Sohio Petroleum Company, "Proposed Plan for Mining and Processing Operations," from public hearing held in Vernal, Utah, August 28,1974 .

37. Wood, R.E. and Ritzma, H.R. Analyses of Oil Extracted from oil-Impregnated Sandstone Deposits of Utah. Utah Geological and Mineralogical Survey Special studies 39. Salt Lake City: UGMS, 1972.

38. Personal Communication on July 3, 1975, from Mr. Robert Lowe, Sohio Tar Sand Project Manager.

39. Kayser, R.B. Bituminous Sandstone Deposits of Asphalt Ridge. Utah Geological and Mineralogical Survey special Studies 19. Salt Lake City: UGMS, 1966.

40. Spieker, E.M. Bituminous Sandstone Near Vernal, Utah. U.S. Geological survey Bulletin 822-C. Washington: Government Printing office, 1930 .

41. Covington, R.E. "Bituminous Sands and Viscous Crude Oils." Proceedings of the First Intermountain Symposium on Fossil Hydrocarbons. Eds, B.J. Pope, L.V. Harry and L.B. Lyon. SaIt Lake City: Brigham Young University, 1964, p. 370 . 
42. Ritzma, H.R. "Commercial Aspects of Utah's Oil-Impregnated Sandstone Deposits." Paper presented to joint session of Interstate oil Compact Commission, New Orleans, December 3, 1973 .

43. Ritzma, H.R. "Petroleum Potential of Utah." Paper presented to American Association of Petroleum Geologists, Rocky Mountain Section, Albuquerque, New Mexico, February 26, 1969.

44. Personal Communication on August 25, 1975 with Mr. Ron J. Hollberg, Jr., President of Arjay Oil Company.

45. Personal Communication with Dr. Dale E. Slade of Fort Duchesne, Utah, on October 24,1974 .

46. Personal Communication with Dr. Thomas E. Sawyer on November $19,1974$.

47. Marchant, L.C., L.A. Johnson and C.Q. Cupps. Properties of Utah Tar Sands - Threemile Canyon Area, P.R. Spring Deposit. Bureau of Mines RI 7823. Washington: GPO, 1974.

48. Bunger, J.W. Characterization of a Utah Tar Sand Bitumen. American Chemical Society, Division of Fuel Chemistry Preprint, 19, No. 2 (1974), 231-241.

49. Gwynn, J.W. Instrumental Analysis of Tars and Their Correlations in Oil-Impregnated Sandstone Beds, Uintah and Grand Counties, Utah. Utah Geological and Mineralogical Survey Special studies 37. Salt Lake City: UGMS, 1971.

50. U.S. Department of the Interior, Geological Survey, Office of Water Data Coordination, Catalog of Information on Water Data, 1972 Edition. (This reference refers to sources of specific stream flow data documents which were utilized.)

51. Holmes, C.M., B.M. Page and P. Averitt. Geology of the Bituminous Sandstone Deposits Near Sunnyside, Carbon County, Utah. U.S. Geological Survey OIl and Gas Investigation Preliminary Map 86. Washington: Government Printing office, 1948 .

52. Moss, Senator Frank $E$. in Tar Sands Hearing Before the Subcommittee on Minerals, Materials and Fuels of the Committee on Interior and Insular Affairs, United states senate. Ninety-First Congress, Second Session. JuIy 13, 1970. Salt Lake City, Utah.

53. Personal Communication on October 21, 1975, with Mr. Cleon Feight, Director of the Oil, Gas and Mining Conservation Commission, Department of Natural Resources, State of Utah. 
54. Western Oil Reporter. May 1975, p. 52.

55. Cupps, C.W., C.S. Land and L.C. Marcnant. Field Experiment of In Situ Oil Recovery from a Utan Tar Sand by Reverse Combustion. U.S. Bureau of Mines Report of Investigation paper presented at the American Institute of Chemical Engineers Meeting in Los Angeles, California, iNovemier 20,1975 . 


\section{BIBLIOGRAPHY}

* Abbott, Ward, "Tertiary of the Uinta Basin." Guidebook to the Geology of the Uinta Basin. Ed. Otto G. Seal. Salt Lake City: Intermountain Assn. Petroleum Geologists, 1957.

Allen, A.R. "The Mining and Abstraction of Bitumen from tne Athabasca Tar Sands." The Canadian Mining and Metallurgical Bulletin, 67 , No. $746(\overline{1974)})$ 97-108.

Alternative Sources of Water for Prototype Oil Snale Development, Colorado and Utah. Salt Lake City: Bureau of Reclamation, Upper Colorado Region, 1974.

Austin, Lloyd $H$. and Gaylord V. Skogerboe. Hydrologic Inventory of the Uintah Study Unit. Utah Division of Water Resources. Logan: Utah Water Research Laboratory, Utah State University, 1970 .

----. Water Management Alternatives in the Uinta Basin. M.S. Thesis in Civil Engineering. Logan: Utah State University, 1970 .

Baer, James L. and Eugene Callaghan, eds. Plateau - Basin and Range Transition Zone, Central Utah, 1972. Utah Geological Assn. Pulication 2. Salt Lake City: Utah Geological Assn., 1972 .

Ball, James Ogden. "Hydrocarbons of the Uinta Basin of Utah and Colorado: Survey of Bitumen Analyses and Extraction Methods." Quarterly of the Colorado School of Mines, Vol. 39, No. I, Golden: Colorado School of Mines, 1944.

Barb, Clark F. "Hydrocarbons of the Uinta Basin of Utan and Colorado: Review of Geology and Fieldwork." Quarterly of the Colorado school of Mines, Vol. 39, No. I, Golden: Colorado School of Mines, 1944.

Barton, Blaine and Donald stowell. A Feasibility study of a Tar Sand Processing Plant. Paper prepared for Chemical Engineering 683, Advanced Plant Design, Brigham Young University, June $19,1975$. 
Bennett, Harold J., et al. An Economic Appraisal of the Supply of Copper from Primary Domestic Sources. Dept. of the Interior, Bureau of Mines Information Circular No. 8598. Washington: Government Printing OFfice, 1973.

Bennett, Paul. "Mining the Oil Sands of Canada." BIG, 30, No. $1(1974), 3-7$.

Bowman, C.W. "Molecular and Interfacial Properties of Athabasca Tar Sands," Seventin world Petroleum Congress Proceedings, vol. 3. Essex, England: Elsevier, 1967, pp. 583-604.

Bowman, Joe L. Oil Impregnated Sandstones Between Dirty Devil and colorado and Green Rivers, Garfield and Wayne counties, Utah, (abs.). American Assn. Petroleum Geologists Bulletin, 53, No. I (1969), 218 .

Brief, Water for Oil Shale - White River. Salt Lake City: Dept. of Natural Resources, State of Utah, Division of Water Resources, December 17, 1973.

Bunger, J.W. Annotated Bibliography on North American Tar Sands, May, 1974. Memorandum to S.M. Dorrence, second quarterly report for 1974. Bureau of Mines, Laramie, Wyoming, July 2, 1974 .

----. Characterization of a Utah Tar Sand Bitumen. American Chemical Society, Division of Fuel Chemistry Preprint, 19, No. 2 (1974), 23I-24I.

----. Characterization of a Utah Tar Sand Bitumen (revised). Journal article for inclusion in symposium proceedings to be published in Advances in Chemistry Series, American Chemical Society, Laramie: Bureau of Mines, 1974.

Bureau of Community Development. Critical Issues in Utan's Future. "A series of presentations before the Higher Education, Government, Research and Industry Committee." Salt Lake City: Bureau of Community Development, Septemier, 1975.

Buss, Walter R. Bibliography of Utan Geology to December 31, 1950. Utah Geological and Mineralogical Survey Bulletin 40 . Salt Lake City: Utah Geological and Mineralogical Survey, 1951 .

Byrd, William D., II. P.R. Spring Oil-Impregnated Sandstone Deposit Uintah and Grand Counties, Utah. Utah Geological and Mineralogical Survey Special studies 31. Salt lake city: Utah Geological and Mineralogical Survey, 1970. 
* Cambel, Ali B. Energy Research and Development and National Progress. Washington, D.C.: Government Printing Office, 1964.

Cameron Engineers, Inc., Synthetic Fuels, September 1974 .

Cameron Engineers, Inc., Synthetic Fuels, March 1975.

Camp, F.W. "Tar Sands," Kirk-Othmer Encyclopedia of Chemical Technology, 1963, XIV, 682-732.

---. The Tar Sands of Alberta, Canada, Second Edition. Denver: Cameron Engineers, Inc., 1974.

Carrigy, M.A. Athabasca Oil Sands Bibliography (1789-1964). Research Council of Alberta Preliminary Report 63-5. Edmonton: Research Council of Alberta, 1965.

--- , ed. The K.A. Clark Volume. Edmonton: Research Council of Alberta, october, 1963 .

---. "The Physical and Chemical Nature of a Typical Tar Sand: Bulk Properties and Behavior." Seventh World Petroleum Congress Proceedings, Vol. 3. Essex, England: Elsevier, 1967, pp. 573-582.

Cashion, W.B. "Other Bituminous Substances." Mineral and Water Resources of Utah. Utah Geological and Mineralogical Survey Bulletin 73. Washington: Government Printing Office, 1964, reprinted 1969.

Catalog of Information on Water Data Edition 1972, Water Resources 14 (Upper Colorado). Dept. of the Interior, Geological Survey, Office of Water Data Coordination. Washington: U.S. Geological Survey, 1973.

Chaapel, Dean S. "The Oil Sands Fulfill Their Promise." Our Sun, 39 , No. $3(1974), 2-6$.

Cheney, Harry A. and William E. Savage. Process for Extracting Tar from Tar Sand. Patent No. 3,553,099, U.S. Patent Office, Patented January 5, 1971.

Childers, Barbara S. and Bernice Y. Smith, eds. Abstracts of Theses Concerning the Geology of Utah to 1966 . Utan Geological and Mineralogical survey Bulletin 86 . Salt Lake City: Utah Geological and Mineralogical Survey, 1970. 
Cohenour, Robert E. "Fossil Hydrocarbons of the Tri-state Basins." Proceedings of the First Intermountain Symposium on Fossil Hydrocarbons, Eds. B.J. Pope, J.V. Harry, and L.B. Lyon. Salt Lake City: Brigham Young University, 1964.

Cost Analyses of Model Mines for Strip Mining of coal in the United States. Bureau of Mines Information Circular 8538 . Washington: Government Printing office, 1972.

* Covington, Robert E. "The Bituminous Sand of the Asphalt Ridge Area, Northeastern Utah." Guidebook to the Geology of the Uinta Basin. Ed. Otto G. Seal. Salt Lake CiEy: Intermountain Assn. Petroleum Geologists, 1957.

----. "Bituminous Sands and Viscous Crude Oils." Proceedings of the First Intermountain Symposium on Fossil Hydrocarbons. Eds. B.J. Pope, J.V. Harry and L.B. Lyon. Salt Lake City: Brigham Young University, 1964.

----. "Bituminous Sandstone and Limestone Deposits of Utah." Oil and Gas Possibilities of Utah, Re-evaluated. Ed. Arthur L. Crawford. Utah Geological and Mineralogical Survey Bulletin 54. Salt Lake City: Utah Geological and Mineralogical Survey, 1963.

----. "Bituminous Sandstones in the Uinta Basin." Guidebook to the Geology and Mineral Resources of the Uinta Basin, Utah's Hydrocarbon Storehouse, Ed. Edward F. Sabatka. Salt Lake City: Intermountain Assn. Petroleum Geologists, 1964 .

-.-. "Some Possible Applications of Thermal Recovery in Utah." Journal of Petroleum Technology, 17, No. 11, (1965), 12771284.

* ----. Thermal Recovery May Bring Industry's Quiet Revolution," Oil and Gas Journal, 62 , No. 47 (1964), 112-118.

Crawford, Arthur I., ed. Oil and Gas Possibilities of Utah, Re-evaluated. Utah Geological and Mineralogical Survey Bulletin 54, Salt Lake City: Utah Geological and Mineralogical Survey, 1963.

* Dane, C.H. "Stratigraphic and Facies Relationships of Upper Part of Green River Formation and Lower Part of Uinta Formation in Duchesne, Uintah, and Wasatch Counties, Utah." American Assn. Petroleum Geologists Bulletin, 38, (1954), $405-425$. 
Davitt, H.J. Economics. Lecture I from a 3-day course, "Oil Erom Tar Sands," Dr. F.W. Camp, Director, given at Calgary, Alberta, Canada, June 2-4, 1975 .

Dickenson, Douglas, Lois Johanson, and Roger D. Lee. EnergyRich Utah: Natural Resources and Proposed Developments. Salt Lake City: Department of Community Affairs, August, 1975.

Dor, A.A., et al. "Technical Problems in the Processing of Mixed Sand for Oil Recovery." Seventi World Petroleum Congress Proceedings, Vol. 3, Essex, England: Elsevier, $1967,615-623$.

Eardley, Armand J. Oil Seeps at Rozel Point. Utan Geological and Mineralogical Survey Special Studies 5. Salt Lake City: Utah Geological and Mineralogical Survey, 1963.

Energy Resources of the Uinta Basin, 1974. Utah Geological Assn. Publication 4. Salt Lake City: Utah Geological Assn., 1974.

Environmental Impact Analysis - A Proposed Pilot Fireflood Project, Oil Development Company of Utah, Lease Utan 17782-A, Gordon Flats Area, Wayne County, Utan. U.S. Geological Survey, Oil and Gas Conservation Division, Salt Lake City, Utah, 1974.

Farnand, J.R., H.M. Smith and I.E. Puddington. "Spherical Agglomeration of Solids in Liquid Suspension." Canadian Journal Chemical Engineering, 39 (1961), 94-7.

Gable, Charles M. , Edward A. Duncan, Jr., and E. Robert Freitas. Selective Solvent Extraction Plus Filtration of Tar Sands. Patent No. 3,475,318, U.S. Patent Office, Patented Oct. 28,1969 .

Garvin, Robert F. Stratigraphy and Economic Significance, Current Creek Formation, Northwest Uinta Basin, Utah. Utan Geological and Mineralogical Survey special Studies 27. Salt Lake City: Utah Geological and Mineralogical Survey, 1969.

Gi1l, Douglas. "Oil Sands Operations May Flourish in Alberta; They May Succeed in Utan on a Lesser Scale." Western Oil Reporter. November 1974, 47-50.

--- . "Utah and Athabasca Oil Sands Hold Huge Reserves." Western Oil Reporter. October 1974, 29-30.

"Utah Oil Sands Could Be A Solid Investment." Western Oil Reporter. December, 1974, pp. 27-29. 
Glassett, Joseph M. "Oil Recovery from Utah Tar Sands." Diss. Brigham Young University, March 13, 1975.

Gold, Otto. "Technical Problems in the Mining of Tar Sands." Seventh World Petroleum Congress Proceedings, Vol. 3. Essex, England: Elsevier, 1967. 605-614.

* Gray, G.R. "Conversion of Atnabasca Bitumen." American Institute of Chemical Engineers Symposium Series, 69, No. 127 (1973), 99-102.

Gwynn, John W. Instrumental Analysis of Tars and Their Correlations in Oil-Impregnated Sandstone Beds, Uintah and Grand counties, Utah. Utah Geological and Mineralogical Survey Special Studies 37. Salt Lake City: Utah Geological and Mineralogical Survey, 1971.

Hale, Lyle A. and Fred R. Van DeGraaff. "Cretaceous Stratigrapny and Facies Patterns, Northeastern Utah and Adjacent Areas." Guidebook to the Geology and Mineral Resources of the Uinta Basin, Utah's Hydrocarbon Storehouse, Ed. Edward F. Sabatka. Salt Lake City: Intermountain Assn. Petroleum Geologists, 1964 .

Harmston, Gordon E., Executive Director, Utah Department of Natural Resources. "Statement at the meeting of the American Water Resources Assn. "Utah Section." Salt Lake City, February 20, 1975.

Hills, L.V., ed. Oil Sands, Fuel of the Future. Calgary: Canadian Society of Petroleum Geologists, September, 1974.

Holmes, C.N., B.M. Page and P. Averitt. Geology of the Bituminous Sandstone Deposits Near Sunnyside, Carbon County, Utan. U.S. Geological Survey Oil and Gas Investigation Preliminary Map 86. Wasington: Government Printing OFfice, 1948 .

and B.M. Page. "Geology of the Bituminous Sandstone Deposits Near Sunnyside, Carbon County, Utah." Guidebook to the Geology and Economic Dependence of Eastern Utan Deposits. Ed. James Peterson, Salt Lake City: Intermountain Assn. Petroleum Geologists, 1956, 171-177.

Honkala, Rudolf A. Comp. Surface Mining and Mined Land Reclamation, A Selected Bibliography. Washington: The Old. West Regional Commission, October 1974 .

* Howard, J.V. "Thermal Recovery Comes of Age." World Oil, 160, No. 1 (1965), 95-104. 
Humphreys, R.D. "Oil from Alberta's Oil Sands." Chemical Engineering Progress, 70, No. 9 (1974), 66-70.

----. "Some Engineering Aspects of the G.C.O.S. Tar Sands Project," CIM Bulletin, December, 1974, 67-70.

Iammartino, Nocosias R. "Tar Sand Project Stuck." Chemical Engineering, 17 February 1975, 44-48.

Interdyne. "Solvent Recovery Systems." Letter to Joseph M. Glassett, May 31, 1975 .

Ion, D.C. "The Significance of World Petroleum Reserves." Seventh World of Petroleum Congress Proceedings, Vol. IB. Essex, England: Elsevier, 1967.

Innes, E.D. and J.V.D. Fear. "Canada's First Commercial Tar Sand Development." Seventh World Petroleum Congress Proceedings. Vol. 3, Essex, England: Elsevier, 1967.

Johnson, L.A., L.C. Marchant, and C.Q. Cupps. Properties of Utah Tar Sands - Asphalt Wash Area, P.R. Spring Deposit. Bureau of Mines Report of Investigations 8030 .

Washington: U.S. Bureau of Mines, 1975.

---. Properties of Utah Tar Sands - Seep Ridge Area, P.R. Spring Deposit. Bureau of Mines Report of Investigations 8003. Washington: U.S. Bureau of Mines, 1975.

Kaminsky, V.P. and Elmer Nagy. "Athabasca Oil Sands: Recovery Methods." Fossil Hydrocarbon and Mineral Processing. American Institute of Chemical Engineers Symposium Series, 64 , No. 85 (1968).

Karnofsky, George. "The Rotocel Extractor," Chemical Engineering, August, 1950, 108-10.

Kayser, Robert B. Bituminous Sandstone Deposits of Asphalt Ridge. Utan Geological and Mineralogical Survey Special Studies 19. Salt Lake City: Utah Geological and Mineralogical Survey, 1966.

Kemp, Kenneth A. "Computerized System Analyses Dragline Performance - Prints Out Data." Coal Age, September 1974.

* Kinney, D.M. Geology of the Uinta River - Brush Creek Area, Duchesne, and Uintah Counties Utah. U.S. Geological Survey Bulletin 1007. Washington: Government Printing office, 1955. 
Legislature, 4lst, of the state of Utah

"Access Roads for Energy Resource Developments," S.J.R.

"Ad Valorem Taxation of Non-Metalliferous Minerals," S.J.R.

"Application of Water to Beneficial Use," S.B. No. 290.

"Building Schoolhouses," S.B. No. 257.

"Definition of Mining," S.B. No. 5.

"Designation of State Highways," S.B. No. 260.

"Mined Land Reclamation," H.B. No. 323.

"Prepaid Use Tax," S.B. No. 259.

"Prepaid Sales Tax," S.B. No. 258.

"Resource Development Act," S.B. No. 256.

Salt Lake City, 1975.

Leske, Alan E. The Future of Open Pit Mining for the Alberta

Oil Sands. Unpub. paper, Dept. of Civil and Mining

Engineering, University of Minnesota, 1967.

Linden, Henry R., President, Institute of Gas Technology, Statement of, In An Appearance Before the Subcommittee on Energy Research and Water Resources Committee on Interior and Insular Affairs, U.S. Senate, March 3, I975. Washington: Government Printing office, 1975 .

Linville, Bill and J.D. Spencer. Bureau of Mines Energy Program, 1972. U.S. Bureau of Mines Information Circular 8612. Washington: Government Printing Office, 1973.

Lohman, S.W. The Geologic Story of Canyonlands National Park. Geological survey Bulletin 1327. Washington: Government Printing office, 1974 .

Lowe, R.M. Status of Tar Sand Exploitation in the U.S. Paper presented at AICHE Convention, Los Angeles, Nov. 20, 1975.

Lyon, Lloyd B. "Primary Extraction, Conversion and Upgrading Hydrogen - Deficient Fossil Hydrocarbons." Proceedings of the First Intermountain Symposium on Fossil HyaroCarbons. Eds. B.J. Pope, J.V. Harry and L.B. LYon. Salt Lake City: Brigham Young University, 1964.

Maberry, J.O. Sedimentary Features of the Blackhawk Formation (Cretaceous) in the Sunnyside District, Carbon County, Utah. U.S. Geological Survey Professional Paper 688, Washington: Government Printing Office, 1971.

Marchant, I.C., C.S. Land and C.Q. Cupps. Experimental Approach to In-situ Oil Recovery from Tar Sands. Bureau of Mines Report, presented at Albuquerque, N.M. , March 1975. 
Marchant, L.C., L.A. Johnson and C.Q. Cupps. Properties of Utah Tar Sands, Threemile Canyon Area, P.R. Spring Deposit. Bureau of Mines Report of Investigations 7923. Washington: Government Printing Office, 1974.

Markley, Klare S. and Warren H. Goss. "Processing by Means of Continuous Solvent Extractors." Soybean Chemistry and Technology. Chemical Publishing Co., Inc. 1944.

Mathematica/Ford, Bacon and Davis. Overburden Handling Checklist, November 15, 1974. Salt Lake City: Mathematica, 1974.

Mathison, Ruby. Synthetic Fuel Research - A Bibliography. Arlington: American Gas Assn., 1973.

Mauger, R.I., R.G. Kayser and J.W. Gwynn. A Sulphur Isotopic Study of Uinta Basin Hydrocarbons. Utah Geological and Mineralogical Survey special Studies 4l. Salt Lake City: Utah Geological and Mineralogical Survey, 1973.

McConville, L.B. "The Athabasca Tar Sands," Mining Engineering, January, 1975, 19-38.

McDermott, John. Iiquid Fuels from Oil Shale and Tar Sands 1972. Park Ridge, N.J.: Noyes Data Corporation, 1972 .

Moschopedis, S.E. and J.G. Speight. "Oxidative Degradation of Athabasca Asphaltenes." Fuel, 50, No. 2 (1971), 211-17.

----. "Water Soluble Derivatives of Athabasca Asphaltenes." Fuel, 50, No. 1 (1971) 34-40.

Mullens, M.C. and A.E. Roberts. Selected Annotated Bibliography on Asphalt-Bearing Rocks of the United States and Canada to 1970. Geological Survey Bulletin 1352. Washington: Government Printing office, 1972.

Murany, E.E. "Wasatch Formation of the Uinta Basin." Guidebook to the Geology and Mineral Resources of the Uinta Basin Utah's Hydrocarbon Storehouse. Ed. Edward F. Sabatka. SaIt Lake City: Intermountain Assn. Petroleum Geologists, 1964 .

"Oil From Tar Sands," Course of Center for Professional Advancement, Dr. F.W. Camp, Course Director, Calgary, Alberta, June 2-4, 1975.

Peterson, Parley R. and Howard R. Ritzma. Informational Core Drilling in Utah's Oil-Impregnated Sandstone Deposits, Southeast Uinta Basin, Uintah County, Utah. Utah Geological and Mineralogical survey Report of Investigations 88 . Salt Lake City: Utah Geological and Mineralogical Survey, 1974. 
----. Lithologic Logs and Correlation of Coreholes, P.R. spring and Hill Creek Oil-Impregnated Sandstone Deposits, Uintah County, Utah. Utah Geological and Mineral Survey Report of Investigations 100. Salt Lake City: Utah Geological and Mineral Survey, 1975.

and Howard Ritzma. "Oil-Impregnated Sandstone, Thistle Area, Utah County, Utah." Plateau-Basin and Range Transition Zone, Central utah. Utah Geological Assn. Publication 2. Salt lake City: Utah Geological Assn., 1972 .

Phizackerley, P.H. and L.O. Scott. "Major Tar Sand Deposits of the World." Seventh World Petroleum Congress Proceedings, Vol. 3. Essex, England: Elsevier, 1967.

* Picard, M. Duane. "Green River and Lower Uinta Formations Subsurface Stratigraphic Changes in Central and Eastern Uinta Basin, Utah." Guidebook to the Geology of the Uinta Basin. Ed. Otto G. Seal. SaIt Lake City: Intermountain Assn. Petroleum Geologists, 1957.

---- and Andersen. "Paleocurrent Analysis and orientation of Sandstone Bodies, Duchesne River Formation." Utai Geology, 2 , No. 1 (1975).

----. Petrographic Criteria for Recognition of Lacustrine and Fluvial Sandstone, P.R. Spring Oil-Impregnated Sandstone Area, Southeast Uinta Basin, Utah. Utah Geological and Mineralogical and survey Special studies 36. Salt Lake City: Utah Geological and Mineralogical Survey, 1971 .

and I.R. High, Jr. Sedimentology of Oil-Impregnated, Lacustrin and Fluvial Sandstone, P.R. Spring Area, Southeast Uinta Basin, Utah. Utah Geological and Mineralogical Survey Special Studies 33. Salt Lake City: Utah Geological and Mineralogical Survey, 1970.

Pruitt, Robert G., Jr. "Bituminous Sands and Some Legal Aspects of Leasing." Proceedings of the First Intermountain Symposium on Fossil Hydrocarbons. Eds. B.J. Pope, J.V. Harry, I.B. Lyon. Salt Lake City: Brigham Young University, 1964 .

----. "Natural Oil vs. Converted Oil - A Lawyer's View." Interstate Oil Compact Commission Committee Bulletin, 11, No. 2 (1969), 22-23. 
Ral1, Cleo G. and D.B. Taliaferro. A Method for Determining Simultaneously the Oil and water Saturations of Oil Sands. Bureau of Mines Report of Investigations 4004 , Washington: Government Printing Office, 1946.

----, N.C. Hamontre and D.B. Taliaferro. Determination of Porosity by a Bureau of Mines Method: A List of Porosities of Oil sands. Bureau of Mines Report of Investigations 5025. Washington: Government Printing Office, 1954.

Rammler, R.W. "The Retorting of Coal, Oil Shale and Tar Sand by Means of Circulated, Fine-Grained Heat Carriers as the Preliminary Stage in the Production of Synthetic Crude oil." Quarterly of the Colorado School of Mines, Vol. 65, No. 4, Golden: Colorado School of Mines, 1970 .

Rickles, Robert N. "Iiquid-Solid Extraction." Chemical Engineering, March 15, 1965, 157-164.

Ritzma, Howard R. "Commercial Aspects of Utah's Oil Impregnated Sandstone Deposits." Paper presented to joint session of Interstate oil Compact Commission, New Orleans, December 3,1973 .

----. "Exploration and Development of Oil shale and OilImpregnated Rock, 1970-1975." Paper prepared for presentation to American Assn. Petroleum Geologists, Mineral Economics Symposium II, Annual Meeting, Denver, Colorado, 1972 .

---- and H.H. Doelling. Mineral Resources, San Juan County, Utah, and Adjacent Areas. Utah Geological and Mineralogical Survey Special Studies 24, Salt Lake City: Utah Geological and Mineralogical Survey, 1969.

----. "Petroleum Potential of Utah." Paper presented to American Assn. Petroleum Geologists, Rocky Mountain Section, Albuquerque, New Mexico, February 26, 1969.

and W.P. Hewitt. "Proposal for Informational core Drilling in Utah's Tar Sand Deposits." Letter to Mr. Sheldon Wimpfden, April 10, 1972 .

----. Oil-Impregnated Rock Deposits of Utah. Utah Geological and Mineralogical Survey Map 33. Salt Lake City: Utah Geological and Mineralogical Survey, 1974.

----. "Oil-Impregnated Sandstone Deposits of Utah." Interstate Oil Compact Commission Committee Bulletin, 9, No. 2 (1967), $\overline{87}=98$. 
----. "Oil-Impregnated Sandstone Deposits of Utah - A Progress Report." Interstate oil Compact Commission Committee Bulletin, 11, No. 2(1969), 24-34.

----. "Utah's Oil-Impregnated Sandstone Deposits, A Giant Undeveloped Resource." Paper presented to joint session in Interstate Oil Compact Commission, New Orleans, 3 December 1973.

----. Utah's Tar Sand Resource: Geology, Politics, and Economics. Paper No. lo7a AICHE, Los Angeles, California, November $20,1975$.

Rothberg, Paul F. Public Policy Issues Associated with Development of the U.S. Tar Sands. Washington: Iibrary of Congress, Congressional Research Service, 1974.

* Sanborn, A.F. and J.C. Goodwin. "Green River Formation at Raven Ridge, Uintah County, Utah." Mountain Geologist, 2 , No. $3(1965), 109-114$.

Sharbaugh, H. Robert. "The Case for Canadian - U.S. Cooperation in Energy." Our Sun, 40, No. 1 (1975), 16-18.

Shea, G.B. and R.V. Higgins. "Laboratory Hot-Water Separation Tests," Separation and Utilization Studies of Bitumens from Bituminous Sandstones of the Vernal and sunnyside, Utah, Deposits. Bureau of Mines Report of Investigations 4871. Washington: Government Printing office, 1952.

----. Laboratory Study of the Hot Water Process for Separating Hy drocarbons from surface Deposits of Bituminous sandstones Near Edna, California. Bureau of Mines Report of Investigation 4246. Washington: Government Printing Office, 1948.

Sohio Petroleum Company. "Application of the Sohio Petroleum Company for Permission to Commence Mining Operations for the Removal of Bituminous Sands, Uintah County, Utah." Before the Board of $\mathrm{Oil}$ and Gas Conservation, Department of Natural Resources in and for the State of Utah, August 28, 1974.

---.-. "Notice of Intention to Commence Mining Operations to $\mathrm{Mr}$. Cleon Feight, Director, Board of Oil and Gas Conservation, Department of Natural Resources, State of Utah." July 1, 1974.

---- Proposed Plan for Mining and Processing Operations, Bituminous Sañd Deposits, Asphalt Ridge Area, Uintah County, Utah, witn Particular Reference to the Environmental Effects of the Operations. OkIahoma City: Sohio Petroleum Company, 1974. 
Spencer, G.B., W.E. Eckard, and F.S. Johnson. "Domestic Tar Sands and Potential Recovery Methods - A Review."

Interstate Oil Compact Commission Committee Bulletin, II, No. 2 (1969), 5-12.

* Spieker, E.M. Bituminous Sandstone Near Vernal, Utah. U.S. Geological Survey Bulletin 822-C. Washington: Government Printing Office, 1930.

* Spraggins, F.K. "Fourth Tar Sands Plant Proposed at Athabasca." Oil and Gas Journal, 72, No. $4(1974), 86$.

----. "Mining at Athabasca - A New Approach to Oil Production." Journal of Petroleum Technology, 19, No. 10 (1967), 1337-43.

Stefanko, R. , R.V. Famani, and M.R. Ferko, An Analysis of Strip Mining Methods and Equipment Selection. Office of Coal Research, Research and Development Report 61 . Washington: Government Printing Office, 1973.

"Summary of Industry Oil Shale Environmental Studies and Selected Bibliography of oil Shale Environmental References."

Denver: Rocky Mountain Oil and Gas Assn., March, 1975.

Tan, Romeo and Rand Thurgood. Solvent Extraction Process for Removal of Bitumen from Tar Sand. Paper prepared for Chemical Engineering 683, Advanced Plant Design, Brigham Young University, June 19, 1975.

"Tar Sand." Energy Perspectives. Columbus: Battelle Memorial Institute, No. 15, October, 1974.

Tar Sands, Hearing Before the Subcommittee on Minerals, Materials, and Fuels of the committee on Interior and Insular Affairs, U.S. Senate, 9lst Congress. Washington: Government Printing Office, 1970.

"There's Plenty of Coal - What's Behind the Holdup? U.S. News and World Report, December 24, 1973, 59-60.

Thorpe, Richard, Preliminary Design: Tar Sand Processing Plant. Paper prepared for Chemical Engineering 683, Advanced Plant Design, Brigham Young University, June 26, 1975.

"Ultrasonics for Oil Sands?" Oilweek, February 10, 1975, 4.

* Untermann, G.B. and B.R. Untermann. Geology of Uintah County, Utah. Utah Geological and Mineralogical Survey BuIletin 72 . SaIt Lake City: Utah Geological and Mineralogical Survey, 1964. 
U.S. Bureau of Mines. "Application of the U.S. Bureau of Mines Laramie Energy Research Center, for an Order permitting a Research Field Experiment to Employ the Reverse Combustion Process for Recovery of Oil from Tar Sands or Oil-Impregnated Rock Deposits, Asphalt Ridge Area, Uintah County, Utah. Before the Board of Oil and Gas Conservation Department of Natural Resources in and for the State of Utah, November 20, $1974 . "$

Upper Colorado Region Comprehensive Framework Study, Main Report. Prepared by the Upper Colorado Staff and Work Group Chairman of the Upper Colorado Region State-Federal Inter-Agency Group for the Pacific Southwest Inter-Agency Committee Water Resources Council, June, 1971.

Utah Mining Assn. Utah's Mining Industry, 3rd ed. Salt Lake City: Utah Mining Assn., 1967.

Walton, P.T. "Cretaceous Stratigraphy of the Uinta Basin." Guidebook to the Geology of the Uinta Basin. Ed. Edward F. Sabatka. Salt Lake City: Intermountain Assn., Petroleum Geologists, 1957.

* ----. "Geology of Cretaceous of the Uinta Basin, Utah." Geological Society of America Bulletin, Vol. 55 (1944), $91-130$.

Warren, C.W. Index to the Salt Lake Mining Review, 1899-1928. Utah Geological and Mineralogical Survey Bulletin 91. Salt Lake City: Utah Geological Mineralogical Survey, 1971 .

Warren, F.H. and M.I. Goldman. "Environmental Impact of Future Energy Sources." Chemical Engineering, Deskbook Issue. October $21,1974, \overline{47-51 .}$

Wenger, W.J., R.L. Hubbard, and M.L. Whisman. "Analytical Data on Asphalt Properties and Cracked Products of the Separated Bitumens." Separation and Utilization Studies of Bitumens from Bituminous Sandstones of the Vernal and Sunnyside, Utah, Deposits. Bureau of Mines Report of Investigations 4871. Washington: Government Printing Office, 1952.

West, Robert $C$. Non-Aqueous Process for the Recovery of Bitumen from Tar sands. Patent No. 3,13I, I4I, U.S. Patent Office, Patented ApriI 28, 1964.

Western States Water Council. Western States Water Requirements for Energy Development to 1990. SaIt Lake City: Western states Water Council, 1974. 
Whiting, Jerry M. "Planning for Production of Synthetic Hydrocarbons Fuels." Mining Congress Journal, 60, No. $2(1974), 50-60$.

Wiley, Dennis R. Petrology of Bituminous Sandstones in the Green River Formation, Southeastern Uinta Basin, Utah. M.S. Thesis, University of Utah, 1967.

Wilson, M.T., R.H. Langford, and Ted Arnow. "Water Resources." Mineral and Water Resources of Utah. Utah Geological and Mineralogical Survey Bulletin 73. Salt Lake City: Utah Geological and Mineralogical Survey, 1969.

Wood, R.E. and H.R. Ritzma. Analyses of Oil Extracted from Oil-Impregnated Sandstone Deposits in Utah. Utah Geological and Mineralogical Survey Special studies 39 . Salt Lake City: Utah Geological and Mineralogical Survey, 1972.

* Copies available but not in possession of Eyring Research Institute. All other copies are in possession. 